\author{
Monograph \\ urn:1sid:zoobank.org:pub:9823AAD7-1113-434B-9882-1CF885DE7CED
}

\title{
Redefinition of the sexstrigatus group of Lasioglossum (Hemihalictus) Cockerell, 1897 (Hymenoptera, Apoidea, Halictidae), with a revision of Japanese species
}

\author{
Ryuki MURAO \\ Regional Environmental Planning Co., Ltd, 1-10-12, Muromi, Sawara-ku, Fukuoka, 814-0015 Japan. \\ Email: r.murao@mbr.nifty.com \\ urn:1sid:zoobank.org:author:7E665839-6675-4365-A7EA-169D4E4DA008
}

\begin{abstract}
I propose a redefinition of the sexstrigatus group of Lasioglossum (Hemihalictus) Cockerell, 1897, including a phylogenetic analysis. This group is characterised by a combination of the following 12 characteristics: male antenna short, not attaining to metasoma, male labrum with distal process and well-developed basal elevation, male head with genal process as variation, female mesepisternum reticulate-punctate on lower area, mesepisternum without tubercle in both sexes, female metasomal terga with distinct fimbriae on posterior margin, male S8 with well-developed median process, gonobase ventral arm of male genitalia connected with each other at upper ends, gonocoxite of male genitalia smooth, gonostylus of male genitalia small and simple, bud-like, and the ventral retrorse lobe of male genitalia not attaining to gonobase. The Japanese species of the sexstrigatus group are revised. Thirteen species in total are recognised, including three new species: Lasioglossum (Hemihalictus) ikudomei sp. nov., L. (H.) spectrum sp. nov., and L. (H.) subsimplicior sp. nov. Lasioglossum (Hemihalictus) perplexans (Cockerell, 1925) is synonymised under L. (H.) kiautschouense (Strand, 1910). A key to the Japanese species is provided. Bionomical data, such as flight and flower records or habitat, are reported for some species. The distributions of all species are mapped. DNA sequences including a part of the barcode region are given for L. (H.) kiautschouense, L. (H.) ohei Hirashima \& Sakagami, 1966, L. (H.) speculinum (Cockerell, 1925), L. (H.) spectrum sp. nov., L. (H.) subsimplicior sp. nov., and L. (H.) taeniolellum (Vachal, 1903).
\end{abstract}

Keywords. Halictidae, Lasioglossum, sexstrigatus group, Eastern Asia.

Murao R. 2021. Redefinition of the sexstrigatus group of Lasioglossum (Hemihalictus) Cockerell, 1897 (Hymenoptera, Apoidea, Halictidae), with a revision of Japanese species. European Journal of Taxonomy 763 : 1-74. https://doi.org/10.5852/ejt.2021.763.1463

\section{Introduction}

Hemihalictus Cockerell, 1897 is a subgenus of Lasioglossum Curtis, 1833 (Halictidae Thomson, 1869, Halictinae Thomson, 1869), with approximately 250 species worldwide (Ascher \& Pickering 2020). Lasioglossum (Hemihalictus) was considered monotypic (Michener 2007) until it was reclassified by a recent study (Gibbs et al. 2013) as a group that includes L. (Hemihalictus) s. str., L. (Sudila) Cameron, 1898, and the black L. (Dialictus) Robertson, 1902, as classified by Michener (2007). The 
composition of $L$. (Hemihalictus) sensu Gibbs et al. (2013) considerably differs from the systematics of Palearctic researchers (e.g., Ebmer 1976, 1997, 2000; Ebmer \& Sakagami 1985; Ebmer et al. 1994; Pesenko 2007a). In Ebmer's system, the Palearctic species of L. (Hemihalictus) sensu Gibbs et al. (2013) correspond to the carinaless L. (Evylaeus) Robertson, 1902. In the system of Pesenko (2007a), Evylaeus is treated as a valid genus with 12 subgenera (E. (Limbevylaeus) Pesenko, 2007, E. (Crassevylaeus) Pesenko, 2007, E. (Laevinodilaeus) Pesenko, 2007, E. (Pallidevylaeus) Pesenko, 2007, E. (Pauphalictus) Warncke, 1982, E. (Prosopalictus) Strand, 1913, E. (Puncthalictus) Warncke, 1975, E. (Marghalictus) Warncke, 1975, E. (Microhalictus) Warncke, 1975, E. (Nitidiusculaeus) Pesenko, 2007, E. (Rostrohalictus) Warncke, 1975, E. (Truncevylaeus) Pesenko, 2007) corresponding to L. (Hemihalictus) sensu Gibbs et al. (2013). In the present study, I follow the recent systematics of Lasioglossum proposed by Gibbs et al. (2013). Many species groups have been recognised in the Palearctic L. (Hemihalictus) by various researchers (e.g., Blüthgen 1934; Ebmer 1975, 1986; Warncke 1975; Ebmer \& Sakagami 1985; Sakagami \& Ebmer 1996). At present, these species groups have been reclassified by Pesenko (2007a) into the following 12 groups: 1) clypearis group, 2) crassepunctatum group, 3) laevinode group, 4) limbellum group, 5) longirostre group, 6) nitidiusculum group, 7) marginellum group, 8) pallidum group, 9) pauperatum group, 10) semilucens group, 11) sexstrigatus group, and 12) villosulum group. These groups are treated as being of subgeneric status in Pesenko (2007a). The species of L. (Hemihalictus) are morphologically similar to each other, therefore, even in the Pesenko's system, there remains ambiguity in the definition of each group.

One of these, the sexstrigatus group, includes over 30 species and is diverse in eastern Asia (Pesenko 2007b; Murao et al. 2010). This group is mainly characterised by the female metasomal terga with distinct fimbriae on the lateral-apical margin and the male head with a size-linked gigantism with genal process (Sakagami \& Ebmer 1996). However, some species in the group do not necessarily share these characteristics (Murao 2017a). This group is also quite difficult to identify at the species level in Lasioglossum because identification is often based on subtle morphological differences (e.g., Sakagami \& Ebmer 1996). A few species are known as solitary or communal (Sakagami et al. 1966; Sakagami 1992), but no eusocial species are known. Some species often dominate in the Japanese bee fauna when considering the number of individuals (Ikudome 1995; Iwata 1997; Minagi et al. 2000; Negoro 2001a, 2001b; Maeta et al. 2003; Gôukon 2006; Hisamatsu \& Yamane 2006; Hisamatsu 2011, 2017; Murao, Murase \& Iwata unpublished).

Twenty-two species of the sexstrigatus group have been partially described or recorded in Japan by various researchers (Smith 1873; Vachal 1903; Strand 1910; Blüthgen 1925; Sakagami et al. 1966; Usui et al. 1976; Takahashi \& Sakagami 1993; Ebmer et al. 1994; Sakagami \& Tadauchi 1995; Sakagami \& Ebmer 1996; Murao et al. 2010; Murao 2012).

As a first step in the taxonomic study of the sexstrigatus group in Asia, this study revises the definition of this group, including a phylogenetic analysis based on the morphological characteristics and the Japanese fauna.

\section{Material and methods}

\section{Collection}

This study is based on the specimens deposited in the following institutions and personal collections, which are referred to using the following abbreviations:

$\begin{array}{ll}\text { AETU } & =\text { Applied Entomological Laboratory, Tokai University, Kumamoto, Japan } \\ \text { AMNH } & =\text { American Museum of Natural History, New York, USA } \\ \text { cGou } & =\text { private collection of Mr Katsuo Goukon, Miyagi, Japan } \\ \text { cMur } & =\text { the first author's private collection, Fukuoka, Japan }\end{array}$ 


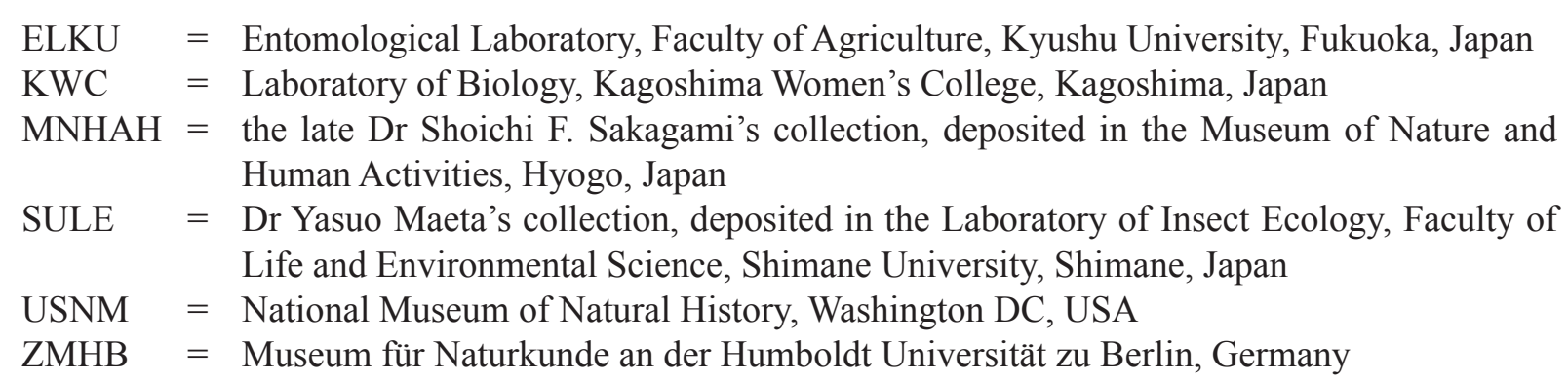

\section{Terminology}

Terminology and style used in the description follows Murao et al. (2015b). Abbreviations used in the text are as follows:

$\mathrm{AOD}=$ antennocular distance (shortest distance between outer margin of antennal socket and inner margin of compound eye)

$\mathrm{BL}=$ body length (from antennal base to tip of pygidial plate)

$\mathrm{CAL}=$ clypealveolar distance (between lower margin of antennal socket and lower margin of supraclypeus in frontal view)

$\mathrm{CPL}=$ clypeal length (between upper and lower margins of clypeus in frontal view)

$\mathrm{EL}=$ eye length

$\mathrm{EW}=$ eye width (maximum length and width of the compound eye)

$\mathrm{Fn}=\mathrm{n}^{\text {th }}$ antennal flagellomere

$\mathrm{FnL}=$ length of $\mathrm{n}^{\text {th }}$ flagellomere (measured along the ventral surface)

$\mathrm{FnW}=$ width of $\mathrm{n}^{\text {th }}$ flagellomere (measured from dorsal and ventral surfaces of flagellomere)

$\mathrm{GW}=$ genal width (maximum width of the genal area when seen in lateral view)

$\mathrm{HL}=$ head length (from top of vertex to lower margin of clypeus)

HW = head width (between outer margins of compound eyes in frontal view)

IAD = interantennal distance (between inner margins of antennal sockets)

IOD = interocellar distance (between lateral ocelli)

IS = interspace between punctures (e.g., IS $0.5 \mathrm{~d}$ means $1 / 2$ of the diameter of a puncture)

LOD $=$ lower interorbital distance

$\mathrm{MNL}=$ metanotal length

MOD $=$ maximum interorbital distance

MPL $=$ metapostnotal length

$\mathrm{MsW}=$ maximum mesosomal width

$\mathrm{MtW}=$ maximum metasomal width

OCD = ocelloccipital distance (shortest distance between margins of lateral ocellus and vertex when seen in upper view)

OOD $=$ ocellocular distance (shortest distance between lateral ocellus and inner margin of compound eye)

$\mathrm{PP}=$ punctures

SCL = mesoscutellar length

$\mathrm{Sn}=\mathrm{n}^{\text {th }}$ metasomal sternum

SPL = scape length (a straight line from base to tip of scape)

$\mathrm{Tn}=\mathrm{n}^{\text {th }}$ metasomal tergum

$\mathrm{UOD}=$ upper interorbital distance

$\mathrm{WL}=$ wing length (length of fore wing from the apical point to the base including tegula)

\section{Flower records}

Flower records visited by each species are based on specimen label data. The scientific names of flowering plants visited by bees are cited from Yonekura \& Kajita (2003-). 


\section{Distribution maps}

Distribution maps were made by QGIS ver. 3.6 (QGIS Development Team 2020) using map data download from Natural Earth (https://www.naturalearthdata.com/). The point data for each map are based mainly on the examined specimens, but also partially on the following publications: Sakagami \& Tadauchi (1995), Sakagami \& Ebmer (1996), Goubara \& Maeta (2002), Goubara et al. (2002), Haneda \& Tano (2003), Ikudome (2005), Gôukon (2006), Yamane \& Ikudome (2008), Ikudome \& Yamane (2009), Fukasawa \& Miyano (2010), Murao (2015), and Hiraiwa \& Ushimaru (2017). Locality data which lacked both latitude and longitude were geocoded by GeoNames (https://www.geonames.org/).

\section{Cladistic analysis}

To test monophyly of the sexstrigatus group, I selected two to 16 species from each of 10 species groups of Lasioglossum (Hemihalictus) as the ingroup and two species of L. (Dialictus) as an outgroup (Appendix 1). A total of 32 morphological characters were coded using MESQUITE ver. 3.61 (Maddison \& Maddison 2019) (Appendix 2). Characters are coded as ' 0 ', ' 1 ', ' '2' or ' 3 ' and the data matrix is shown in Appendix 3. A cladistic analysis was performed using TNT ver. 1.1 (Goloboff et al. 2008) traditional heuristic search that generated 1000 Wagner trees with random addition sequence. Symmetric resampling was performed using default settings for 1000 replicates. Unambiguous character state changes were mapped on the most parsimonious trees using WINCLADA ver. 1.00.88 (Nixon 2002).

\section{DNA analyis}

DNA extraction and PCR were conducted at the Kyushu University Museum (Fukuoka, Japan). DNA was extracted using a DNeasy Blood and Tissue kit (Qiagen, Tokyo, Japan) following the manufacture's instructions. A $707 \mathrm{bp}$ including a part of DNA barcode region of the cytochrome oxidase subunit I (COI) gene fragment of mtDNA was amplified (using the primers COI_pF2 and COI_2437d), purified, and electrophoresed following the methods decribed by Murao et al. $(2015 \mathrm{c})$. DNA sequencing was outsourced to the FASMAC Co., Ltd (Kanagawa, Japan). The sequences analyzed in the present study are deposited in GenBank through the DNA Database of Japan (DDBJ). Appendix 4 lists the GenBank accession numbers used in the present paper. Pairwise sequence divergences within each specis of sexstrigatus group were calculated using Kimura 2-parameter distance (Kimura 1980). The analyses were conducted using MEGA5 (Tamura et al. 2011).

\section{Results}

\section{Phylogenetic analysis}

The phylogenetic analysis resulted in a most parsimonious tree $(\mathrm{L}=137, \mathrm{Ci}=33, \mathrm{Ri}=57)$ (Fig. 1). In the present analysis, monophyly of the sexstrigatus group sensu Sakagami \& Ebmer (1996), Pesenko (2007a), and Murao et al. (2010) is not supported and members are split into at least two clades: the sexstrigatus clade, comprising Lasioglossum (Hemihalictus) amamiense Ebmer \& Sakagami, 1994, L. (H.) frigidum Sakagami \& Ebmer, 1996, L. (H.) ohei Hirashima \& Sakagami, 1966, L. (H.) sexstrigatus (Schenck, 1869), L. (H.) simplicior (Cockerell, 1931), L. (H.) smilodon Ebmer \& Sakagami, 1994, L. (H.) spectrum sp. nov., L. (H.) sphecodicolor Sakagami \& Tadauchi, 1995, and L. (H.) taeniolellum (Vachal, 1903) and the japonicum clade, comprising L. (H.) canaliculatum Murao, 2010, L. (H.) donanense Murao, 2010, L. (H.) japonicum (Dalla Torre, 1896), L. (H.) urumaense Murao, 2010, L. (H.) yonaguniense Murao, 2010, and L. (H.) zipangu Ebmer \& Sakagami, 1994. The sexstrigatus clade is defined by six homoplasious synapomorphies: 1) the male head with genal process (variable with allometry) (3:0); $2)$ the distal process of male labrum present $(13: 0) ; 3)$ the female metasomal terga with fimbriae on apical margin (21:0) (secondarily lost in L. (H.) sphecodicolor); 4) the male S8 with developed median process $(23: 0)$; 5) gonobase ventral arms of male genitalia connected with each other at upper ends (24:0); and 6) the ventral retrorse lobe of male genitalia not reaching gonobase (28:1). I here propose a 


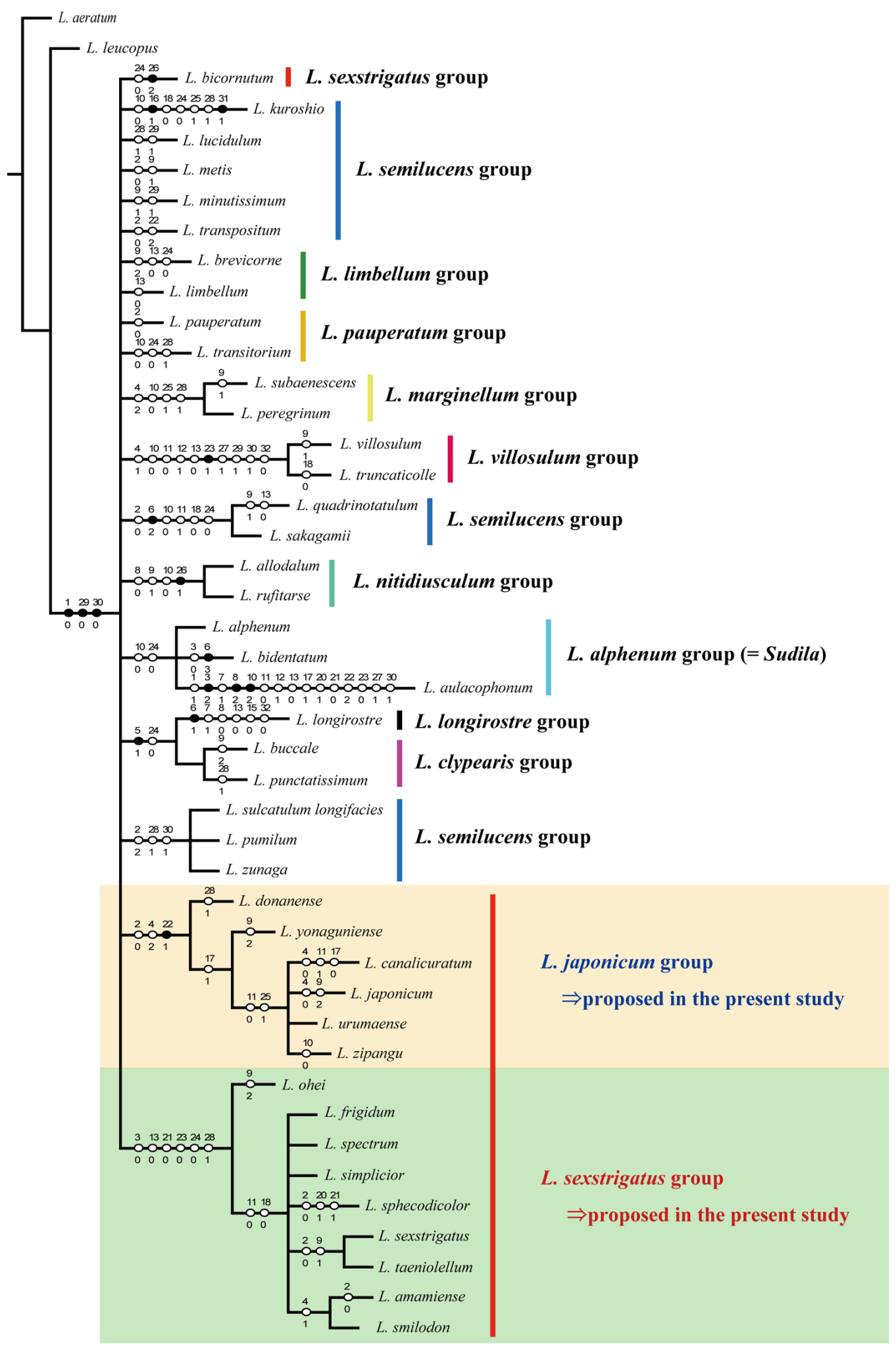

$\Rightarrow$ Red bar: L. sexstrigatus group sensu Sakagami \& Ebmer (1996),

Pesenko (2007a), Murao et al. (2010)

Fig. 1. A most parsimonious tree resulting from analysis of the matrix in Appendix 3. Black circles indicate non-homoplacious changes, white circles indicate homoplasious change. For characters and character states see Appendix 2. 
revised classification that the sexstrigatus group is restricted to species sharing the characteristics of the sexstrigatus clade.

The japonicum clade is also proposed here as a new species group (as the japonicum group) because its monophyly is supported by three synapomorphies, one of which, male S4-S5 latero-posteriorly with thin hair tufts $(22: 1)$ is non-homoplasious. For the remaining nine species groups, monophyly is supported for the following groups in the present analysis: the alphenum group (= L. (Sudila)), nitidiusculum group, marginellum group, villosulum group, and the clypearis + longirostre groups clade.

\section{Taxonomy}

Class Insecta Linnaeus, 1758

Order Hymenoptera Linnaeus, 1758

Superfamily Apoidea Latreille, 1802

Family Halictidae Thomson, 1869

Subfamily Halictinae Thomson, 1869

Tribe Halictini Thomson, 1869

Genus Lasioglossum Curtis, 1833

\section{Lasioglossum (Hemihalictus) Cockerell, 1897}

Hemihalictus Cockerell, 1897: 288 (also published as new by Cockerell 1898) (type species: Panurgus lustrans Cockerell, 1897, by original designation).

Sudila Cameron, 1898: 52 (type species: Sudila bidentata Cameron, 1898, by designation of Sandhouse 1943).

Prosopalictus Strand, 1913: 26 (type species: Prosopalictus micans Strand, 1913, by original designation and monotypy).

Ceylonicola Friese, 1918: 501 (type species: Ceylonicola atra Friese, 1918=Sudila bidentata Cameron, 1898, by designation of Sandhouse 1943).

Halictus (Microhalictus) Warncke, 1975: 85 (type species: Melitta minutissima Kirby, 1802, by original designation).

Halictus (Puncthalictus) Warncke, 1975: 87 (type species: Hylaeus punctatissimus Schenck, 1853, by original designation).

Halictus (Rostrohalictus) Warncke, 1975: 88 (type species: Halictus longirostris Morawitz, 1876, by original designation and monotypy).

Halictus (Marghalictus) Warncke, 1975: 95 (type species: Hylaeus marginellus Schenck, 1853, by original designation).

Lasioglossum (Sellalictus) Pauly, 1980: 120 (type species: Halictus latesellatus Cockerell, 1937, by original designation).

Halictus (Pauphalictus) Warncke, 1981: 87 (type species: Halictus pauperatus Brullé, 1832, by original designation).

Lasioglossum (Mediocralictus) Pauly, 1984: 143 (type species: Halictus mediocris Benoist, 1962, by original designation).

Evylaeus (Limbevylaeus) Pesenko, 2007a: 20 (type species: Halictus limbellus Morawitz, 1876, by original designation).

Evylaeus (Crassevylaeus) Pesenko, 2007a: 20 (type species: Halictus crassepunctatus Blüthgen, 1923, by original designation and monotypy).

Evylaeus (Laevinodilaeus) Pesenko, 2007a: 20 (type species: Halictus laevinodis Morawitz, 1876, by original designation and monotype).

Evylaeus (Pallidevylaeus) Pesenko, 2007a: 23 (type species: Nomioides pallida Radoszkowski, 1888, by original designation and monotypy). 
Evylaeus (Nitidiusculaeus) Pesenko, 2007a: 24 (type species: Melitta nitidiuscula Kirby, 1802, by original designation).

Evylaeus (Truncevylaeus) Pesenko, 2007a: 24 (type species: Halictus truncaticollis Morawitz, 1877, by original designation).

\section{Diagnosis}

In eastern Asia, the species of Hemihalictus series are classified into four subgenera (Acanthalictus, Dialictus, Hemihalictus, and Sphecodogastra). The subgenus Hemihalictus is separated from the other three subgenera by the following key:

1. Lower margin of male clypeus deflected forward; female labrum without basal elevation; basal elevation of male labrum stongly swollen, with longitudinal furrow; female mandible with two preapical teeth; male S2 gently swollen on apical part; male S6 expanded apically (Murao et al. 2014: figs 5-8, 15, 20) Acanthalictus Cockerell, 1924

- Male clypeus normal, not deflected; female labrum with basal elevation (as in Fig. 4D); male labrum without basal elevation or with low basal elevation; female mandible with a preapical tooth; male S2 flat; male S6 straight apically

2. Head and mesosoma with brilliant or dull green-metallic luster in both sexes (mesepisternum with shallow PP or reticulate PP in both sexes, see Murao et al. 2015b: figs 1e, 6e, 20e).

Dialictus Robertson, 1902

- Body generally black 3

3. Posterior surface of propodeum generally with complete lateral carina (Murao 2017a: fig. 3b); mesepisternum with coarse reticulate-rugulae over entire surface (Murao 2017a: fig. 2c)...

Sphecodogastra Ashmead, 1899

- Posterior surface of propodeum with incomplete lateral carina not reaching metapostnotum (Murao 2017a: fig. 3c); mesepisternum with shallow or reticulate PP (Fig. 2E; Murao 2017b: fig. 1d)

Hemihalictus Cockerell, 1897

Three species, L. (Sphecodogastra) boreale Svensson, Ebmer \& Sakagami, 1977, L. (S.) solisortus Ebmer \& Maeta, 1994, and L. (S.) subtropicum Sakagami, Miyanaga \& Maeta, 1994, from Japan are similar to L. (Hemihalictus) by having the posterior surface of the propodeum with an incomplete lateral carina (sometimes as variation) (Murao \& Tadauchi 2007). However, these species can be separated from L. (Hemihalictus) by the mesepisternum with coarse reticulate-rugulae.

\section{The sexstrigatus group}

\section{Diagnosis}

Species of the sexstrigatus group are characterized by a combination of the following characters: 1) male antenna short, not reaching metasoma (Fig. 2A); 2) male labrum with well-developed basal elevation (Fig. 2B) (except for Lasioglossum (Hemihalictus) ohei Hirashima \& Sakagami, 1966); 3) male labrum with distal process (Fig. 2B); 4) male head with genal process as variation (Fig. 2C-D); 5) female mesepisternum reticulate-punctate on lower area (Fig. 2E); 6) mesepisternum without tubercle in both sexes; 7) female metasomal terga with distinct fimbriae on posterior margin (Fig. 2F) (except for L. (H.) sphecodicolor Sakagami \& Tadauchi, 1995 ); 8) male S8 with well-developed (over S7) median process (Fig. 3A); 9) gonobase ventral arms of male genitalia connected with each other at upper ends (Fig. 3C); 10) gonocoxite of male genitalia smooth (Fig. 3B-D); 11) gonostylus of male genitalia small and simple, bud-like (Fig. 3B-C); and 12) the ventral retrorse lobe of male genitalia not reaching gonobase (Fig. 3B-C). 

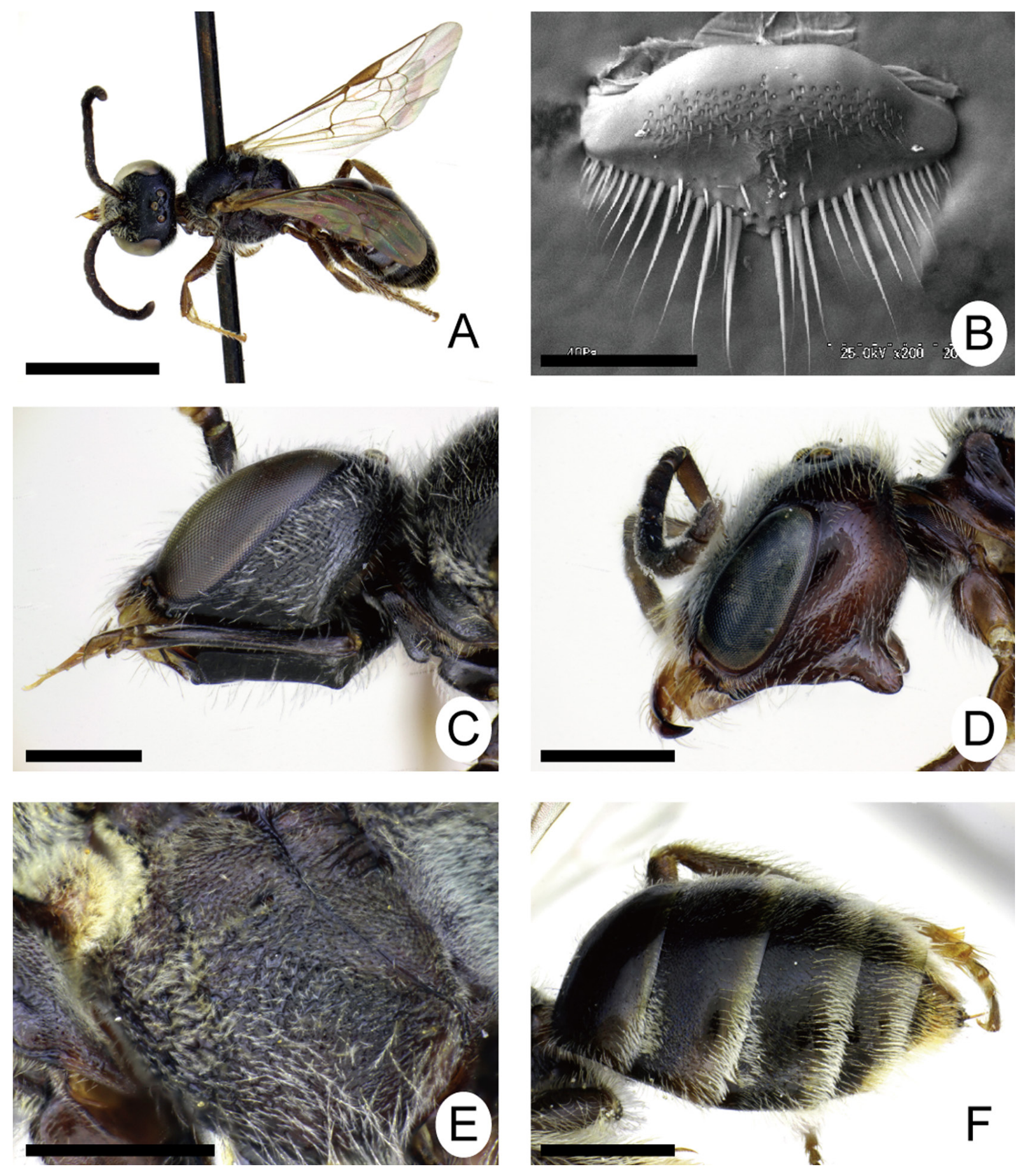

Fig. 2. A, E. Lasioglossum (Hemihalictus) sexstrigatus (Schenck, 1869). A. đ, lateral habitus. E. O, mesepisternum. - B. L. (H.) taeniolellum (Vachal, 1903), ô, labrum. - C, F. L. (H.) frigidum Sakagami \& Ebmer, 1996. C. Ô, cephalic polymorphism. F. o, metasomal terga. - D. L. (H.) simplicior (Cockerell, 1931), ${ }^{\lambda}$, cephalic polymorphism. Scale bars: A $=2 \mathrm{~mm} ; \mathrm{B}=0.2 \mathrm{~mm} ; \mathrm{C}, \mathrm{E}=0.5 \mathrm{~mm}$; D, $\mathrm{F}=1 \mathrm{~mm}$. 

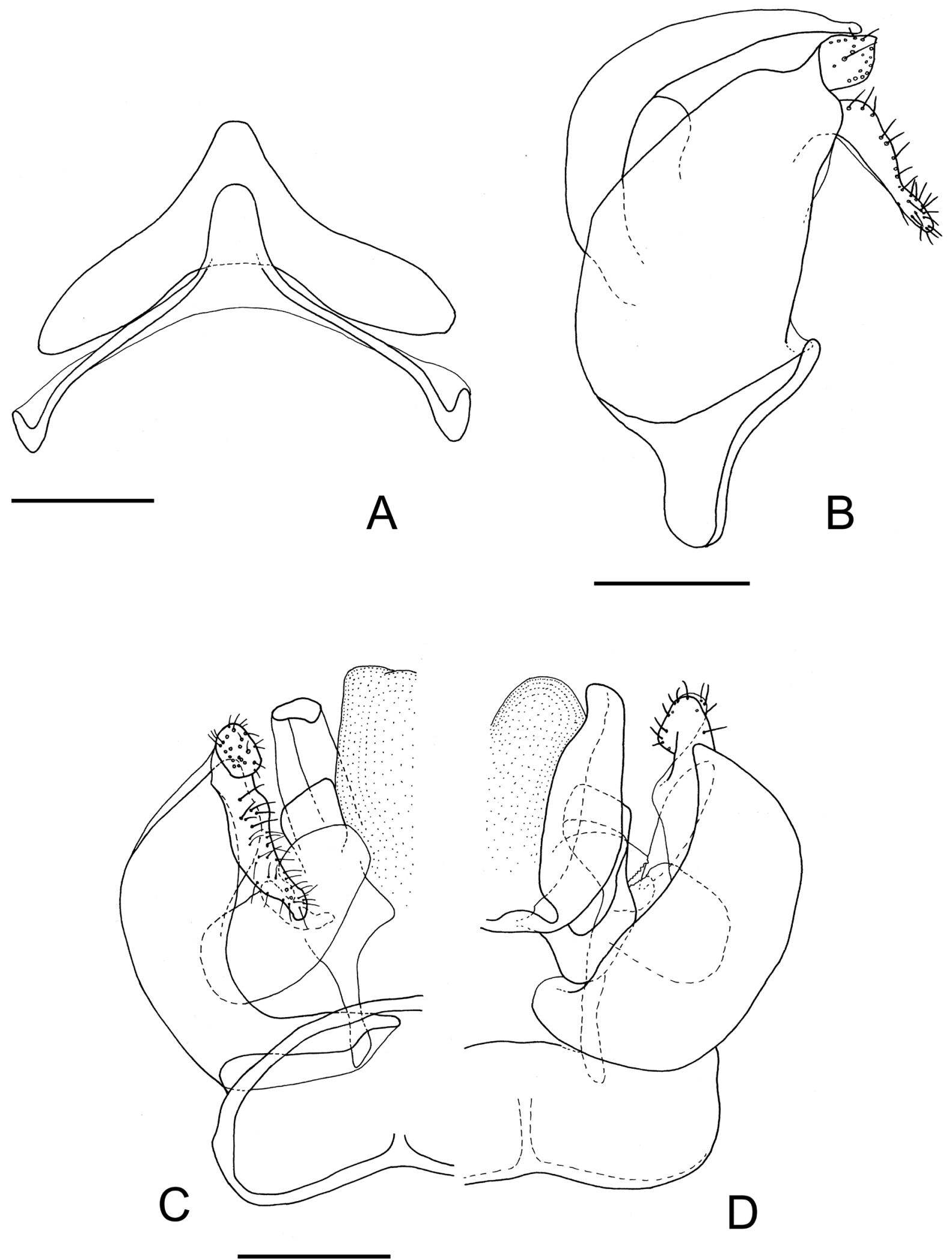

Fig. 3. Lasioglossum (Hemihalictus) sexstrigatus (Schenck, 1869), §̂. A. S7-S8. B. Genitalia in lateral view. C. Genitalia in ventral view. D. Genitalia in dorsal view. Scale bars: $0.1 \mathrm{~mm}$. 
The Japanese species of Hemihalictus are classified into five species groups (nitidiusculum, japonicum, semilucens, sexstrigatus, and villosulum groups). The sexstrigatus group is separated from the other four groups by the male head with genal process, the female metasomal terga generally with distinct fimbriae on posterior margin, and male S8 with developed median process.

Variation (male cephalic polymorphism)

The members of sexstrigatus group except for Lasioglossum (Hemihalictus) frigidum Sakagami \& Ebmer, 1996 display male cephalic polymorphism (Sakagami et al. 1966; Ebmer et al. 1994; Sakagami \& Ebmer 1996; Murao et al. 2010). This polymorphism is caused by the allometric development of the head (Sakagami et al. 1966). The presence of a genal process is characteristic of the sexstrigatus group, but is not known from the japonicum group (Sakagami et al. 1966; Ebmer et al. 1994; Sakagami \& Tadauchi 1995; Murao et al. 2010). Male cephalic polymorphism with allometric variation is known to occur in various bee families such as Andrenidae Latreille, 1802, Colletidae Lepeletier, 1841, and Halictidae Thomson, 1869 (summarised in Danforth et al. 2019). It also appears that such male cephalic polymorphism often occurs in communal species (Maeta 2000; Danforth et al. 2019). In the Japanese species of the sexstrigatus group, L. (H.) ohei has indeed been reported as a communal species (Sakagami et al. 1966). The other Japanese species with male cephalic polymorphism may also be communal.

\section{Distribution}

This group is distributed from the Palearctic to northern Oriental Region. It is diverse in eastern Asia.

\section{Comments}

Lasioglossum sexstrigatum was originally described as Halictus sexstrigatus by Schenck. From the scientific name '-strigatus', the original spelling was retained in accordance with Article 31.2.2 of the ICZN (International Commission on Zoological Nomenclature) Code.

\section{Species included in Japan}

1) L. amamiense Ebmer \& Sakagami, 1994

2) L. frigidum Sakagami \& Ebmer, 1996

3) L. ikudomei sp. nov.

4) L. kiautschouense (Strand, 1910)

5) L. ohei Hirashima \& Sakagami, 1966

6) L. simplicior (Cockerell, 1931)

7) L. smilodon Ebmer \& Sakagami, 1994

8) L. spectrum sp. nov.

9) L. speculinum (Cockerell, 1925)

10) L. sphecodicolor Sakagami \& Tadauchi, 1995

11) L. subsimplicior sp. nov.

12) L. tadauchii Murao, 2012

13) L. taeniolellum (Vachal, 1903)

The following 10 species were included as members of the sexstrigatus group sensu Sakagami \& Ebmer (1996), Pesenko (2007a), and Murao et al. (2010) in Japan (Ebmer et al. 1994; Pesenko 2007b; Murao et al. 2010): 1) Lasioglossum (Hemihalictus) bicornutum Murao, 2010, 2) L. (H.) canaliculatum Murao, 2010, 3) L. (H.) donanense Murao, 2010, 4) L. (H.) japonicum (Dalla Torre, 1896), 5) L. (H.) kankauchare (Strand, 1914), 6) L. (H.) latifacies Murao, 2010, 7) L. (H.) silivicolum Murao, 2010, 8) L. (H.) urumaense Murao, 2020, 9) L. (H.) yonaguniense Murao, 2010, and 10) L. (H.) zipangu Ebmer \& Sakagami, 1994. 
As stated above, these species, except for L. (H.) bicornutum, L. (H.) kankauchare, L. (H.) latifacies, and $L$. (H.) silvicolum, form a separate clade as the japonicum group (Fig. 1). Both L. (H.) latifacies and $L$. (H.) silvicolum are included in the japonicum group because males (undescribed) of both species share a non-homoplasious syapomorphy of this group (Murao unpublished). The Japanese specimens of L. (H.) kankauchare recorded by Blüthgen (1925, as Halictus kankaucharis) have been preserved in ZMHB. I visited ZMHB in 2012 to examine the bee specimens from the Oriental Region. At that time, I also examined the Japanese specimens of $L$. $(H$.) kankauchare. As a result, the Japanese specimens of L. (H.) kankauchare recorded by Blüthgen (1925) proved to be a misidentification of L. (H.) japonicum.

\section{Comments on non-Japanese species excluded from the sexstrigatus group}

Lasioglossum (Hemihalictus) micante (Michener, 1993) endemic in Taiwan belongs to the sexstrigatus group sensu Sakagami \& Ebmer (1996), Pesenko (2007a) and Murao et al. (2010) (Michener 1993). According to Michener (1993), a male (holotype) of $L$. (H.) micante (female unknown) lacks both the genal process of the head and the median process of S8. This species probably belongs to a different species group in the sexstrigatus group. However, since only a male of this species is known, future taxonomic studies of the genus Lasioglossum in Taiwan will be necessary.

Lasioglossum (Hemihalictus) amamiense Ebmer \& Sakagami, 1994 Fig. 18D

Lasioglossum (Evylaeus) amamiense Ebmer \& Sakagami in Ebmer et al., 1994: 32 (holotype: ELKU,, , type locality=Shinmura, Nishinakama, Amami Oshima Is., Kagoshima Pref., Japan, examined).

Lasioglossum (Evylaeus) amamiense - Murao et al. 2010: 3, 31-32 (in key), figs 1-2 (ㅇํ).

\section{Diagnosis}

Females are similar to Lasioglossum (Hemihalictus) taeniolellum (Vachal, 1903) but differ by the labrum without lateral projection on distal process (Murao et al. 2010: fig. $1 \mathrm{~m}$ ) and mesepisternum with shallow PP on upper area (Murao et al. 2010: fig. 1f). In contrast, in L. (H.) taeniolellum, the distal process of labrum has a horn-like lateral projection (Fig. 14D) and a mesepisternum with deep PP on the upper area.

\section{Distribution}

Japan (central Ryukyus: Amami-Ohshima Is., Kikai-jima Is., and Tokuno-shima Is.).

\section{Flight records}

Female: March to October.

Male: May to September (Murao et al. 2010).

\section{Flower records}

Thirteen species in 9 families were reported as floral records by Murao et al. (2010).

\section{Habitat}

This species has been collected from cultivated and urban areas at low elevations and seaside wasteland (Murao et al. 2010). 
Lasioglossum (Hemihalictus) frigidum Sakagami \& Ebmer, 1996

Figs 2C, F, 4, 15A, 17A, 19D, 20A

Lasioglossum (Evylaeus) frigidum Sakagami \& Ebmer, 1996: 899, figs 1-2, 3a-b, 4a-b, 5a, 6b (q đ̂) (holotype: Systematic Entomology, Faculty of Agriculture, Hokkaido University, Japan, + , type locality=Amagamori (in Misawa), Aomori Pref., Honshu, Japan).

\section{Diagnosis}

Females are similar to Lasioglossum (Hemihalictus) epicinctus (Strand, 1914) from Taiwan. According to Sakagami \& Ebmer (1996), the differences between L. (H.) frigidum and L. (H.) epicinctus are not clearly described. The type specimen of $L$. (H.) epicinctus at the Senckenberg Deutsches Entomologisches Institut (Müncheberg, Germany) was examined in 2012. Based on this examination, the female of L. (H.) frigidum is separated from $L$. (H.) epicinctus by the supraclypeal area dimly shiny (IS weakly tessellate), the ridges of metapostnotum long, nearly reaching the posterior margin as in Fig. 4F, and the lineolation of $\mathrm{T} 1$ present over the entire surface (Fig. 15A). In contrast, in L. (H.) epicinctus, the supraclypeal area weakly shiny (IS nearly smooth), the ridges of metapostnotum short (only present on basal area), and the lineolation of T1 present on basal and apical areas.

\section{Material examined}

\section{Paratypes}

JAPAN-Hokkaido 2 2 $ᄋ$; Abashiri-district, Hamakoshimizu; 19 Jun. 1967; H. Fukuda and K. Yamauchi leg.; MNHAH. - Honshu • 1 क; Aomori Pref., Misawa, Amagamori; 16 Aug. 1986; M. Yamada leg.; MNHAH • 1 q; Ibaraki Pref., Muramatsu; 13 May 1981; M. Takahashi leg.; MNHAH.

\section{Other material}

JAPAN - Honshu • 1 q; Tottori Pref., Yumiga-hama; 8 Aug. 1993; Y. Maeta leg.; MNHAH • 1 \%; same location as for preceding; 6 Sep. 1993; Y. Maeta leg.; MNHAH • 1 đ̊; Shimane Pref., Izumo-shi, Sotozono-cho; 12 Jul. 1994; Y. Maeta and K. Minagi leg.; SULE 1 o ; same location as for preceding; 10 Jun. 1995; Y. Maeta and K. Minagi leg.; SULE. - Kyushu • 2 우; Fukuoka Pref., Itoshima-shi, Shima-machi, Nigino-hama; 33³5'22.329" N, 1308'8.868" E; 17 Aug. 2013; R. Murao leg.; ELKU • $1 \mathrm{O}$; same location as for preceding; 12 Jul. 2014; R. Murao leg.; ELKU • 1 q; same location as for preceding; 6 Jun. 2015; R. Murao leg.; ELKU • 1 क; Fukuoka Pref., Fukuoka-shi, Nishi-ku, Imazunagahama; 33³6'37.64" N, 130¹5'34.919" E; 2 Jul. 2006; R. Murao leg.; ELKU • 1 ठे; same collection data as for preceding; ELKU • 1 क; same location as for preceding; 28 Jun. 2009; R. Murao leg.; ELKU $\bullet 1$; ; same collection data as for preceding; ELKU • 1 क ; same location as for preceding; 2 Aug. 2009; R. Murao leg.; ELKU • 1 ; same collection data as for preceding; ELKU • 1 क; same location as for preceding; 16 Aug. 2011; R. Murao leg.; ELKU • 3 9 ; same location as for preceding; 29 Jun. 2013; R. Murao leg.; ELKU $\bullet 6 \widehat{\partial}^{\lambda}$; same collection data as for preceding; ELKU $\bullet 1$ क ; same location as for

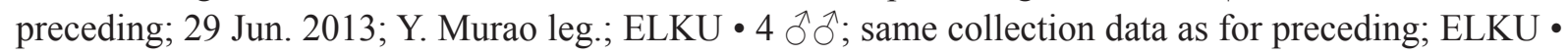
1 क; same location as for preceding; 17 Aug. 2013; R. Murao leg.; ELKU $\bullet 1$ §; same collection data as for preceding; ELKU • 1 \%; same location as for preceding; 17 May 2014; R. Murao leg.; ELKU • 2 우; Fukuoka Pref., Fukuoka-shi, Nishi-ku, Ikino-matsubara; 3334'51.671" N, 130¹8'1.335" E; 8 Jul. 2013; R. Murao leg.; ELKU • 1 क; Fukuoka Pref., Fukuoka-shi, Higashi-ku, Shikano-shima, Gebaga-hama; 3340'57.566" N, 130¹7'18.933" E; 20 Sep. 2012; R. Murao leg.; ELKU • 1 क; same location as for preceding; 15 Aug. 2013; R. Murao leg.; ELKU • 1 q; Fukuoka Pref., Kasuya-gun,

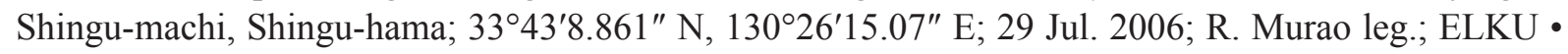

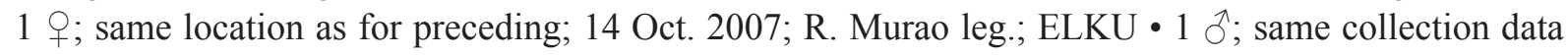
as for preceding; ELKU • 1 q; same location as for preceding; 10 May 2009; R. Murao leg.; ELKU • 
39 우 ; same location as for preceding; 3 Jun. 2011; R. Murao leg.; ELKU • 1 \%; same location as for preceding; 16 Jul. 2011; R. Murao leg.; ELKU • 1 क; same location as for preceding; 20 Sep. 2012; R. Murao leg.; ELKU • 1 \%; same location as for preceding; 4 May 2014; R. Murao leg.; ELKU • 3 q $ᄋ$;

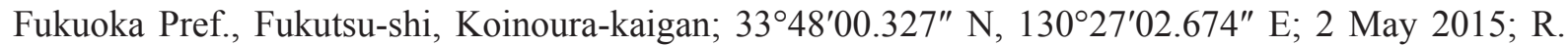
Murao leg.; ELKU • 5 우; Kumamoto Pref., Amakusa, Tomioka-shiki; 19 Jun. 1931; Esaki and Hori
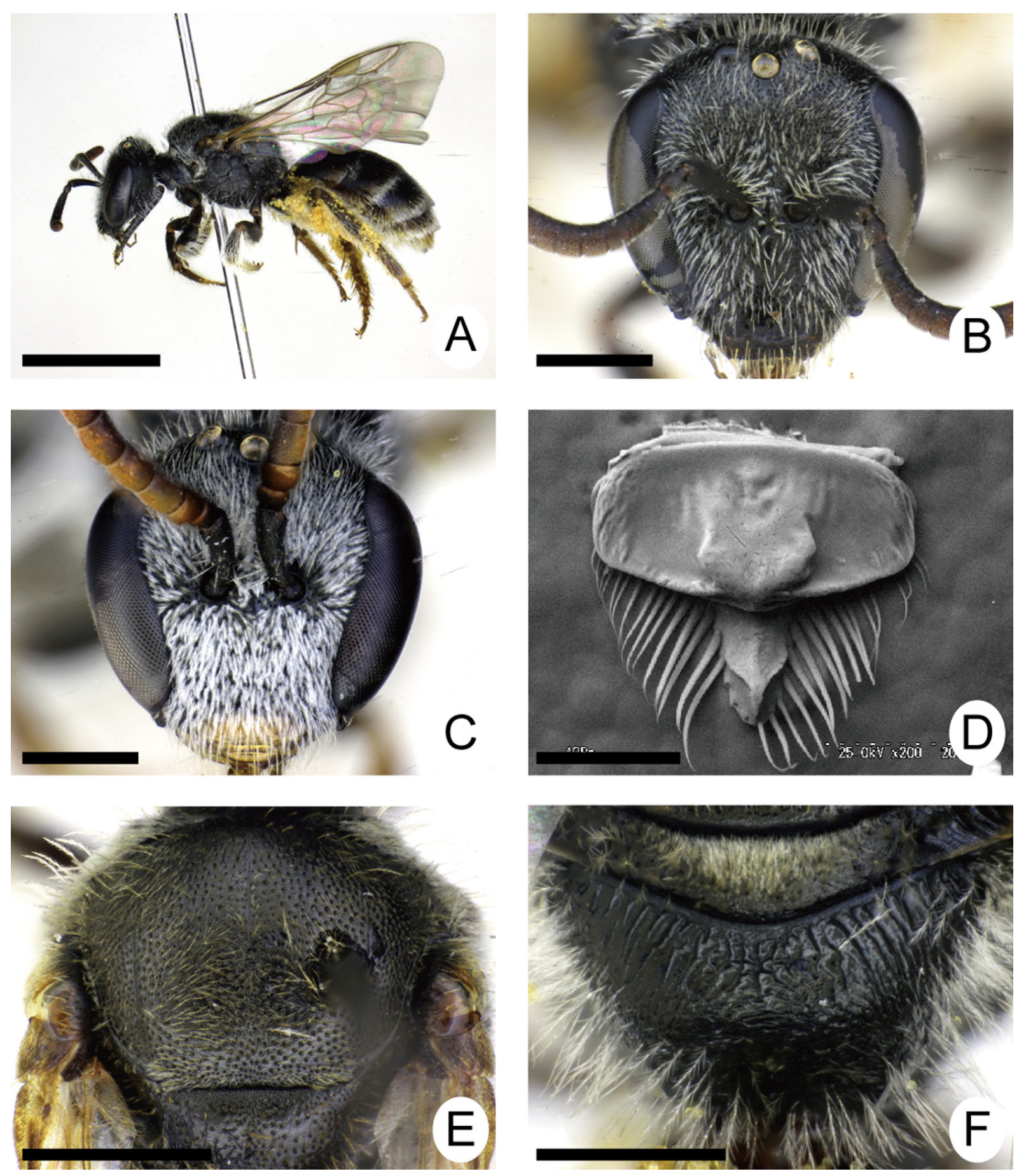

Fig. 4. Lasioglossum (Hemihalictus) frigidum Sakagami \& Ebmer, 1996. A. + , lateral habitus. B. + , head in frontal view. C. $O^{\top}$, head in frontal view. D. + , labrum. E. $q$, mesoscutum. F. $q$, metapostnotum. Scale bars: $\mathrm{A}=2 \mathrm{~mm} ; \mathrm{B}, \mathrm{E}-\mathrm{F}=0.5 \mathrm{~mm} ; \mathrm{C}-\mathrm{D}=0.2 \mathrm{~mm}$. 
leg.; ELKU. - Ryukyus • 1 q; Kagoshima Pref., Ôsumi-shotô, Tanega-shima, Hamada; 2 Aug. 1984; Sk. Yamane leg.; KWC • 1 क; Tanega-shima Is., Nakatane, Yakutsu; 14 Aug. 1991; M. Goubara leg.; SULE.

\section{Distribution}

Japan (Hokkaido, Honshu, Izu-shotô Islands, Shikoku, Kyushu, northern Ryukyus).

\section{Flight records}

Female: April to October.

Male: June to October. The flight records of male are based on the phenological data reported by Minagi et al (2000).

\section{Flower records}

Five species in 4 families were reported as floral records in Japan by Sakagami \& Ebmer (1996), 8 species in 5 families by Minagi et al. (2000), and 5 species in 4 families by Gôkon (2006). The total number of species including my data is 14 in 6 families as follows. Apiaceae: Coelopleurum gmelinii (DC.) Ledeb.; Glehnia littoralis F.Schmidt ex Miq. Asteraceae: Hieracium umbellatum L.; Ixeris repens (L.) A.Gray; Melanthera prostrata (Hemsl.) W.L.Wagner \& H.Rob.; Sonchus brachyotus DC.; Taraxacum officinale Weber ex F.H.Wigg. Brassicaceae: Arabis stelleri DC. var. japonica (A.Gray) F.Schmidt; Brassica sp. Convolvulaceae: Calystegia soldanella (L.) R.Br.; Cuscuta campestris Yunck. Lamiaceae: Vitex rotundifolia L.f. Rosaceae: Potentilla chinensis Ser.; Rosa rugosa Thunb.

\section{Habitat}

Lasioglossum frigidum has been collected only in coastal sand dunes. One of the collecting sites is shown in Fig. 19D.

Lasioglossum (Hemihalictus) ikudomei sp. nov.

urn:1sid:zoobank.org:act:2F66A01B-2176-4764-8DB7-59D53A335FB5

Figs $5,15 \mathrm{~B}, 18 \mathrm{D}, 20 \mathrm{~B}$

\section{Diagnosis}

Females are similar to Lasioglossum (Hemihalictus) smilodon Ebmer \& Sakagami, 1994 from Japan but are separated from them by the supraclypeal area shinier (IS weakly tessellate), the PP on the mesoscutum sparser (IS $=3 \mathrm{~d}$ in maximum) (Fig. 5E), and T1 with very weak lineolation. In contrast, in L. (H.) smilodon, the supraclypeal area is dimly shiny (IS distinctly tessellate), the PP on the mesoscutum denser (IS $=2 \mathrm{~d}$ at maximum) (Fig. 9E), and the lineolation of T1 clearer.

\section{Etymology}

The specific name is dedicated to Dr Shuichi Ikudome (KWC), who contributed greatly to clarify the bee fauna of Ryukyus Islands, southwestern Japan.

\section{Material examined}

\section{Holotype}

JAPAN - Ryukyus • + ; Okinawa Pref., Miyako-jima, Henna-zaki; 3 Jul. 1992; S. Ikudome leg.; ELKU. [Verbatim label: MIYAKO-JIMA/Henna-zaki/OkinawaPref./3. VII. 1992/S. Ikudomeleg.//HOLOTYPE // Lasiioglossum (Hemihalictus) ikudomei Murao] 


\section{Paratypes}

JAPAN - Ryukyus • 1 ; Yoron Is., Maeno-hama; 4 Jun. 1989; KWC・ 1 + ; Okinawa Pref., Kunigami, Hedo; 5 Apr. 1979; K. Kusigemati leg.; ELKU • 2 q ; ; Okinawa Pref., Hedo; 5 Apr. 1979; K. Ohara leg.; ELKU • 2 q $O$; Okinawa Pref., Kunigami-gun, Kunigami-son, Cape Hedo; 26 $6^{\circ} 2^{\prime}$ N, $128^{\circ} 15^{\prime}$ E; 2 Apr. 2017; K. Otsui leg.; cMur • 1 q; Okinawa Pref., Okinawa-jima, Kunigami-gun, Kunigami-son, Ada;
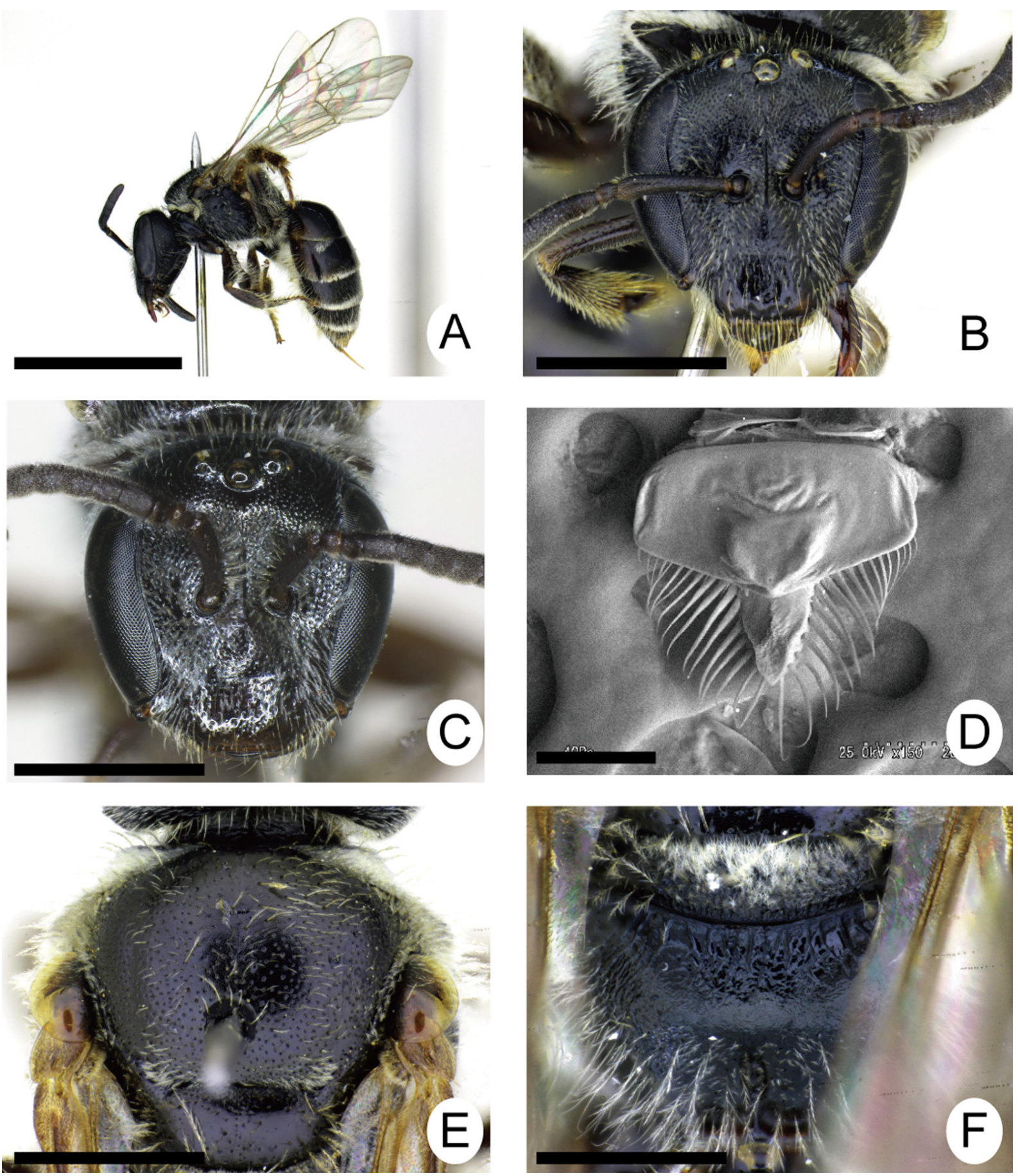

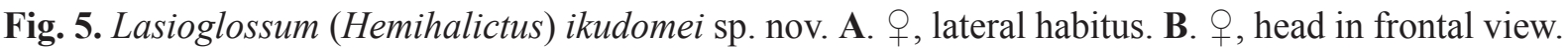
C. $\hat{\gamma}$, head in frontal view. D. + , labrum. E. + , mesoscutum. F. + , metapostnotum. Scale bars: A = $2 \mathrm{~mm} ; \mathrm{B}-\mathrm{C}, \mathrm{E}=1 \mathrm{~mm} ; \mathrm{D}=0.2 \mathrm{~mm} ; \mathrm{F}=0.5 \mathrm{~mm}$. 
22 Aug. 2007; Y. Nishimura leg.; cMur • 1 q; Miyako Is., Nishi-heana; 27 Mar. 1995; T. Matsumura leg.; ELKU • 1 ठ̊; Okinawa Pref., Miyako-jima, Henna-zaki; 3 Jul. 1992; S. Ikudome leg.; ELKU • 1 o ; Okinawa Pref., Iriomote Is.; 16-17 Mar. 2005; Y. Maeta leg.; SULE.

\section{Description}

Female

Measurements ( $\mathrm{n}=5$, unit $\mathrm{mm}) . \mathrm{BL}=5.13-5.63(5.43 \pm 0.23), \mathrm{WL}=4.25-4.88(4.65 \pm 0.26), \mathrm{HL}=1.55-$ $1.65(1.61 \pm 0.04), \mathrm{HW}=1.48-1.65 \quad(1.57 \pm 0.06), \quad \mathrm{IOD}=0.26-0.29 \quad(0.28 \pm 0.02), \quad \mathrm{OOD}=0.24-0.31$ $(0.26 \pm 0.02), \quad \mathrm{OCD}=0.18-0.19 \quad(0.19 \pm 0.01, \mathrm{n}=4), \quad \mathrm{UOD}=0.94-1.03 \quad(0.98 \pm 0.04), \quad \mathrm{MOD}=1.10$ $1.23(1.15 \pm 0.05), \mathrm{LOD}=0.84-0.94(0.88 \pm 0.04), \mathrm{IAD}=0.15-0.16(0.16 \pm 0.01), \mathrm{AOD}=0.26-0.31$ $(0.28 \pm 0.02), \mathrm{CAL}=0.29-0.32(0.31 \pm 0.01), \mathrm{CPL}=0.34-0.37(0.35 \pm 0.01), \mathrm{EL}=1.75-1.85(1.80 \pm 0.04)$, $\mathrm{EW}=0.39-0.45(0.41 \pm 0.04), \mathrm{GW}=0.29-0.39(0.35 \pm 0.04), \mathrm{SPL}=0.61-0.66(0.64 \pm 0.02), \mathrm{F} 1 \mathrm{~L}=0.10$ $(0.10 \pm 0.00), \quad \mathrm{F} 2 \mathrm{~L}=0.08 \quad(0.08 \pm 0.00), \quad \mathrm{F} 3 \mathrm{~L}=0.08 \quad(0.08 \pm 0.00), \quad \mathrm{F} 2 \mathrm{~W}=0.13-0.15 \quad(0.14 \pm 0.01)$, $\mathrm{MsW}=1.80-2.05 \quad(1.93 \pm 0.09), \quad \mathrm{SCL}=0.38-0.45 \quad(0.43 \pm 0.03), \quad \mathrm{MNL}=0.25-0.30 \quad(0.27 \pm 0.02)$, $\mathrm{MPL}=0.25-0.33(0.28 \pm 0.03), \mathrm{MtW}=1.75-2.10(1.97 \pm 0.13)$.

Coloration. Body black except for the following parts: mandible reddish brown apically; flagellum brown or blackish brown ventrally; tegula yellowish brown translucent; tibial spur yellow; metasomal terga narrowly yellowish brown translucent apically. Wings transparent, veins and stigma brown.

PubESCEnCE. Body hairs whitish, and covered with erect and sparse straight or fine branched hairs except for the following parts: pronotum moderately densely tomentose dorsally and around lobe; hind trochanter, femur, and tibia mixed with plumose hairs, forming scopa. Disc of T1 without distinct short hairs on medial area.

Structure AND SCUlPtURE HEAD. Slightly longer than wide or nearly as long as wide; HW:HL=1:1.03. Vertex rounded in frontal view. MOD:UOD:LOD=1:0.85:0.76. IOD:OOD:OCD=1:0.95:0.69. IAD:AOD $=1: 1.86$. Ocellocular area with moderately dense PP, IS smooth (IS $=0.5-3 \mathrm{~d}$ ). Paraocular area and frons weakly shiny, with shallow reticulate PP. Supraclypeal area slightly convex, weakly shiny, with sparse PP, IS weakly tessellate (IS $=1-4 \mathrm{~d}$ ). CPL:CAL $=1: 0.87$. Clypeus nearly flat, with sparse PP over entire surface, IS very weakly tessellate on upper half or $1 / 3$ and smooth on lower half or $2 / 3(\mathrm{IS}=1-5 \mathrm{~d})$. EW:GW=1:0.86. Genal area to postgena with distinct straight ridges. Malar space linear. Occiput not carinate. Hypostomal carinae nearly parallel. Mandible bidentate. Labrum (Fig. 5D): basal area approximately $1.9 \times$ as wide as long; distal process approximately $0.6 \times$ as long as basal area, tongue-like, and without lateral projection; distal keel rounded, pointed apically. Antenna short, not reaching metasoma. F2L:F2W=1:1.72; flagellum nearly flattened ventrally.

Thorax. Dorsolateral angle of pronotum obtuse; lateral surface without ridges; lateral lobe rounded. Tegula ovoid, nearly smooth. Mesoscutum (Fig. 5E) with moderately dense PP over entire surface; IS weakly tessellate over entire surface (particularly very weak on posterior area) $($ IS $=0.5-3 \mathrm{~d}$ ); parapsidal line a narrow groove. Mesoscutellum with 2-4 PP on submedian area and denser PP on marginal area; IS nearly smooth on submedian area and very weakly tessellate on marginal area (IS $=2-5 \mathrm{~d}$ on submedian area, $=0.5-2 \mathrm{~d}$ on marginal area). Metanotum weakly rugulose. Mesepisternum weakly shiny, with dense shallow PP on upper area and reticulate PP on lower area; IS nearly smooth on upper area (IS $=0.5-1 \mathrm{~d}$ on upper area). SCL:MNL:MPL=1:0.62:0.66. Propodeum: metapostnotum (Fig. 5F) gently inclined, with irregular sinuate ridges on anterior half in holotype and two paratypes (remaining five paratypes with short longitudinal ridges), with weak tessellation on posterior half, and nearly smooth among ridges; junction between metapostnotum and posterior surface not carinate, with weak tessellation; lateral surface weakly rugulose; posterior surface with lateral carina on lower half, without oblique carina. Coxae usual shape, without tubercle. Fore trochanter narrow, longer than wide. Basitibial 
plate of hind leg carinate marginally. Inner hind tibial spur with slender 2-4 teeth as in Fig. 20B $(n=7)$. Fore wing with three submarginal cells.

Abdomen. Disc of T1 without distinct PP on medial area, and with very weak lineolation interrupted on medial area (Fig. 15B). Disc of T2 nearly smooth on anterior to medial area in holotype and two paratypes, and with weak lineolation on posterior area (anterior and posterior area with weak lineolation in four paratypes). Discs of T3-T4 with weak lineolation over entire surface.

\section{Male}

Measurements ( $\mathrm{n}=1$, unit $\mathrm{mm}$ ). $\mathrm{BL}=4.23, \mathrm{WL}=3.92, \mathrm{HL}=1.56, \mathrm{HW}=1.51, \mathrm{IOD}=0.29, \mathrm{OOD}=0.29$, $\mathrm{OCD}=0.16, \mathrm{UOD}=0.98, \mathrm{MOD}=1.04, \mathrm{LOD}=0.84, \mathrm{IAD}=0.20, \mathrm{AOD}=0.24, \mathrm{CAL}=0.31, \mathrm{CPL}=0.33$, $\mathrm{EL}=1.07, \quad \mathrm{EW}=0.40, \quad \mathrm{GW}=0.44, \quad \mathrm{SPL}=0.44, \quad \mathrm{~F} 1 \mathrm{~L}=0.11, \quad \mathrm{~F} 2 \mathrm{~L}=0.18, \quad \mathrm{~F} 3 \mathrm{~L}=0.16, \quad \mathrm{~F} 2 \mathrm{~W}=0.13$, $\mathrm{MsW}=1.55, \mathrm{SCL}=0.36, \mathrm{MNL}=0.22, \mathrm{MPL}=0.27, \mathrm{MtW}=1.35$.

COLORATION. Body black except for the following parts: mandible yellowish brown except for apically reddish brown; labrum dark yellow; pronotal lobe yellowish brown; tegula yellowish brown translucent; legs brown, without distinct yellow marks; tibial spur yellow; metasomal terga broadly yellowish brown translucent apically. Wings transparent, veins and stigma pale brown.

PuBESCENCE. Body hairs whitish, and covered with erect and sparse straight or fine branched hairs except for the following parts: lower paraocular area and pronotal dorsum to lobe sparsely tomentose. Disc of T1 with sparse hairs only on marginal area. Disc of T2-T4 with sparse short hairs over entire surface. T2-T3 with thin apical fimbriae, less distinct than in the female.

Structure And sculpture HeAd. Nearly as long as wide; HW:HL $=1: 1.03$. Vertex rounded in frontal view. MOD:UOD:LOD=1:0.94:0.81. IOD:OOD:OCD $=1: 1: 0.54$. IAD:AOD $=1: 1.22$. Ocellocular area with moderately dense PP, IS smooth (IS $=1-4$ d). Paraocular area and frons weakly shiny, with shallow reticulate PP. Supraclypeal area slightly convex, weakly shiny, with moderately dense PP, IS weakly tessellate (IS=1-3 d). CPL:CAL=1:0.93. Clypeus nearly flat, with sparse shallow PP over entire sutface; IS smooth (IS=1-6 d). EW:GW=1:1.11. Genal area on lower margin and postgena with straight ridges. Malar space linear. Hypostomal carinae nearly parallel. Mandible edentate. Labrum with basal elevation, but not examined in detail. Antenna short, not reaching metasoma. F2L:F2W=1:0.75; flagellum nearly flattened ventrally.

Thorax. Dorsolateral angle of pronotum obtuse; lateral surface without ridges; lateral lobe rounded. Tegula ovoid, nearly smooth. Mesoscutum with moderately dense PP over entire surface; IS weakly tessellate on anterior margin, nearly smooth on rest parts (IS $=1.5-3 \mathrm{~d}$ ); parapsidal line a narrow groove. Mesoscutellum with sparse PP over entire surface; IS smooth (IS=2.5-6 d). Metanotum weakly rugulose. Mesepisternum with moderately dense PP over entire surface; IS smooth (IS $=1-3 \mathrm{~d}$ ). SCL:MNL:MPL=1:0.63:0.75. Propodeum: metapostnotum weakly shiny and gently inclined, with short straight ridges occupying anterior $2 / 3$; junction between metapostnotum and posterior surface not carinate, nearly smooth; lateral surface weakly reticulate; posterior surface nearly smooth, with lateral carina on lower $1 / 3$, and without oblique carina. Coxae usual shape, without tubercle. Fore trochanter narrow, longer than wide. Basitibial plate of hind leg carinate marginally. Inner hind tibial spur serrate. Fore wing with three submarginal cells.

ABdomen. Disc of T1 nearly smooth. Disc of T2-T3 with sparse fine PP; T2 weakly lineolate on apical margin; T3 weakly lioneolate on apical half. Disc of T4 weakly lineolate over entire surface. S7 with moderately long, apically rounded median process. 
GenitaLIA. Gonobase flat at bottom; gonocoxite smooth; ventral retrorse lobe tongue-like, moderately long but not reaching gonobase, with sparse short hairs ventrally.

\section{Distribution}

Japan (central to southern Ryukyus: Yoron-jima Is., Okinawa-jima Is., Miyako-jima Is., Iriomote-jima Is.).

\section{Flight period}

Female: middle March to late August.

Male: July.

\section{Flower records}

Ixeris japonica (Burm.f.) Nakai (Asteraceae).

\section{Lasioglossum (Hemihalictus) kiautschouense (Strand, 1910)}

Figs $6,15 \mathrm{C}, 17 \mathrm{~B}, 19 \mathrm{~A}, 20 \mathrm{C}$

Halictus kiautschouense Strand, 1910: 195 (holotype: ZMHB,, , type locality=Kiautshou, Tsingtou, China, examined).

Halictus kiautschauensis Blüthgen, 1922: 54 (unjustified emendation of Halictus kiautschouense Strand, 1910, comment by Pesenko 2007b: 111).

Halictus perplexans Cockerell, 1925: 10 (syntype: + , ZMHB, type locality=Preobragenya Bay, Russia, examined; $4+q$, USNM, type locality = Preobragenya Bay and Low Lighthouse, Russia). Syn. nov.

Lasioglossum (Evylaeus) kiautschouense - Ebmer 1978a: 212; 1996: 292; 2006: 572.

Lasioglossum (Evylaeus) perplexans - Ebmer 1996: 293; 2006: 571.

Evylaeus (Prosopalictus) kiautschouensis - Pesenko 2007b: 111.

Evylaeus (Prosopalictus) perplexans - Pesenko 2007b: 111.

Lasioglossum (Hemihalictus) kiautschouense - Murao 2017a: 460-461.

\section{Diagnosis}

Females are separated from the other members of the sexstrigatus group occurring in Japan by a combination of the following character states: IS of mesoscutum nearly smooth on posterior area; metasoma entirely black; metasomal terga with white fimbriae on lateral-apical margin; and disc of T1 with distinct sparse fine PP (Fig. 15C) and without lineolation (Murao 2017a).

\section{Material examined}

\section{Holotype}

CHINA・ • +; Tsingtou, Kiautshou; Jun.-Jul. 1903; S. Glaue leg.; ZMHB.

\section{Other material}

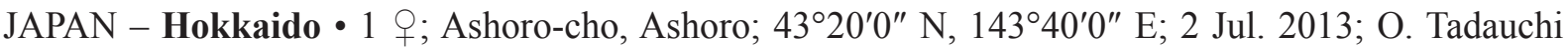
leg.; ELKU • 1 क; Asahikawa, Asahiyama; 24 Sep. 1970; MNHAH • 2 q 9 ; Ebetsubuto; 8-9 Jun. 1974; M. Ishikawa leg.; MNHAH • 3 q $q$; Asahikawa, Inosawa; 27 Jun. 1969; MNHAH • 10 q ; Kiritapp; 1972; MNHAH • 1 q; Moiwa; 3 Jun. 1972; Kawano leg.; MNHAH • 6 o 9 ; Kushiro, Tenneru n.; 1968; E. Ohtsuka leg.; MNHAH • 5 o q ; Tobetsu; 22 May-9 Jul. 1974; M. Ishikawa leg.; MNHAH • 6 우; Lake Shikotsu (Iburi), Morappu; 11-13 Aug. 1953; Y. Hirashima leg.; ELKU • 2 우; Mombetsu-gun, Engaru; 11 Aug. 1955; K. Morimoto leg.; ELKU. - Honshu • 2 우; Aomori Pref., Mt Iwaki; 23 Jun. 
1981; M. Yamada leg.; MNHAH • 1 क; Iwate Pref., Morioka, Kuriyagawa; 16 May 1964; Y. Maeta leg.; ELKU • 1 क; Yamagata Pref., Murayama, Tochiuda; 26 May 1975; O. Tadauchi leg.; ELKU • 1 क; Yamaguchi Pref., Hagi, Sengokudai; 23 May 1960; Y. Hirashima leg.; ELKU. - Izu Islands • 28 우; Hachijo Is., Okago-Sokoto; 5 Jun. 1964; Y. Hirashima and M. Shiga leg.; ELKU • 3 + $O$; Hachijo Is., Mitsune-Kantoyama; 30 May 1964; Y. Hirashima and M. Shiga leg.; ELKU • 2 q 9 ; Okago-Fuji; 26 May 1964; Y. Hirashima and M. Shiga leg.; ELKU • 5 q 9 ; Hachijo Is., Sokoto; 4 Jun. 1964; Y. Hirashima and M. Shiga leg.; ELKU • 2 q $ᄋ$; Hachijo Is., Nakanogo-Daigo yama-Mitsune; 1 Jun. 1964; Y. Hirashima and M. Shiga leg.; ELKU. - Kyushu • 1 q; Hiraodai (Buzen); 6 Jul. 1952; K. Yasumatsu leg.; ELKU • 2 웅 Mt Oita Pref., Kokonoe-machi, Sensui-san; 23 May 2005; K. Mitai leg.; cMur • 1 웅 Oita Pref.,

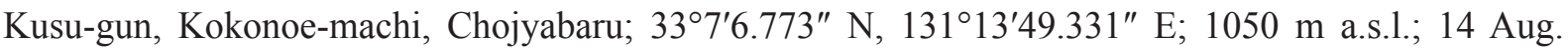
2010; R. Murao leg.; cMur • 1 क; same location as for preceding; 5 Sep. 2010; R. Murao leg.; cMur •

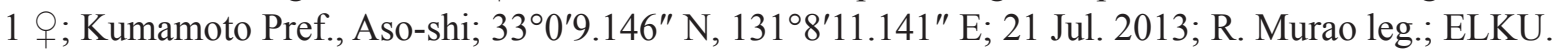

\section{Redescription}

MeAsurements $(\mathrm{n}=5$, unit $\mathrm{mm}) . \mathrm{BL}=4.50-4.88(4.68 \pm 0.17), \mathrm{WL}=4.00-4.63(4.38 \pm 0.27), \mathrm{HL}=1.42-$ $1.55(1.47 \pm 0.06), \mathrm{HW}=1.45-1.58 \quad(1.51 \pm 0.07), \mathrm{IOD}=0.26-0.29 \quad(0.27 \pm 0.02), \mathrm{OOD}=0.29-0.31$ $(0.29 \pm 0.01), \quad \mathrm{OCD}=0.18-0.19 \quad(0.18 \pm 0.01), \quad \mathrm{UOD}=0.97-1.03 \quad(0.99 \pm 0.03), \quad \mathrm{MOD}=1.10-1.16$ $(1.12 \pm 0.04), \quad \mathrm{LOD}=0.77-0.87 \quad(0.82 \pm 0.05), \quad \mathrm{IAD}=0.15-0.16 \quad(0.15 \pm 0.01), \quad \mathrm{AOD}=0.29-0.31$ $(0.30 \pm 0.01), \mathrm{CAL}=0.24-0.29(0.27 \pm 0.02), \mathrm{CPL}=0.29-0.32(0.31 \pm 0.01), \mathrm{EL}=1.60-1.75(1.67 \pm 0.07)$, $\mathrm{EW}=0.35-0.42(0.39 \pm 0.03), \mathrm{GW}=0.29-0.32(0.30 \pm 0.01), \mathrm{SPL}=0.58-0.68(0.62 \pm 0.04), \mathrm{F} 1 \mathrm{~L}=0.08-$ $0.10(0.09 \pm 0.01), F 2 \mathrm{~L}=0.08(0.08 \pm 0.00), \mathrm{F} 3 \mathrm{~L}=0.08(0.08 \pm 0.00), \mathrm{F} 2 \mathrm{~W}=0.11-0.15(0.14 \pm 0.01)$, $\mathrm{MsW}=1.60-1.80 \quad(1.69 \pm 0.10), \quad \mathrm{SCL}=0.33-0.40 \quad(0.36 \pm 0.03), \quad \mathrm{MNL}=0.20-0.23 \quad(0.21 \pm 0.01)$, $\mathrm{MPL}=0.23-0.25(0.25 \pm 0.01), \mathrm{MtW}=1.60-1.90(1.78 \pm 0.13)$.

\section{Female}

Coloration. Body black except for the following parts: mandible reddish brown apically; F4-F10 or F5-F10 yellowish brown ventrally; tegula yellowish brown translucent; tibial spur yellow; metasomal terga narrowly yellowish brown translucent apically. Wings transparent, veins and stigma yellowish brown.

PuBESCENCE. Body hairs whitish, and covered with erect and sparse straight or fine branched hairs except for the following parts: pronotum moderately densely tomentose on dorsal area and around lobe; hind trochanter, femur, and tibia mixed with plumose hairs, forming scopa.

Structure And SCUlPtURe HEAD. Nearly as long as wide; HW:HL $=1: 0.97$. Vertex rounded in frontal view. MOD:UOD:LOD=1:0.88:0.73. IOD:OOD:OCD $=1: 1.07: 0.67 . \mathrm{IAD}: \mathrm{AOD}=1: 1.96$. Ocellocular area densely puctate, IS smooth (IS $=0.5-1.5 \mathrm{~d}$ ). Paraocular area and frons weakly shiny, with shallow reticulate PP. Supraclypeal area nearly flat, weakly shiny, with moderately dense PP, IS weakly tessellate $(\mathrm{IS}=0.5-1 \mathrm{~d}) . \mathrm{CPL}: \mathrm{CAL}=1: 0.87$. Clypeus nearly flat, with dense PP on upper half and larger shallow PP on lower half, IS nearly smooth (IS $=0.5 \mathrm{~d}$ on upper half). $\mathrm{EW}: \mathrm{GW}=1: 0.77$. Genal area with weak straight ridges. Malar space linear. Occiput not carinate. Postgena distinctly tessellate. Hypostomal carinae nearly parallel. Mandible bidentate. Labrum (Fig. 6C): basal area approximately $2 \times$ as wide as long; distal process approximately $0.7 \times$ as long as basal area, narrow, and without lateral projection; distal keel pointed apically. Antenna short, not reaching metasoma. F2L:F2W=1:1.68; flagellum nearly flattened ventrally.

ThOARx. Dorsolateral angle of pronotum obtuse; lateral surface without ridges; lateral lobe rounded. Tegula ovoid, nearly smooth. Mesoscutum (Fig. 6D) with dense PP over entire surface; IS nearly smooth on posterior area, and distinctly tessellate on the rest area (IS $=0.5-2 \mathrm{~d}$ ); parapsidal line a narrow groove. Mesoscutellum with dense PP over entire surface, IS smooth (IS $=0.5-2 \mathrm{~d}$ ). Metanotum weakly rugulose. 
Mesepisternum weakly shiny, with reticulate PP over entire surface. SCL:MNL:MPL=1:0.57:0.68. Propodeum: metapostnotum (Fig. 6E) gently inclined, with straight ridges nearly attaining to posterior margin, and nearly smooth among ridges; the junction between metapostnotum and posterior surface not carinate; lateral surface weakly rugulose; posterior surface with lateral carina on lower half, without oblique carina. Coxae normal shape, without tubercle. Fore trochanter narrow, longer than wide. Basitibial
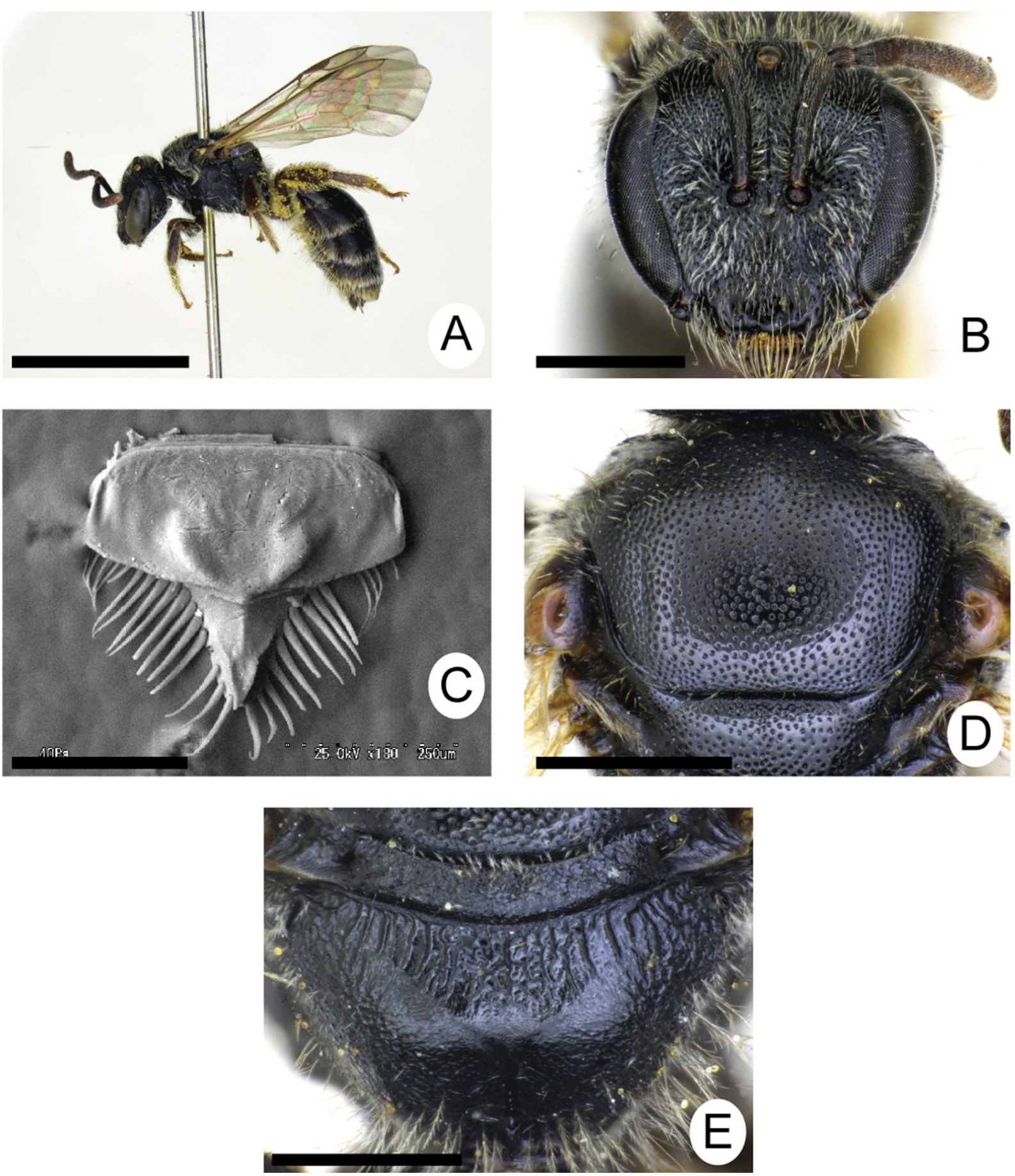

Fig. 6. Lasioglossum (Hemihalictus) kiautschouense (Strand, 1910), ㅇ. A. Lateral habitus. B. Head in frontal view. C. Labrum. D. Mesoscutum. E. Metapostnotum. Scale bars: A = $3 \mathrm{~mm}$; B, D-E $=0.5 \mathrm{~mm}$; $\mathrm{C}=0.25 \mathrm{~mm}$. 
plate of hind leg carinate marginally. Inner hind tibial spur with slender $2-4$ teeth as in Fig. $20 \mathrm{C}(\mathrm{n}=17)$. Fore wing with three submarginal cells.

Abdomen. Disc of T1 with sparse distinct fine PP on medial area and without lineolation over entire surface (Fig. 15C). Discs of T2-T4 without lineolation over entire surface (sometimes T4 with very weak lineolation).

\section{Male}

Not examined in the present study.

\section{Distribution}

Japan (Hokkaido, Honshu, Kyushu, Izu-shotô Islands), Korean Peninsula, Russian Far East, China.

\section{Flight records}

Female: May to September.

Males have been collected from July to August in Primorsky, Russian Far East (Ebmer 1996, 2006).

\section{Flower records}

The specimens examined in this paper were collected on the flowers of 7 species in 3 families as follows. Asteraceae: Leontodon taraxacoides (Vill.) Mérat; Sonchus brachyotus DC. Brassicaceae: Armoracia rusticana Gaertn., B.Mey. \& Scherb.; Barbarea orthoceras Ledeb.; Brassica rapa L. var. oleifera DC.; Rorippa sp. Fabaceae: Trifolium repens L.

\section{Habitat}

This species has been collected from semi-natural grassland in western Japan. One of the collecting sites is shown in Fig. 19A.

\section{Remarks}

According to Cockerell (1925), the syntypes of Halictus perplexans are preserved in USNM. During my visit to ZMHB in 2012, I found and examined a syntype of $H$. perplexans.

Lasioglossum (Hemihalictus) ohei Hirashima \& Sakagami, 1966 Figs 7, 15D, 17C, 19A, 20D

Lasioglossum (Evylaeus) ohei Hirashima \& Sakagami in Sakagami et al., 1966: 679 (holotype: ELKU, , , type locality=Misano, Kitami City, Kitami Province, Hokkaido).

\section{Diagnosis}

Females are similar to $L$. (H.) simplicior but separated from them by the head slightly longer than wide or nearly as long as wide (HL/HW ratio $1.01 \pm 0.02$ ), IS of mesoscutum nearly smooth on posterior margin, and metasomal terga with silky dull luster. In contrast, in L. (H.) simplicior, the head wider than long (HL/HW ratio $0.97 \pm 0.03$ ), IS of mesoscutum with distinct tessellation over entire surface, and metasomal terga with enamel-like luster as in most species of Lasioglossum.

\section{Material examined}

\section{Paratypes}

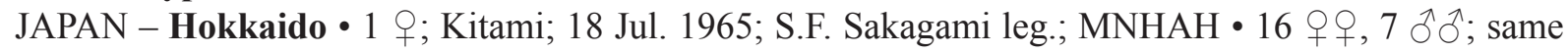
location as for preceding; 22 Jul.-14 Aug. 1964; S.F. Sakagami leg.; MNHAH • 3 q $O$; same location as 
for preceding; 14 Aug. 1964; S.F. Sakagami leg.; MNNAH・6 $Q$, 2 ふふ; same location as for preceding; 23 Aug. 1959; S.F. Sakagami leg.; MNHAH • 1 ठ̊̄; Kitamoshiri, Hokkaido Uryu Experimental Forest;

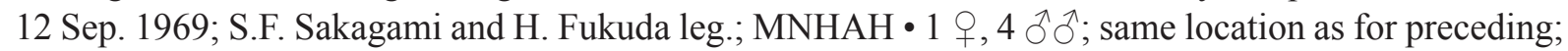
14 Sep. 1969; S.F. Sakagami and H. Fukuda leg.; MNHAH.

\section{Other material}

JAPAN - Hokkaido • 1 क; Mt Daisetsu, Aizankei; 30 Jul.-3 Aug. 1955; Y. Hirashima leg.; ELKU • 1 9; Asahikawa, Asahiyama; 18 Jun. 1985; T. Inaoka leg.; MNHAH • 1 क; Sapporo, Barato; 3 Jun. 1973; M. Matsumoto leg.; MNHAH • 1 क; same location as for preceding; 7 Jun. 1973; M. Matsumoto leg.; MNHAH • 1 क; same location as for preceding; 14 Jun. 1973; M. Matsumoto leg.; MNHAH • 7 우; same location as for preceding; 21 Jun. 1973; M. Matsumoto leg.; MNHAH $\bullet 12$ q $Q$; same location as for preceding; 28 Jun. 1973; M. Matsumoto leg.; MNHAH • 1 क; same location as for preceding; 27 Jul. 1973; M. Mastumoto leg.; MNHAH • 2 우; same location as for preceding; 3 Aug. 1973; M. Matsumoto leg.; MNHAH • 1 O; same location as for preceding; 8 Aug. 1973; M. Matsumoto leg.; MNHAH $\bullet 1$ \%; Fukushima; 27 Jul. 1965; M. Munakata leg.; MNHAH • 1 q; Asahikawa, Inosawa; 30 May 1969; MNHAH • 4 Q $\odot$; same location as for preceding; 25 Jun. 1969; MNHAH • 6 + $O$; same location as for preceding; 27 Jun. 1969; MNHAH • 14 q ; same location as for preceding; 13 Jul. 1969; MNHAH • 1 ; ; same location as for preceding; 15 Jul. 1969; MNHAH 11 ; same location as for preceding; 15 Aug. 1969; MNHAH • 2 우; same location as for preceding; 29 May 1970; MNHAH • 14 우; same location as for preceding; 10 Jun. 1970; MNHAH • 7 q ; ; Nokanan; 8 Jun. 1967; MNHAH $\bullet 6$ q ; same location as for preceding; 22 Jun. 1967; MNHAH • 1 \%; same location as for preceding; 27 Jun. 1967; MNHAH • 1 क; same location as for preceding; 6 Jul. 1967; MNHAH • 17 q $q$; same location as for preceding; 21 Jul. 1967; MNHAH • 3 우; Sapporo, Hokkaido University Campus; 6 Jun. 1959; S.F. Sakagami leg.; MNHAH • 1 ; same location as for preceding; 11 Jun. 1959; S.F. Sakagami leg.; MNHAH • 1 क; same location as for preceding; 14 Jun. 1959; S.F. Sakagami leg.; MNHAH • 2 우; same location as for preceding; 18 Jun. 1959; S.F. Sakagami leg.; MNHAH $\bullet 4$ $Q$; ; same location as for preceding; 30 Jun. 1959; S.F. Sakagami leg.; MNHAH • 1 \%; Yukomanbetsu; 22 Jul. 1967; MNHAH • 1 क ; same location as for preceding; 4 Jul. 1968; MNHAH • 1 J; Ebetsubuto; 18 Jul. 1974; M. Ishikawa leg.; MNHAH. - Honshu • 1 क; Aomori Pref., Mt Iwaki; 5 Oct. 1980; M. Yamada leg.; MNHAN • 1 \%; same location as for preceding; 14 Jul. 1981; M. Yamada leg.; MNHAH • 1 क ; Miyagi Pref., Shiogamashi, Hojima; 19 May 1995; K. Gôukon leg.; cGou • 1 q; same location as for preceding; 25 May 1996; K. Gôukon leg.; cGou • 1 q; Niigata Pref., Sado Is., Dondenyama; 9 Jul. 1999; K. Gôkon leg.; cGou •

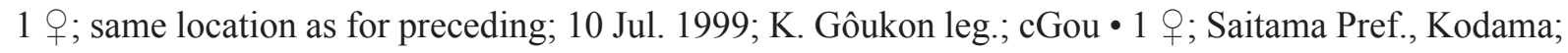
6 Jun. 1968; T. Nambu leg.; ELKU • 4 क 9 ; same location as for preceding; 3 Jul. 1968; T. Nambu leg.; ELKU • 1 क; Nagano Pref., Yamaguchi-mura, Magome; 15 May 1975; O. Tadauchi leg.; ELKU • 5 우; Gifu Pref., Hikie; 5 Jun. 1978; K. Yamauchi leg.; MNHAH • 3 क ; same location as for preceding; 28 Jun. 1978; K. Yamauchi leg.; MNHAH • 1 O; Wakayama Pref., Kibi; 2 Apr. 1969; M. Matsuura leg.; MNHAH • 1 क; same location as for preceding; 26 May 1969; M. Matsuura leg.; MNHAH • 1 ; Yamaguchi Pref., Toyoda-machi, Houra; 12 May 2004; T. Sugimoto leg.; cMur. - Kyushu • 5 q $ᄋ$; Fukuoka Pref., Mt Wakasugi-yama; 22 Apr. 1973; O. Tadauchi leg.; ELKU • 1 क; Oita Pref., Kokonoemachi, Jizoubaru; 1 Nov. 1970; K. Kanmiya leg.; ELKU • 2 우; Oita Pref., Kusu-gun, Kokonoemachi, Handakougen; 5 Jun. 2004; T. Sugimoto leg.; cMur • 1 क; Oita Pref., Kusu-gun, Kokonoe-machi, Chojyabaru; 337'6.773" N, 131¹3'49.331" E; 1050 m a.s.1.; 13 Aug. 2010; R. Murao leg.; cMur • 3 우; same location as for preceding; 14 Aug. 2010; R. and Y. Murao leg.; cMur • 1 क; same location as for preceding; 5 Sep. 2010; Y. Murao leg.; cMur $\bullet 8$ + $\odot$; same location as for preceding; 15 May 2011; R. and Y. Murao leg.; cMur • 3 q $ᄋ$; same location as for preceding; 12 Aug. 2011; R. Murao leg.; cMur • 1 \%; same location as for preceding; 28 Aug. 2011; R. Murao leg.; cMur • 1 ; ; same location as for preceding; 5 Aug. 2013; R. Murao leg.; ELKU • 2 ㅇ; Kumamoto Pref., Aso-gun, Aso-machi,

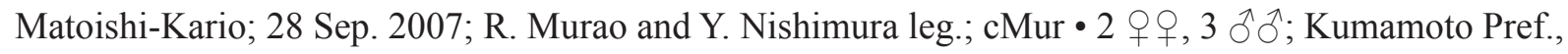


Aso-gun, Aso-machi, near Mt Komezuka; 23 Jul. 2004; R. Murao and T. Sugimoto leg.; cMur • 1 ; ; Kumamoto Pref., Aso-gun, Choyou-son, Kawayou; 26 May 2004; T. Sugimoto leg.; cMur.

\section{Distribution}

Japan (Hokkaido, Honshu, Kyushu, northern Ryukyus).
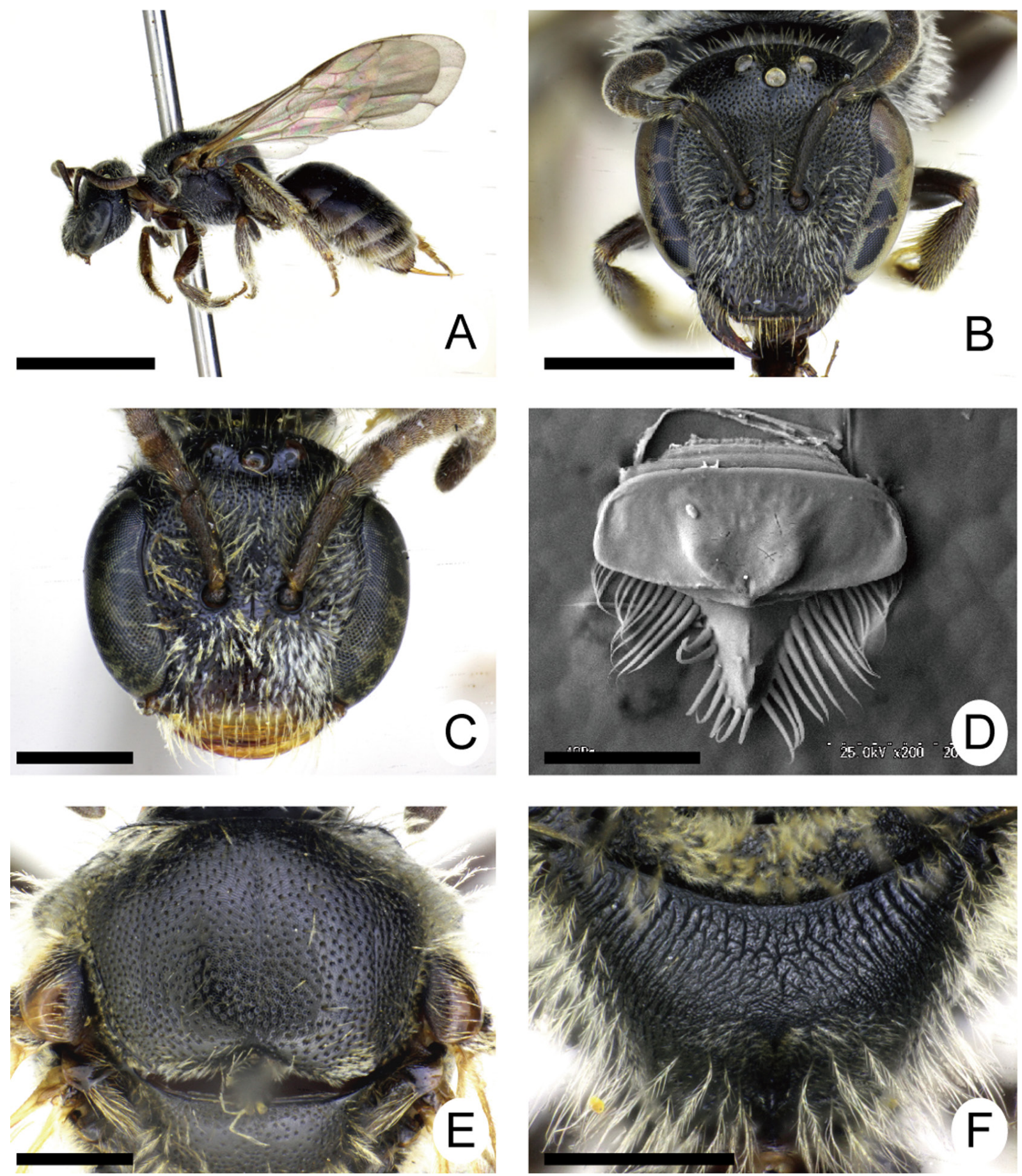

Fig. 7. Lasioglossum (Hemihalictus) ohei Hirashima \& Sakagami, 1966. A. + , lateral habitus. B. + , head in frontal view. C. $O^{\lambda}$, head in frontal view. D. + , labrum. E. + , mesoscutum. F. $q$, metapostnotum. Scale bars: $A=2 \mathrm{~mm} ; \mathrm{B}=1 \mathrm{~mm} ; \mathrm{C}, \mathrm{E}-\mathrm{F}=0.5 \mathrm{~mm} ; \mathrm{D}=0.2 \mathrm{~mm}$. 


\section{Flight period}

Female: April to November.

Male: July to September. The flight records of males are based on the paratypes collected or reared from the nest (Sakagami et al. 1966).

\section{Flower records}

The specimens examined in this paper were collected on the flowers of 50 species in 19 families as follows. Amaryllidaceae: Allium fistulosum L. Apiaceae: Sanicula chinensis Bunge. Asteraceae: Achillea alpina L. var. longiligulata H.Hara; Aster microcephalus (Miq.) Franch. \& Sav. var. ovatus (Franch. \& Sav.) Soejima \& Mot.Ito; Erigeron annuus (L.) Pers.; Eupatorium glehnii F.Schmidt ex Trautv.; Ixeridium dentatum (Thunb.) Tzvelev subsp. dentatum; Leontodon taraxacoides (Vill.) Mérat; Picris hieracioides L. subsp. japonica (Thunb.) Krylov; Pterocypsela elata (Hemsl.) C.Shih; Sonchus sp.; Taraxacxum sp. Brassicaceae: Brassica rapa L. var. glabra Regel 'Pe-tsai'; Brassica rapa L. var. oleifera DC.; Brassica rapa L. var. rapa; Capsella bursa-pastoris (L.) Medik.; Raphanus sativus L. var. hortensis Backer; Thlaspi arvense L. Campanulaceae: Lobelia sessilifolia Lamb. Commelinaceae: Commelina communis L. Convolvulaceae: Calystegia pubescens Lindl. Fabaceae: Trifolium pratense L.; Trifolium repens L. Gentianaceae: Gentiana zollingeri Fawc. Hydrangeaceae: Deutzia scabra Thunb.; Hydrangea macrophylla (Thunb.) Ser. f. macrophylla; Hydrangea serrata (Thunb.) Ser. var. serrata. Hypericaceae: Hypericum patulum Thunb. Iridaceae: Iris sanguinea Hornem. Lamiaceae: Prunella vulgaris L. subsp. asiatica (Nakai) H.Hara. Paeoniaceae: Paeonia suffruticosa Andrews. Papaveraceae: Chelidonium majus L. subsp. asiaticum H.Hara; Hylomecon japonica (Thunb.) Prantl \& Kündig. Polygonaceae: Persicaria filiformis (Thunb.) Nakai ex W.T.Lee; Persicaria longiseta (Bruijn) Kitag. Ranunculaceae: Ranunculus cantoniensis DC.; Ranunculus chinensis Bunge; Ranunculus japonicus Thunb.; Ranunculus repens L. Rosaceae: Filipendula multijuga Maxim.; Geum japonicum Thunb.; Malus pumila Mill.; Potentilla fragarioides L. var. major Maxim.; Potentilla freyniana Bornm.; Rosa multiflora Thunb.; Rosa rugosa Thunb.; Rosa sp.; Rubus parvifolius L. Saururaceae: Houttuynia cordata Thunb.

\section{Habitat}

This species has been collected mainly from the mountain of western Japan. One of the collecting sites is shown in Fig. 19A.

\section{Biological reference}

Sakagami et al. (1966) and Sakagami (1992) reported on the biology of this species as univoltine and communal, with nest structure type Ia of Sakagami \& Michener (1962).

Lasioglossum (Hemihalictus) simplicior (Cockerel1, 1931)

Figs 2D, 8, 15E, 17D

Halictus simplicior Cockerell, 1931: 16 (holotype: AMNH,, , type locality=Shanghai, China, examined).

Lasioglossum (Evylaeus) simplicior - Ebmer 1978b: 316; 1980: 503; 1996: 293. — Takahashi \& Sakagami 1993: 275.

Evylaeus (Prosopalictus) simplicior - Pesenko 2007b: 111.

\section{Diagnosis}

Females are similar to $L$. $(H$.) ohei, but separated from them by the head wider than long (HL/HW ratio $0.97 \pm 0.03)$, IS of mesoscutum with distinct tessellation over entire surface, and metasomal terga with enamel-like luster. In contrast, in $L$. (H.) ohei, the head is slightly longer than wide or nearly as long as wide (HL/ HW ratio $1.01 \pm 0.02$ ), IS of mesoscutum nearly smooth on posterior margin, and metasomal terga with silky dull luster. 


\section{Material examined}

Holotype

CHINA • +; Prov. Kiangsu, Shanghai, Zô-Sè; AMNH.

\section{Other material}

JAPAN - Izu Islands • 44 q $O$; Hachijo Is., Okago-Fuji; 26 May 1964; Y. Hirashima and M. Shiga

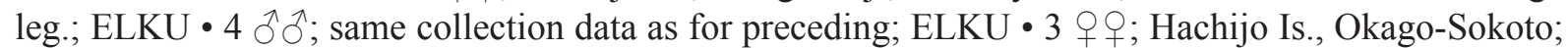
5 Jun. 1964; Y. Hirashima and M. Shiga leg.; ELKU $\bullet 1$ ô; same collection data as for preceding; ELKU • 2 ㅇ; Mt Kanto-yama, Hachijo Is.; 2 Jun. 1964; Y. Hirashima and M. Shiga leg.; ELKU • 1 ơ; same collection data as for preceding; ELKU • 1 \%; Hachijo Is., Kamogawa; 27 May 1964; Y. Hirashima and M. Shiga leg.; ELKU • 2 $\delta$; same collection data as for preceding; ELKU 15 우 0 ;

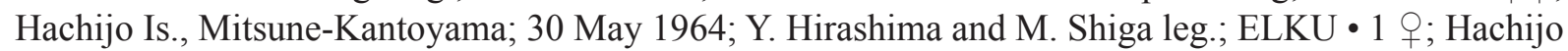
Is., Hachijo Fuji; 31 May 1964; Y. Hirashima and M. Shiga leg.; ELKU • 1 q; Hachijo Is., Eigo; 2 Jun. 1964; Y. Hirashima and M. Shiga leg.; ELKU • 1 万ิ; same collection data as for preceding; ELKU • 1 ${ }^{\lambda}$; same location as for preceding; 15 Aug. 1987; H. Takahashi leg.; ELKU • 1 क; same location as for preceding; 26 Sep. 1987; H. Takahashi leg.; MNHAH • 1 q; same location as for preceding; 4 Oct. 1987; H. Takahashi leg.; MNHAH • 1 đ; Hachijo Is., Mt Mitsune-yama, Nakanogo-Daigo; 1 Jun. 1964; Y. Hirashima and M. Shiga leg.; ELKU • 1 O; Hachijo Is., Bouei Road; 27 Sep. 1987; H. Takahashi

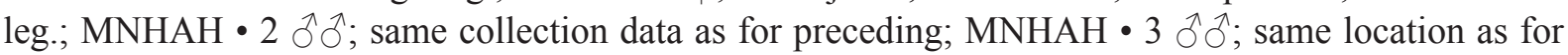
preceding; 3 Oct. 1987; H. Takahashi leg.; ELKU • 1 q; Hachijo Is., Okago; 10 Jul. 1987; H. Takahashi leg.; MNHAH • 1 §; Hachijo Is., Sokoto; 4 Jun. 1964; Y. Hirashima and M. Shiga leg.; ELKU • 1 \%; Tokyo, Aoga Is., Yasundogou; 10 Aug. 1987; H. Takahashi leg.; MNHAH.

\section{Redescription}

\section{Female}

Measurements $(\mathrm{n}=6$, unit $\mathrm{mm}) . \mathrm{BL}=5.25-5.75(5.41 \pm 0.24), \mathrm{WL}=3.85-5.25(4.81 \pm 0.52), \mathrm{HL}=1.48-$ $1.58(1.54 \pm 0.05), \mathrm{HW}=1.52-1.68(1.59 \pm 0.07), \mathrm{IOD}=0.22-0.31 \quad(0.27 \pm 0.03), \mathrm{OOD}=0.26-0.33$ $(0.28 \pm 0.03), \quad \mathrm{OCD}=0.13-0.21 \quad(0.18 \pm 0.03), \quad \mathrm{UOD}=0.97-1.03 \quad(1.01 \pm 0.02), \quad \mathrm{MOD}=1.09-1.23$ $(1.16 \pm 0.06), \mathrm{LOD}=0.82-0.94(0.88 \pm 0.05), \mathrm{IAD}=0.16(0.16 \pm 0.00), \mathrm{AOD}=0.27-0.32(0.29 \pm 0.02)$, $\mathrm{CAL}=0.22-0.31(0.28 \pm 0.03), \mathrm{CPL}=0.32-0.35(0.34 \pm 0.01), \mathrm{EL}=1.09-1.85(1.66 \pm 0.29), \mathrm{EW}=0.39-$ $0.45(0.42 \pm 0.02), \quad \mathrm{GW}=0.29-0.35 \quad(0.33 \pm 0.02), \quad \mathrm{SPL}=0.60-0.66 \quad(0.64 \pm 0.02), \quad \mathrm{F} 1 \mathrm{~L}=0.07-0.10$ $(0.09 \pm 0.01), \mathrm{F} 2 \mathrm{~L}=0.07-0.08(0.08 \pm 0.01), \mathrm{F} 3 \mathrm{~L}=0.08-0.10(0.09 \pm 0.01), \mathrm{F} 2 \mathrm{~W}=0.11-0.15(0.13 \pm 0.01)$, $\mathrm{MsW}=1.71-2.00 \quad(1.88 \pm 0.12), \quad \mathrm{SCL}=0.31-0.43 \quad(0.39 \pm 0.05), \quad \mathrm{MNL}=0.22-0.28 \quad(0.25 \pm 0.02)$, $\mathrm{MPL}=0.24-0.28(0.26 \pm 0.01), \mathrm{MtW}=1.75-2.05(1.90 \pm 0.11)$.

Coloration. Body black except for the following parts: mandible reddish brown apically; flagellum blackish brown ventrally; tegula yellowish brown translucent; tibial spur yellow; metasomal terga broadly yellowish brown translucent apically. Wings transparent, veins and stigma yellowish brown.

PubesCENCE. Body hairs whitish, and covered with erect and sparse straight or fine branched hairs except for the following parts: pronotum moderately densely tomentose on dorsal area and around lobe; hind trochanter, femur, and tibia mixed with plumose hairs, forming scopa.

STRUCTURE AND SCULPTURE HEAD. Wider than long or nearly as long as wide; $\mathrm{HW}: \mathrm{HL}=1: 0.97$. Vertex rounded in frontal view. MOD:UOD:LOD=1:0.87:0.76. IOD:OOD:OCD=1:1.05:0.68. IAD:AOD=1:1.84. Ocellocular and paraocular areas, frons weakly shiny, with shallow reticulate PP. Supraclypeal area slightly convex, dull, with dense PP, IS distinctly tessellate (IS=0.5-2 d). CPL:CAL=1:0.82. Clypeus nearly flat, with dense PP on upper half and larger shallow PP on lower half, IS nearly smooth (IS $=0.5$ $1 \mathrm{~d}$ on upper half). EW:GW=1:0.78. Genal area with weak straight ridges. Malar space linear. Occiput not carinate. Postgena distinctly tessellate. Hypostomal carinae nearly parallel. Mandible bidentate. 
Labrum (Fig. 8D): basal area approximately $2.2 \times$ as wide as long; distal process approximately $0.7 \times$ as long as basal area, narrow, and without lateral projection; distal keel pointed apically. Antenna short, not reaching metasoma. F2L:F2W=1:1.71; flagellum nearly flattened ventrally.

THOARx. Dorsolateral angle of pronotum obtuse; lateral surface without ridges; lateral lobe rounded. Tegula ovoid, nearly smooth. Mesoscutum (Fig. 8E) with dense PP over entire surface; IS distinctly tessellate over entire surface (IS=0.5-2 d); parapsidal line a narrow groove. Mesoscutellum with dense PP over entire surface, IS with weak tessellation (IS $=0.5-2 \mathrm{~d}$ ). Metanotum weakly rugulose. Mesepisternum weakly shiny, with reticulate PP over entire surface. SCL:MNL:MPL=1:0.63:0.65. Propodeum: metapostnotum (Fig. 8F) gently inclined, with irregular sinuate ridges nearly attaining to posterior margin; junction between metapostnotum and posterior surface not carinate; lateral surface weakly rugulose; posterior surface with lateral carina on lower $2 / 3$, without oblique carina. Coxae usual shape, without tubercle. Fore trochanter narrow, longer than wide. Basitibial plate of hind leg carinate marginally. Inner hind tibial spur with slender $2-5$ teeth $(n=50)$. Fore wing with three submarginal cells.

Abdomen.Disc of T1 with SParse fine PP on medial area AND Lineolation over entire suRface (Fig. 15E). Lineolation on T2-T5 nearly over entire surface.

\section{First description of male}

MEASUREMENTS ( $\mathrm{n}=5$, unit $\mathrm{mm}) . \mathrm{BL}=4.38-5.62(4.94 \pm 0.41), \mathrm{WL}=3.92-5.15(4.37 \pm 0.43), \mathrm{HL}=1.44-$ $1.49(1.45 \pm 0.02), \mathrm{HW}=1.51-1.62(1.56 \pm 0.04), \quad \mathrm{IOD}=0.27-0.29 \quad(0.28 \pm 0.02), \quad \mathrm{OOD}=0.29-0.31$ $(0.30 \pm 0.01), \quad \mathrm{OCD}=0.20-0.22 \quad(0.21 \pm 0.01), \quad \mathrm{UOD}=0.98-1.04 \quad(1.02 \pm 0.03), \quad \mathrm{MOD}=1.04-1.11$ $(1.08 \pm 0.03), \quad \mathrm{LOD}=0.80-0.91 \quad(0.85 \pm 0.05), \quad \mathrm{IAD}=0.20-0.22 \quad(0.20 \pm 0.01), \quad \mathrm{AOD}=0.22-0.24$ $(0.24 \pm 0.01), \mathrm{CAL}=0.22-0.24(0.24 \pm 0.01), \mathrm{CPL}=0.31-0.38(0.34 \pm 0.02), \mathrm{EL}=1.07-1.11(1.08 \pm 0.02)$, $\mathrm{EW}=0.44-0.49(0.46 \pm 0.02), \mathrm{GW}=0.36-0.44(0.40 \pm 0.03), \mathrm{SPL}=0.42-0.44(0.44 \pm 0.01), \mathrm{F} 1 \mathrm{~L}=0.11$ $(0.11 \pm 0.00), \mathrm{F} 2 \mathrm{~L}=0.16-0.18(0.17 \pm 0.01), \mathrm{F} 3 \mathrm{~L}=0.16-0.18(0.17 \pm 0.01), \mathrm{F} 2 \mathrm{~W}=0.11-0.13(0.13 \pm 0.01)$, $\mathrm{MsW}=1.39-1.55 \quad(1.47 \pm 0.05), \quad \mathrm{SCL}=0.36-0.38 \quad(0.36 \pm 0.01), \quad \mathrm{MNL}=0.18-0.20 \quad(0.18 \pm 0.01)$, $\mathrm{MPL}=0.22(0.22 \pm 0.00), \mathrm{MtW}=1.19-1.32(1.24 \pm 0.05)$.

Coloration. Body black except for the following parts: mandible yellow except for apically reddish; labrum and lower half of clypeus yellow; flagellum yellowish brown ventrally; tegula yellowish brown translucent; tibiae basally and apically yellow; tibial spur yellow; tarsi yellow; metasomal terga broadly yellowish brown translucent apically. Wings transparent, veins and stigma pale yellowish brown.

PubEsCence. Body hairs whitish, and covered with erect and sparse straight or fine branched hairs except for the following parts: lower paraocular area sparsely tomentose.

Structure and sculpture head. Wider than long; HW:HL=1:0.93. Vertex rounded in frontal view. MOD:UOD:LOD=1:0.94:0.78. IOD:OOD:OCD $=1: 1.06: 0.73$. IAD:AOD $=1: 1.11$. Ocellocular and paraocular areas, frons weakly shiny, with shallow reticulate PP. Supraclypeal area nearly flat, dull, with reticulate PP, IS distinctly tessellate. $\mathrm{CPL}: \mathrm{CAL}=1: 0.71$. Clypeus nearly flat, with dense PP over entire surface, IS smooth (IS $=0.5-1 \mathrm{~d})$. EW:GW=1:0.88. Genal area with weak straight ridges. Malar space linear. Occiput not carinate. Postgena distinctly lineolate. Hypostomal carinae nearly parallel. Mandible edentate. Antenna short, not reaching metasoma. F2L:F2W=1:0.74; flagellum nearly flattened ventrally.

THOARX. Dorsolateral angle of pronotum obtuse; lateral surface without ridges; lateral lobe rounded. Tegula ovoid, nearly smooth. Mesoscutum with dense PP over entire surface; IS weakly tessellate on anterior margin, otherwise smooth (IS $=0.5-2 \mathrm{~d}$ ); parapsidal line a narrow groove. Mesoscutellum with moderately dense over entire surface, IS smooth (IS=0.5-3 d). Metanotum weakly rugulose. Mesepisternum weakly shiny, with reticulate PP over entire surface. SCL:MNL:MPL=1:0.50:0.61. Propodeum: metapostnotum gently inclined, with longitudinal ridges on anterior $2 / 3$, not reaching 
posterior margin; junction between metapostnotum and posterior surface not carinate and nearly smooth; lateral surface weakly rugulose; posterior surface with lateral carina on lower half, without oblique carina. Coxae usual shape, without tubercle. Fore trochanter narrow, longer than wide. Basitibial plate of hind leg carinate marginally. Inner hind tibial spur serrate. Fore wing with three submarginal cells.

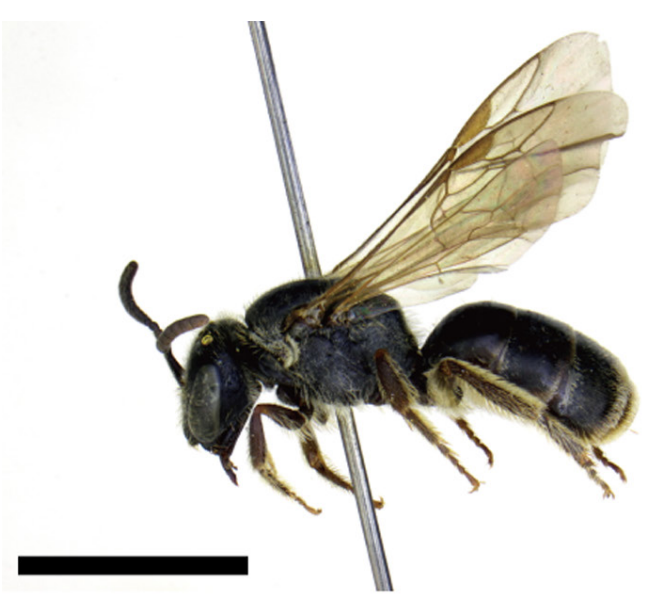

A
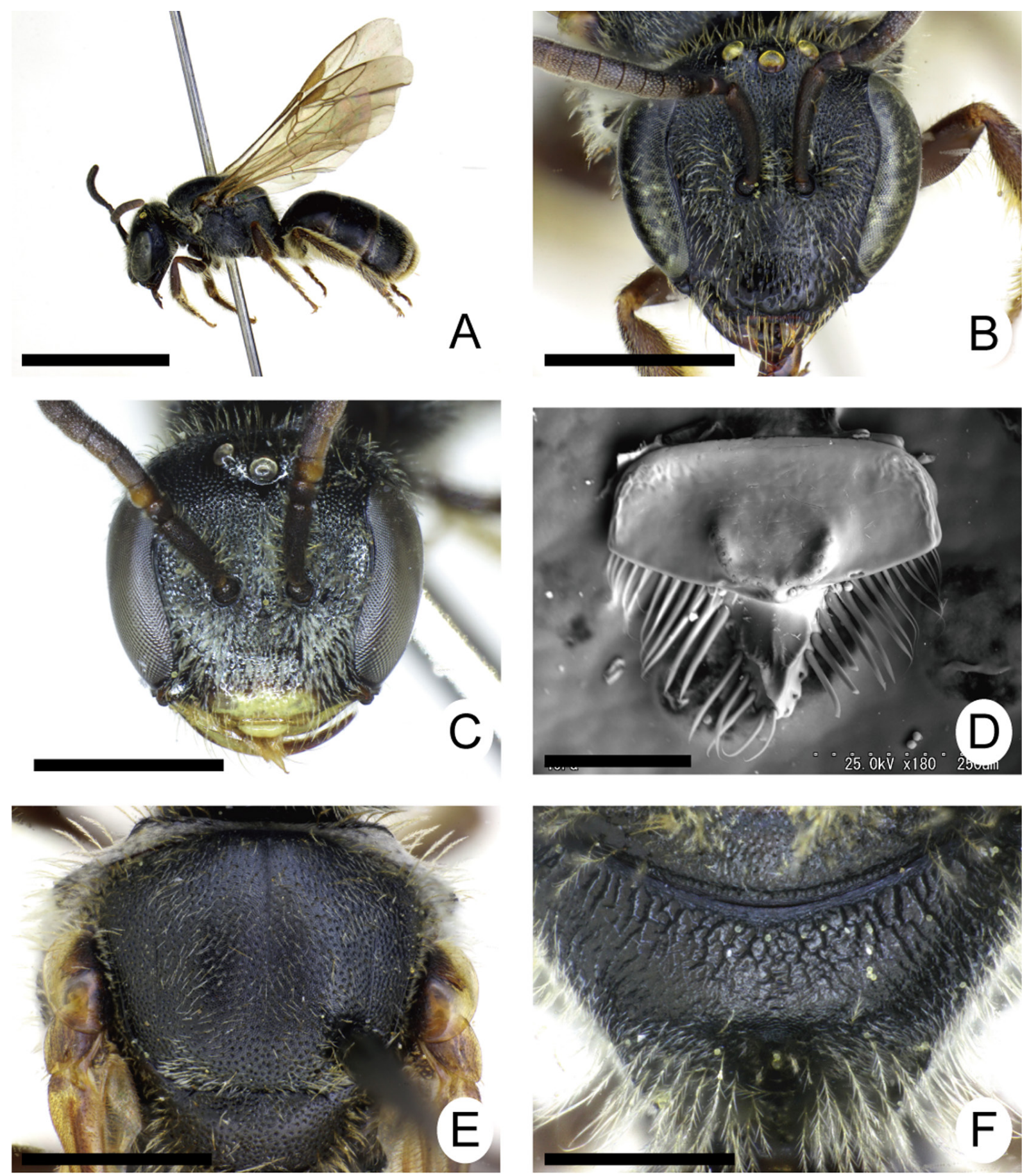

Fig. 8. Lasioglossum (Hemihalictus) simplicior (Cockerell, 1931). A. $\odot$, lateral habitus. B. $\circ$, head in frontal view. C. $\hat{O}$, head in frontal view. D. $q$, labrum. E. + , mesoscutum. F. + , metapostnotum. Scale bars: $\mathrm{A}=3 \mathrm{~mm}$; $\mathrm{B}-\mathrm{C}=1 \mathrm{~mm}$; $\mathrm{D}=0.25 \mathrm{~mm} ; \mathrm{E}-\mathrm{F}=0.5 \mathrm{~mm}$. 
AbDomen. Disc of T1 with sparse fine PP and without lineolation. Disc of T2-T3 with denser PP than T1; T2 without lineolation, and T3 posteriorly with weak lineolation. T4 with weak lineolation over entire surface. S7 with moderately long, apically rounded median process.

Genitalia. Gonobase flat at bottom; gonocoxite smooth; ventral retrorse lobe tongue-like, moderately long reaching gonobasal ventral arm, with sparse short hairs ventrally.

\section{Distribution}

Japan (Izu-shotô Islands: Hachijo-jima Is., Aoga-shima Is.), Korean Peninsula, Russian Far East, China.

\section{Flight period}

Female: late May to early October.

Male: late May to middle October.

\section{Flower record}

Hydrangea macrophylla (Thunb.)Ser. (Hydrangeaceae).

\section{Comments}

The type locality of this species is Shanghai in China, so it is not surprising that L. simplicior is also distributed on the Japanese mainland. Interestingly, Japanese specimens matching the holotype were found only on the Izu Islands and not on the Japanese mainland. In the future, it may be worth while to verify whether the population of the Izu Islands indeed represents L. simplicior, after comparison of the genes of both the continental and Izu Islands populations.

This species has been recorded from Japan (Takahashi \& Sakagami 1993; Goubara et al. 2004; Fukasawa \& Miyano 2010). However, these records were excluded from the Japanese bee fauna because of the need to re-examine them (Tadauchi \& Murao 2014; Murao 2020). In the present study, the distribution of this species in Japan was reconfirmed by comparing with the type specimen.

\section{Lasioglossum (Hemihalictus) smilodon Ebmer \& Sakagami, 1994} Figs 9, 15F, 18D, 20E

Lasioglossum (Evylaeus) smilodon Ebmer \& Sakagami in Ebmer et al., 1994: 32, figs 26-33 (†ð) (holotype: ELKU, + , type locality=(TOKARA) Suwanose-Jima, Kagoshima Pref., Japan, examined).

Lasioglossum (Evylaeus) smilodon - Sakagami \& Ebmer 1996: figs 1c, 3c, 4c, 5b, 6a (우). — Murao et al. 2010: 31-32 (in key).

\section{Diagnosis}

Females are similar to L. (H.) ikudomei sp. nov. but are separated from them by the supraclypeal area dimly shiny (IS distinctly tessellate), the PP on the mesoscutum denser (IS $=2 \mathrm{~d}$ in maximum) (Fig. 9E), and the lineolation of T1 more clear. In contrast, in L. (H.) ikudomei sp. nov., the supraclypeal area is more shiny (IS weakly tessellate), the PP on the mesoscutum sparser (IS $=3 \mathrm{~d}$ in maximum) (Fig. 5E), and T1 with very weak lineolation.

\section{Material examined}

Holotype

JAPAN - Ryukyus • क; Kagoshima Pref., Suwanose-jima; 2 Aug. 1985; S. Ikudome leg.; ELKU. 


\section{Paratype}

JAPAN - Ryukyus • 1 đ̊; Kagoshima Pref., Akuseki-jima; 150-230 m a.s.1.; 2 Aug. 1985; S. Ikudome leg.; KWC.
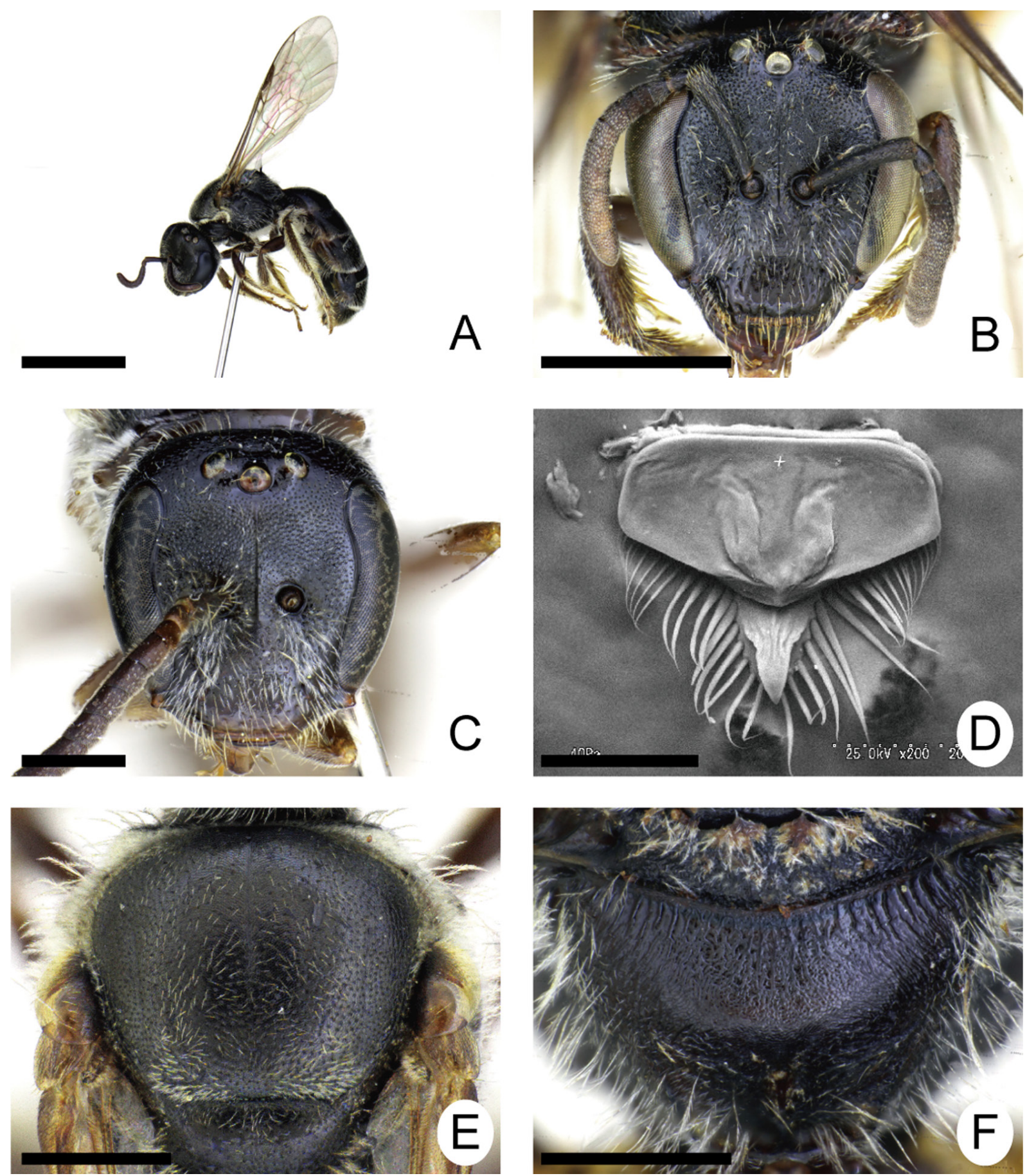

Fig. 9. Lasioglossum (Hemihalictus) smilodon Ebmer \& Sakagami, 1994. A. , , lateral habitus. B. + , head in frontal view. C. $O^{\lambda}$, head in frontal view. D. + , labrum. E. + , mesoscutum. F. $q$, metapostnotum. Scale bars: $A=2 \mathrm{~mm} ; \mathrm{B}=1 \mathrm{~mm} ; \mathrm{C}, \mathrm{E}-\mathrm{F}=0.5 \mathrm{~mm} ; \mathrm{D}=0.2 \mathrm{~mm}$. 


\section{Other material}

JAPAN - Ryukyus • 1 q; Kagoshima Pref., Iwo-jima; 1 May 2011; T. Kawano leg.; cMur • 1 \%; Kagoshima Pref., Ôsumi Is., Kuchinoerabu-jima; 21 Jul. 1989; H. Watanabe leg.; KWC・1 ; Kagoshima Pref., Kuroshima Is., Osato; 4 Sep. 1981; Sk. Yamane leg.; KWC • 1 §̊; Kagoshima Pref., Osumi-shotô, Yakushima, Issô; 30 Jul. 1988; Sk. Yamane leg.; KWC • 2 + ; Kagoshima Pref., Tokara Islands, Takarajima Isl., Oogomori; 31 May-4 Jun. 2005; T. Mita leg., yellow pan trap; cMur • 1 क ; Kagoshima Pref., Tokara Islands, Nakano-shima, Mt On-take; 7 Jun. 2005; T. Mita leg.; cMur • 1 क ; Kagoshima Pref., Tokara, Nakano-shima, Ikenobaru; 220 m a.s.l.; 14 Oct. 1985; S. Ikudome leg.; KWC• 1 q; Kagoshima Pref., Tokara Islands, Nakano-shima, Toshima; 21 Jun. 1973; H. Makihara leg.; ELKU• 1 §’; Kagoshima Pref., Tokara, Suwanose-jima; 50-120 m a.s.1.; 31 Jul. 1985; S. Ikudome leg.; KWC.

\section{Redescription}

\section{Female}

Measurements ( $\mathrm{n}=5$, unit $\mathrm{mm}) . \mathrm{BL}=4.88-5.75(5.48 \pm 0.35), \mathrm{WL}=4.50-5.13(4.80 \pm 0.24), \mathrm{HL}=1.48-$ $1.68(1.59 \pm 0.07), \mathrm{HW}=1.45-1.61(1.55 \pm 0.06), \mathrm{IOD}=0.26-0.29 \quad(0.28 \pm 0.01), \mathrm{OOD}=0.24-0.26$ $(0.25 \pm 0.01), \quad \mathrm{OCD}=0.19-0.24 \quad(0.21 \pm 0.02), \quad \mathrm{UOD}=0.87-1.00 \quad(0.95 \pm 0.05), \quad \mathrm{MOD}=1.03-1.18$ $(1.13 \pm 0.06), \quad \mathrm{LOD}=0.77-0.90 \quad(0.86 \pm 0.05), \quad \mathrm{IAD}=0.13-0.16 \quad(0.15 \pm 0.01), \quad \mathrm{AOD}=0.26-0.31$ $(0.28 \pm 0.02), \mathrm{CAL}=0.27-0.29(0.28 \pm 0.01), \mathrm{CPL}=0.32-0.35(0.34 \pm 0.01), \mathrm{EL}=1.60-1.85(1.79 \pm 0.11)$, $\mathrm{EW}=0.39-0.45(0.41 \pm 0.03), \mathrm{GW}=0.29-0.35(0.34 \pm 0.03), \mathrm{SPL}=0.63-0.66(0.65 \pm 0.01), \mathrm{F} 1 \mathrm{~L}=0.08-$ $0.10(0.09 \pm 0.01), \quad \mathrm{F} 2 \mathrm{~L}=0.08-0.11 \quad(0.09 \pm 0.01), \quad \mathrm{F} 3 \mathrm{~L}=0.08-0.10 \quad(0.08 \pm 0.01), \quad \mathrm{F} 2 \mathrm{~W}=0.11-0.15$ $(0.13 \pm 0.01), \quad \mathrm{MsW}=1.75-2.05 \quad(1.92 \pm 0.12), \quad \mathrm{SCL}=0.38-0.43 \quad(0.41 \pm 0.02), \quad \mathrm{MNL}=0.23-0.28$ (0.26 \pm 0.02$), \mathrm{MPL}=0.28-0.33(0.31 \pm 0.02), \mathrm{MtW}=1.80-2.15(2.00 \pm 0.14)$.

Coloration. Body black except for the following parts: mandible reddish brown apically; F4-F10 yellowish brown ventrally; tegula yellowish brown translucent; tibial spur yellow; metasomal terga narrowly yellowish brown translucent apically. Wings transparent, veins and stigma blackish brown.

PuBESCENCE. Body hairs whitish, and covered with erect and sparse straight or fine branched hairs except for the following parts: pronotal dorsum to lobe and metanotum densely tomentose; hind trochanter, femur, and tibia mixed with plumose hairs, forming scopa. Disc of T1 without short hairs. Discs of T2T4 with moderately dense short hairs over entire surface.

Structure And Sculpture HEAD. Nearly as long as wide; HW:HL $=1: 1.02$. Vertex rounded in frontal view. MOD:UOD:LOD=1:0.84:0.76. IOD:OOD:OCD =1:0.88:0.76. IAD:AOD=1:1.91. Ocellocular area moderately densely puctate, IS smooth (IS $=1-2.5 \mathrm{~d}$ ). Paraocular area and frons weakly shiny, with shallow reticulate PP. Supraclypeal area slightly convex, weakly shiny, with dense PP, IS weakly tessellate (IS $=1-1.5$ d). CPL:CAL=1:0.83. Clypeus nearly flat, with dense PP on upper half and larger shallow PP on lower half; IS weakly tessellate on upper half and nearly smooth on lower half (IS $=1-2 \mathrm{~d}$ on upper half). EW:GW=1:0.81. Genal area to postgena with straight ridges. Malar space linear. Occiput not carinate. Hypostomal carinae nearly parallel. Mandible bidentate. Labrum (Fig. 9D): basal area approximately $1.9 \times$ as wide as long; distal process approximately $0.6 \times$ as long as basal area, narrow, and without lateral projection; distal keel pointed apically. Antenna short, not reaching metasoma. F2L:F2W=1:1.48; flagellum nearly flattened ventrally.

THORAX. Dorsolateral angle of pronotum obtuse; lateral surface without ridges; lateral lobe rounded. Tegula ovoid, nearly smooth. Mesoscutum (Fig. 9E) with dense PP over entire surface; IS distinctly tessellate over entire surface (IS $=0.5-2 \mathrm{~d}$ ); parapsidal line a narrow groove. Mesoscutellum with sparser PP on submedian area and denser PP on marginal area; IS weakly tessellate over entire surface (IS $=1-4 \mathrm{~d}$ on submedian area, and $0.5-2 \mathrm{~d}$ on marginal area). Metanotum weakly rugulose. Mesepisternum shallow reticulate-punctate on upper area and weakly rugulae on lower area. SCL:MNL:MPL=1:0.63:0.74. 
Propodeum: metapostnotum (Fig. 9F) dimly shiny and gently inclined, with straight ridges occupying anterior half, and distinctly tessellate on posterior half; junction between metapostnotum and posterior surface not carinate, distinctly tessellate; lateral surface distinctly tessellate; posterior surface with lateral carina on lower half, without oblique carina. Coxae usual shape, without tubercle. Fore trochanter narrow, longer than wide. Basitibial plate of hind leg carinate marginally. Inner hind tibial spur pectinate, with 3-4 teeth as in Fig. 20E $(n=4)$. Fore wing with three submarginal cells.

AbDomen. Disc of T1 without distinct PP and with weak lineolation over entire surface (Fig. 15F). Disc of T2 weakly lineolate on anterior and posterior area, and nearly smooth on medial area. Discs of T3-T4 with weak lineolation over entire surface.

\section{Male}

Measurements ( $\mathrm{n}=3$, unit $\mathrm{mm}) . \mathrm{BL}=4.77-5.38(4.90 \pm 0.36), \mathrm{WL}=3.77-4.46(4.21 \pm 0.31), \mathrm{HL}=1.42-$ $1.73(1.60 \pm 0.13), \mathrm{HW}=1.36-1.76(1.56 \pm 0.16), \quad \mathrm{IOD}=0.27-0.31 \quad(0.30 \pm 0.02), \quad \mathrm{OOD}=0.27-0.29$ $(0.27 \pm 0.01), \quad \mathrm{OCD}=0.16-0.22 \quad(0.19 \pm 0.03), \quad \mathrm{UOD}=0.89-1.13 \quad(1.00 \pm 0.10), \quad \mathrm{MOD}=0.93-1.24$ $(1.08 \pm 0.13), \quad \mathrm{LOD}=0.69-1.02 \quad(0.86 \pm 0.14), \quad \mathrm{IAD}=0.16-0.24 \quad(0.20 \pm 0.04), \quad \mathrm{AOD}=0.22-0.31$ $(0.25 \pm 0.04), \mathrm{CAL}=0.27-0.31(0.30 \pm 0.02), \mathrm{CPL}=0.29-0.38(0.34 \pm 0.04), \mathrm{EL}=1.00-1.24(1.13 \pm 0.10)$, $\mathrm{EW}=0.38-0.47(0.42 \pm 0.04), \mathrm{GW}=0.36-0.51(0.44 \pm 0.06), \mathrm{SPL}=0.36-0.42(0.46 \pm 0.04), \mathrm{F} 1 \mathrm{~L}=0.13-$ $0.16(0.14 \pm 0.01), \quad \mathrm{F} 2 \mathrm{~L}=0.16-0.20 \quad(0.18 \pm 0.02), \quad \mathrm{F} 3 \mathrm{~L}=0.16-0.18 \quad(0.17 \pm 0.01), \quad \mathrm{F} 2 \mathrm{~W}=0.13-0.16$ $(0.15 \pm 0.01), \quad \mathrm{MsW}=1.42-1.77 \quad(1.60 \pm 0.15), \quad \mathrm{SCL}=0.36-0.42 \quad(0.39 \pm 0.03), \quad \mathrm{MNL}=0.20-0.22$ $(0.21 \pm 0.01), \mathrm{MPL}=0.27-0.29(0.28 \pm 0.01), \mathrm{MtW}=1.29-1.61(1.46 \pm 0.13)$.

Coloration. Body black except for the following parts: lower half or margin dark yellow; mandible reddish brown; labrum dark yellow; pedicel and F1 yellowish brown ventrally; tegula yellowish brown translucent; tibial spur yellow; tarsi yellowish brown or brown; metasomal terga narrowly yellowish brown translucent apically. Wings transparent, veins and stigma blackish brown.

PubesCence. Body hairs whitish, and covered with erect and sparse straight or fine branched hairs except for the following parts: pronotal dorsum to lobe and metanotum sparsely tomentose. Disc of T1 with sparse short hairs. Discs of T2-T4 with moderately dense short hairs over entire surface. T2-T3 with thin apical fimbriae, not clear in female.

STRUCTURE AND SCULPTURE HEAD. Based on normal specimens (not cephalic polymorphism) Head nearly as long as wide; $\mathrm{HW}: \mathrm{HL}=1: 1.03$. Vertex rounded in frontal view. MOD:UOD:LOD=1:0.92:0.79. IOD:OOD:OCD $=1: 0.93: 0.65$. IAD:AOD $=1: 1.11$. Ocellocular area moderately densely puctate, IS smooth (IS =1-4 d). Paraocular area and frons weakly shiny, with shallow reticulate PP. Supraclypeal area slightly convex, weakly shiny, with moderately dense PP, IS weakly tessellate (IS $=1-2.5 \mathrm{~d}$ ). CPL:CAL $=1: 0.87$. Clypeus nearly flat, with moderately dense PP over entire sutface; IS smooth $(\mathrm{IS}=1-3 \mathrm{~d}) . \mathrm{EW}: \mathrm{GW}=1: 1.04$. Genal area on lower margin and postgena with straight ridges. Malar space linear. Hypostomal carinae nearly parallel. Mandible edentate. Antenna short, not reaching metasoma. F2L:F2W=1:0.83; flagellum nearly flattened ventrally.

THOARX. Dorsolateral angle of pronotum obtuse; lateral surface without ridges; lateral lobe rounded. Tegula ovoid, nearly smooth. Mesoscutum with dense PP over entire surface; IS weakly tessellate on anterior half, nearly smooth on posterior half (IS $=0.5-2 \mathrm{~d}$ ); parapsidal line a narrow groove. Mesoscutellum with sparser PP over entire surface; IS smooth (IS=1-4 d). Metanotum weakly rugulose. Mesepisternum with moderately dense shallow PP on upper area and weak reticulate PP on lower area; IS smooth. SCL:MNL:MPL=1:0.53:0.72. Propodeum: metapostnotum weakly shiny and gently inclined, with short straight ridges occupying anterior half and weakly tessellate on posterior half; junction between metapostnotum and posterior surface not carinate, weakly tessellate; lateral surface distinctly tessellate; posterior surface with lateral carina on lower half, without oblique carina. Coxae 
usual shape, without tubercle. Fore trochanter narrow, longer than wide. Basitibial plate of hind leg carinate marginally. Inner hind tibial spur serrate. Fore wing with three submarginal cells.

AвDOMEN. Disc of T1-T3 with fine sparse PP. Disc of T1 basally weakly lineolate or smooth (paratype and $1 \hat{\delta}$ lineolate, but 1 not lineolate). Disc of T2-T3 weakly lineolate on anterior and posterior areas, and nearly smooth on medial area. Discs of T4 with weak lineolation over entire surface. S7 with moderately long, apically rounded median process.

GenitALIA. Gonobase flat at bottom, ventral arms connected with each other at upper ends; gonocoxite smooth; ventral retrorse lobe tongue-like, moderately long but not reaching gonobase, with sparse short hairs ventrally.

\section{Distribution}

Japan (northern to central Ryukyus: Kuro-shima Is., Iwo-jima Is., Take-shima Is., Yaku-shima Is., Kuchinoerabu-jima Is., Nakano-shima Is., Suwanose-jima Is., Akuseki-jima Is., Takara-jima Is.).

\section{Flight period}

Female: April to October.

Male: August to October. The flight records of male are based on the collecting data of the original description (Ebmer et al. 1994).

\section{Flower records}

Ampelopsis glandulosa (Wall.) Momiy. var. hancei (Planch.) Momiy. (Vitaceae), Artemisia indica Willd. var. maximowiczii (Nakai) H.Hara (Asteraceae), Psychotria serpens L. (Rubiaceae), and Sambucus racemosa L. subsp. sieboldiana (Miq.) H.Hara. (Adoxaceae).

Lasioglossum (Hemihalictus) spectrum sp. nov. urn:lsid:zoobank.org:act:D53C2563-540A-47B6-BD17-4FDE9FF7BFAD

Figs 10, 16A-B, 17E, 19B, 20F

\section{Diagnosis}

Females are similar to $L$. (H.) epicinctus but are separated from them by the frons with sparse hairs (not mixed with tomentose hairs) and the ridges of the metapostnotum long (nearly reaching posterior margin as in Fig. 10F). In contrast, in L. (H.) epicinctus, the frons is mixed with dense whitish tomentose hairs and the ridges of the metapostnotum are short (only present on basal area).

\section{Etymology}

The specific name is derived from 'Obake', meaning 'ghost' in Japanese. This species has been called "Obake-chibi-kohanabachi" in Japanese, hence its scientific name.

\section{Material examined}

\section{Holotype}

JAPAN - Kyushu • + ; Fukuoka Pref., Soeda-machi, Kyushu Univ., Hikosan Exp. St.; 33²8'48.746" N, 13054'55.452" E; 18 Jul. 2014; R. Murao leg.; ELKU.

[Verbatim label: JAPAN: Kyushu/Kyushu Univ., Hikosan Exp. St./Soeda-machi/Fukuoka Pref./18. vii. 2014/Ryuki Murao leg. // N33²8'48.746" E13054'55.452" // HOLOTYPE // Lasiioglossum (Hemihalictus) spectrum Murao] 


\section{Paratypes}

JAPAN - Honshu • 10 đ̂̀ ; Iwate Pref., Morioka; 18 Jun. 1980; Y. Maeta leg., from nest; MNHAH •

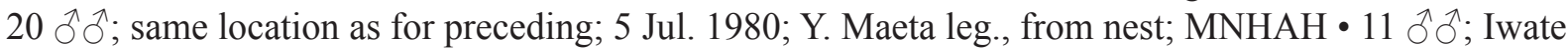
Pref., Morioka, Kuriyagawa; 21 Jul. 1980; Y. Maeta leg., from nest; MNHAH • 3 ठิ $\widehat{\jmath}$; same location as for preceding; 30 Jul. 1980; Y. Maeta leg., from nest; MNHAN • $2 \stackrel{\jmath}{\jmath}$; same location as for preceding;

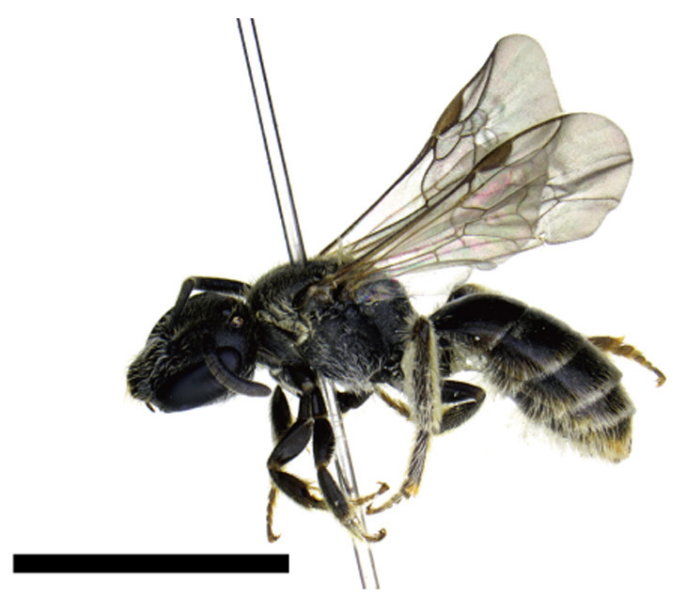

A
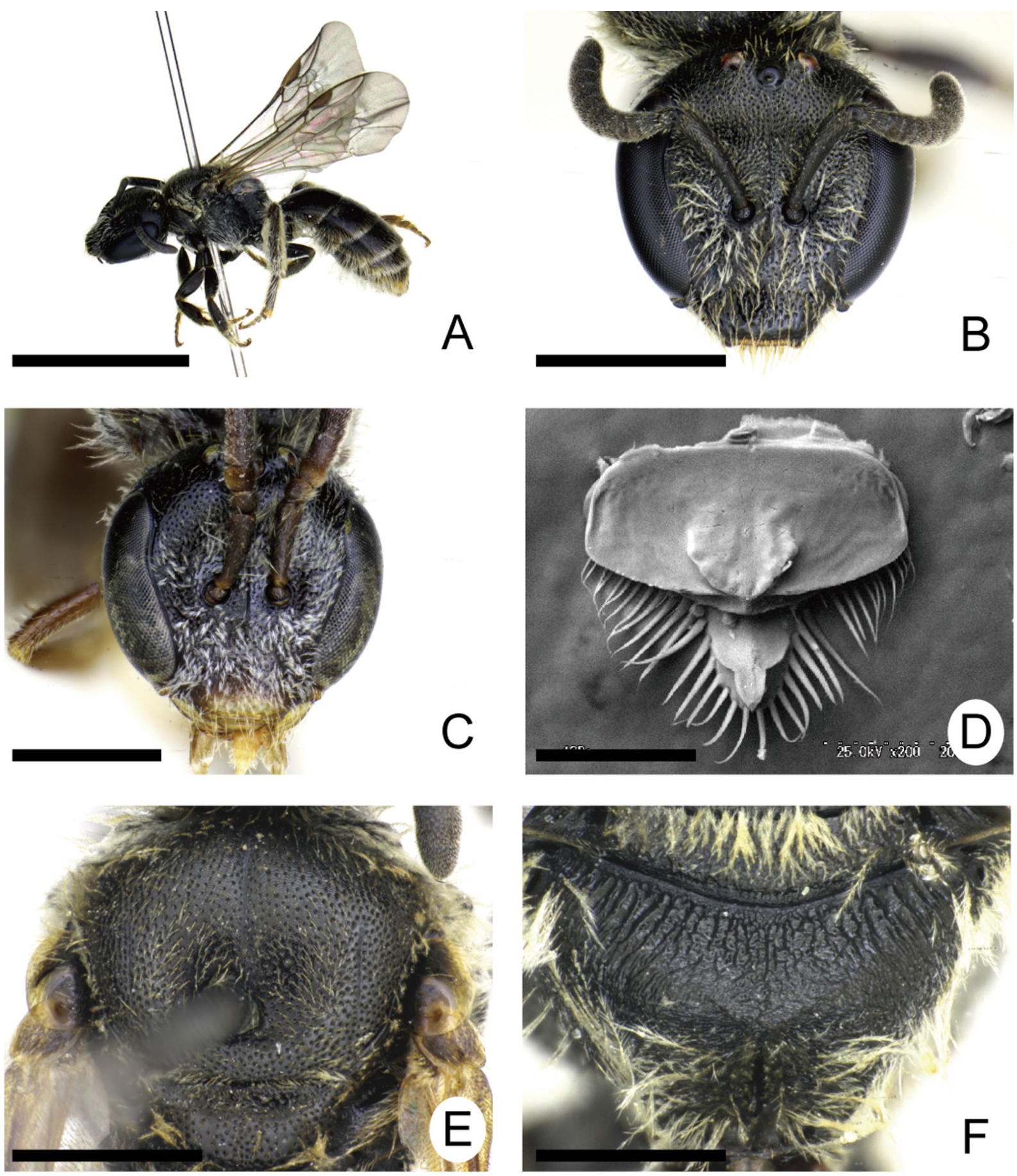

Fig. 10. Lasioglossum (Hemihalictus) spectrum sp. nov. A. $\odot$, lateral habitus. B. $q$, head in frontal view. C. $\hat{O}$, head in frontal view. D. $q$, labrum. E. + , mesoscutum. F. $\circ$, metapostnotum. Scale bars: $\mathrm{A}=$ $3 \mathrm{~mm} ; \mathrm{B}=1 \mathrm{~mm} ; \mathrm{C}, \mathrm{E}-\mathrm{F}=0.5 \mathrm{~mm} ; \mathrm{D}=0.2 \mathrm{~mm}$. 
1 Aug. 1980; Y. Maeta leg., from nest; MNHAH • 1 क; Shimane Pref., Okinoshima Is., Nagaobana, Chibu; $36^{\circ}$ N, $133^{\circ} 03^{\prime}$ E; 28 Aug. 2014; K. Otsui leg.; cMur • 1 q; Shimane Pref., Oda, Mt Sanbe; $35^{\circ} 9^{\prime}$ N, 132 $37^{\prime}$ E; 6 Aug. 2015; K. Otsui leg.; cMur. - Kyushu • 2 우; Fukuoka Pref., Soeda-machi, Kyushu Univ., Hikosan Exp. St.; 33²8'48.746" N, 13054'55.452" E; 13 Jun. 2014; R. Murao leg., ELKU • 1 क; same location as for preceding; 19 Sep. 2013; R. Murao leg.; ELKU • 2 q ; same location as for preceding; 23 May 2014; R. Murao leg.; ELKU • 2 우; same location as for preceding; 18 Jul. 2014; R. Murao leg.; ELKU • 2 ㅇ; Fukuoka Pref., Tagawa-gun, Soeda-machi, Mt Hiko-san; $33^{\circ} 28^{\prime} 48.766^{\prime \prime} \mathrm{N}, 130^{\circ} 54^{\prime} 55.452^{\prime \prime}$ E-3329'16.788" N, 13054'56.461" E; 17 Jul. 2014; R. Murao leg.; ELKU • 1 \%; Hikosan (Buzen); 8 Jul. 1939; K. Yasumatsu leg.; ELKU; 1 \%; same location as for preceding; 28 Jul. 1939; K. Yasumatsu leg.; ELKU • 1 क; Mt Hiko-san, Kajiya; 10 May 1973; K. Takeno leg.; ELKU • 1 क; same location as for preceding; 4 Jun. 1973; K. Takeno leg.; ELKU • 1 o ; Fukuoka Pref., Tagawa-gun, Nishi-Soeda; 18 Jun. 1968; K. Kanmiya leg.; ELKU • 1 q; Fukuoka, Mt Hiko; 4 May 1969; K. Kanmiya leg.; ELKU • 1 क ; same location as for preceding; 11 Jul. 1969; K. Kanmiya leg.; ELKU • 1 क; same location as for preceding; 8 Jul. 1970; K. Nozato leg.; ELKU • 1 क; same location as for preceding; 2 May 1971; H. Makihara leg.; ELKU • 1 \%; same location as for preceding; 7 Jul. 1971; M.T. Chujo leg.; ELKU • 2 9 9 ; same location as for preceding; 29 May 1972; K. Takeno leg.; ELKU • 1 q; same location as for preceding; 1 Jun. 1972; K. Takeno leg.; ELKU • 2 q $ᄋ$; same location as for preceding; 28 Apr. 1976; K. Takeno leg.; ELKU • 1 क; same location as for preceding; 22 May 1980; K. Takeno leg.; ELKU • 1 क; same location as for preceding; 14 Aug. 1980; K. Takeno leg.; ELKU • 1 क; same location as for preceding; 13 Jun. 1969; K. Takeno leg.; ELKU • 1 \%; same location as for preceding; 21 Jun. 1966; A. Taketani leg.; ELKU • 2 + $\%$; same location as for preceding; 22 Jun. 1966; A. Taketani leg.; ELKU • 1 q; same location as for preceding; 23 Jun. 1966; K. Takeno leg.; ELKU • 1 q; same location as for preceding; 25 Jun. 1966; A. Taketani leg.; ELKU • 1 क; same location as for preceding; 18 Jul. 1966; K. Takeno leg.; ELKU • 1 क; same location as for preceding; 23 Jul. 1966; K. Takeno leg.; ELKU • 1 क; same location as for preceding; 6 Aug. 1966; K. Takeno leg.; ELKU • 1 क ; same location as for preceding; 30 Aug. 1966; K. Takeno leg.; ELKU • 2 o ; ; same location as for preceding; 15 May 1967; S. Kimoto leg.; ELKU • 1 क ; same location as for preceding; 17 May 1967; K. Takeno leg.; ELKU • 1 क ; same location as for preceding; 25 May 1967; S. Kimoto leg.; ELKU • 1 q; same location as for preceding; 26 May 1967; S. Kimoto leg.; ELKU • 1 क; same location as for preceding; 3 Jun. 1967; K. Takeno leg.; ELKU • 1 \%; same location as for preceding; 4 Jul. 1967; K. Takeno leg.; ELKU • 1 q; same location as for preceding; 7 Jul. 1968; K. Kanmiya leg.; ELKU • 3 + $q$; same location as for preceding; 21 Jul. 1968; K. Kanmiya leg.; ELKU • 1 क; same location as for preceding; 11 May 1971; Y. Hirashima leg.; ELKU • 1 क; same location as for preceding; 7 Jul. 1971; Y. Hirashima leg.; ELKU • 1 क; Fukuoka Pref., Fukuoka-shi, Nishi-ku, Genkaijima; 3341'24.799" N, 130¹3'52.528" E; 19 Jul. 2009; R. Murao leg.; ELKU • 1 q; Fukuoka Pref.,

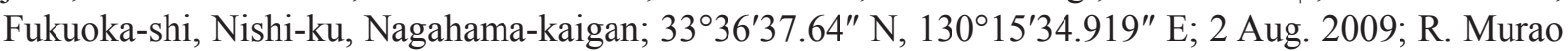
leg.; ELKU • 3 क 9 ; Fukuoka Pref., Ushikubi-dam, Ohnojyo-shi; 29 Jun. 2011; R. Murao leg.; ELKU • 1 क; Fukuoka Pref., Fukuoka-shi, Sawara-ku, Shiibaru; 3 May 2010; R. Murao leg.; ELKU • 2 우; Fukuoka Pref., Chikushino-shi, Kouzono, Ônejiyama-rindo; 4 Jul. 2009; R. Murao leg.; ELKU • 1 O; Fukuoka Pref., Fukuoka-shi, Higashi-ku, Shikanoshima; 14 Apr. 2013; R. Murao leg.; ELKU • 1 क; Saga Pref., Tosu-shi, Mt Kusenbu-yama; 3325'1.353" N, 130²6'46.819" E; 6 Jun. 2010; R. Murao leg.; ELKU • 1 q; same location as for preceding; 12 Jun. 2010; R. Murao leg.; ELKU • 3 우; same location as for preceding; 19 Sep. 2013; Y. Murao leg.; ELKU • 2 우; Oita Pref., Kusu-gun, Kokonoemachi, Chojyabaru; 337'6.773" N, 131 ${ }^{\circ} 13^{\prime} 49.331^{\prime \prime}$ E; 1050 m a.s.1.; 13 Aug. 2010; Y. Murao leg.; ELKU; 3 क $\odot$; same location as for preceding; 15 May 2011; R. Murao leg.; ELKU • 1 ; ; same location as for preceding; 12 Aug. 2011; R. Murao leg.; ELKU • 8 q $q$; Kumamoto Pref., Aso-gun, Minamiasomura, near Kusasenri; 30 Jul. 2009; R. Murao leg.; ELKU・ 1 q; Kumamoto Pref., Aso-shi, Aso-machi,

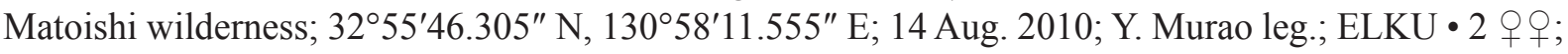
same location as for preceding; 5 Aug. 2013; Y. Murao leg.; ELKU • 1 q; Kumamoto Pref., Aso-gun, Minamiaso-mura, Asosannishi-eki; 30 Jul. 2009; R. Murao leg.; ELKU • 1 क; Kumamoto Pref., Aso- 
gun, Nishihara-mura, near Mt Tawara; 30 Jul. 2009; R. Murao leg.; ELKU. - Ryukyus • 1 q; Kagoshima Pref., Yaku-shima Is., Onoaida; 40-200 m a.s.l.; 27 May 1982; S. Ikudome leg.; KWC.

\section{Non-type material}

JAPAN - Hokkaido• 1 \%; Hamakoshimizu; 27 May 1966; MNHA • 1 o; same location as for preceding; 28 May 1966; MNHAH • 2 q ; same location as for preceding; 11 Jun. 1966; MNHAH • 1 q; same location as for preceding; $8 \mathrm{Jul}$. 1966; K. Yamauchi leg.; MNHAH $\bullet 1$ क ; same location as for preceding; 29 Sep. 1966; MNHAH $\bullet 2$ o $\%$; same location as for preceding; 20 Jun. 1967; MNHAH 2 o $q$; same location as for preceding; 9 Aug. 1967; MNHAH • 1 \%; Asahikawa, Inosawa; 10 Jun. 1969; MNHAH • 1 क; Yukomanbetsu; 9 Jul. 1968; MNHAH • 4 ㅇ; A Ahosoro; 12 Jun. 2010; O. Tadauchi leg.; ELKU •

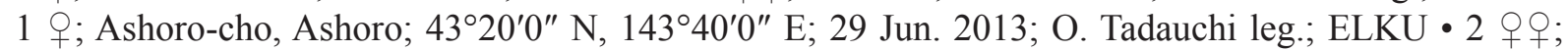
same location as for preceding; 2 Jul. 2013; O. Tadauchi leg.; ELKU • 1 क; Honbetsu-cho, Hobetsu; $43^{\circ} 10^{\prime} 0^{\prime \prime}$ N, 143³5'0" E; 1 Jul. 2013; O. Tadauchi leg.; ELKU. - Honshu • 1 क; Aomori Pref., Namioka, Mt Bonzyu; 29 May 1983; M. Yamada leg.; MNHAH • 1 q; same location as for preceding; 1 Aug. 1983; M. Yamada leg.; MNHAH • 2 + $O$; Miyagi Pref., Rifu-cho; 24 May 1980; K. Gôukon leg.; MNHAH • 2 ㅇ; ; Ibaraki Pref., Mt Gozen-yama; 30 Jul. 1976; M. Kitsukawa leg.; MNHAH • 1 क; Shizuoka Pref., Ito-shi, Mt Omuro; 4 May 2005; K. Gôukon leg.; cGou • 2 + + ; Kyoto Pref., Botanical Garden, Kyoto Univ.; 3 Jun. 1986; T. Inoue leg.; MNHAH • 4 우; Hyogo Pref., Kita-ku, Ikuno-Doujyo-cho; 4 May 2008; R. Murao leg.; ELKU • 1 क; Shimane Pref., Mt Sanbe; 5 May 1992; T. Yamaguchi leg.; SULE • 1 ; ; same location as for preceding; 22 May 1992; T. Yamaguchi leg.; SULE $\bullet 1$; ; same location as for preceding; 23 Aug. 1992; T. Yamaguchi leg.; SULE • 1 \%; Shimane Pref., Campus of Shimane Univ.; 16 Jul. 1993; Y. Okajima leg.; SULE. - Kyushu • 1 \&; Kumamoto Pref., Aso-gun, Choyo-son, Setaura; 30 Apr. 1986; M. Iwata leg.; AETU • 4 우; same location as for preceding; 8 May 1986; M. Iwata leg.; AETU • 1 ㅇ; same location as for preceding; 30 Jun. 1986; M. Iwata leg.; AETU • 1 ㅇ; same location as for preceding; 11 Jul. 1986; M. Iwata leg.; AETU • 1 q; same location as for preceding; 13 Sep. 1986; M. Iwata leg.; AETU • 2 우; same location as for preceding; 27 Apr. 1987; M. Iwata leg.; AETU • 1 \%; same location as for preceding; 8 Jul. 1987; M. Iwata leg.; AETU • 1 \%; same location as for preceding; 23 Jul. 1987; M. Iwata leg.; AETU • 1 क; same location as for preceding; 16 Nov. 1987; M. Iwata leg.; AETU • 3 우; same location as for preceding; 30 Apr. 1988; M. Iwata leg.; AETU • 2 우여 same location as for preceding; 23 May 1988; M. Iwata leg.; AETU • 3 우; same location as for preceding; 13 Jun. 1988; M. Iwata leg.; AETU • 3 9 ; same location as for preceding; 11 Jul. 1988; M. Iwata leg.; AETU • 1 क; same location as for preceding; 12 Aug. 1988; M. Iwata leg.; AETU • 6 o ; ; same location as for preceding; 17 Apr. 1989; M. Iwata leg.; AETU • 2 q 9 ; same location as for preceding; 27 Apr. 1989; M. Iwata leg.; AETU • 5 우; same location as for preceding; 8 May 1989; M. Iwata leg.; AETU • 1 q; same location as for preceding; 7 Jun. 1989; M. Iwata leg.; AETU • 8 q ; ; same location as for preceding; 19 Jun. 1989; M. Iwata leg.; AETU • 1 क; same location as for preceding; 29 Jun. 1989; M. Iwata leg.; AETU • 6 q ; same location as for preceding; 6 Jul. 1989; M. Iwata leg.; AETU • 2 ○ ; same location as for preceding; 14 Jul. 1989; M. Iwata leg.; AETU • 1 क ; same location as for preceding; 19 Jul. 1989; M. Iwata leg.; AETU • 1 q; same location as for preceding; 6 Aug. 1989; M. Iwata leg.; AETU • 1 \%; same location as for preceding; 25 Sep. 1989; M. Iwata leg.; AETU • 1 \%; same location as for preceding; 6 Oct. 1989; M. Iwata leg.; AETU • 1 क; Kumamoto Pref., Aso-gun, Nishihara-mura; 22 Apr. 2000; M. Murase leg.; AETU • 2 + 0 ; same location as for preceding; 29 May 2000; R. Murao leg.; AETU • 2 q ; same location as for preceding; 12 May 2000; R. Murao and M. Murase leg.; AETU • 2 우영 same location as for preceding; 20 May 2000; R. Murao and M. Murase leg.; AETU • 2 q $\odot$; same location as for preceding; 29 May 2000; M. Murase leg.; AETU • 2 + $q$; same location as for preceding; 6 Jul. 2000; R. Murao and M. Murase leg.; AETU • 2 q ; same location as for preceding; 14 Jun. 2000; R. Murao leg.; AETU • 13 q 9 ; same location as for preceding; 26 Jun. 2000; R. Murao and M. Murase leg.; AETU • 2 + 9 ; same location as for preceding; 17 Jul. 2000; R. Murao leg.; AETU • 2 우; same location as for preceding; 8 Sep. 2000; M. Murase leg.; AETU • 14 우우 Kumamoto Pref., Kikuchi-gun, Kikuyo-machi; 22 Apr. 2000; R. Murao and M. Murase leg.; AETU • 4 q ; same location 
as for preceding; 29 Apr. 2000; R. Murao and M. Murase leg.; AETU • 13 $q$; same location as for preceding; 12 May 2000; R. Murao and M. Murase leg.; AETU • 23 우; same location as for preceding; 20 May 2000; R. Murao and M. Murase leg.; AETU • 26 우; same location as for preceding; 29 May 2000; R. Murao and M. Murase leg.; AETU • 19 q $ᄋ$; same location as for preceding; 6 Jun. 2000; R. Murao and M. Murase leg.; AETU • 24 + 9 ; same location as for preceding; 14 Jun. 2000; R. Murao and M. Murase leg.; AETU • 26 qक; same location as for preceding; 26 Jun. 2000; R. Murao and M. Murase leg.; AETU • 17 + 9 ; same location as for preceding; 6 Jul. 2000; R. Murao and M. Murase leg.; AETU • 13 q ; ; same location as for preceding; 17 Jul. 2000; R. Murao and M. Murase leg.; AETU • 10 우; same location as for preceding; 26 Jul. 2000; R. Murao and M. Murase leg.; AETU • 9 ㅇ; ; same location as for preceding; 4 Aug. 2000; R. Murao and M. Murase leg.; AETU • 15 우; same location as for preceding; 16 Aug. 2000; R. Murao and M. Murase leg.; AETU • 3 q $q$; same location as for preceding; 28 Aug. 2000; R. Murao and M. Murase leg.; AETU $\bullet 7$ $q$; ; same location as for preceding; 8 Sep. 2000; R. Murao and M. Murase leg.; AETU • 6 + $q$; same location as for preceding; 19. Sep. 2000; R. Murao and M. Murase leg.; AETU -5 qo ; same location as for preceding; 1 Oct. 2000; R. Murao and M. Murase leg.; AETU • 11 q ; ; same location as for preceding; 10 Oct. 2000; R. Murao and M. Murase leg.; AETU • 3 क 9 ; same location as for preceding; 19 Oct. 2000; R. Murao and M. Murase leg.; AETU • 3 우; same location as for preceding; 27 Oct. 2000; M. Murase leg.; AETU • 6 우; same location as for preceding; 6 Nov. 2000; R. Murao and M. Murase leg.; AETU • 3 우; Nagasaki Pref., Tsushima Is., Izuhara, Yora-Naiin; 13 May 2010; O. Tadauchi leg.; ELKU • 1 ; ; Nagasaki Pref., Tsushima Os., Izuhara, Konoda-Aren; 14 May 2010; O. Tadauchi leg.; ELKU.

\section{Description}

\section{Female}

Measurements $(\mathrm{n}=5$, unit $\mathrm{mm}) . \mathrm{BL}=4.75-5.00(4.88 \pm 0.13), \mathrm{WL}=3.88-4.50(4.25 \pm 0.25), \mathrm{HL}=1.42-$ $1.48(1.45 \pm 0.03), \mathrm{HW}=1.35-1.45(1.41 \pm 0.04), \mathrm{IOD}=0.26(0.26 \pm 0.00), \mathrm{OOD}=0.26-0.27(0.26 \pm 0.01)$, $\mathrm{OCD}=0.16(0.16 \pm 0.00), \mathrm{UOD}=0.87-0.94(0.90 \pm 0.02), \mathrm{MOD}=1.03-1.06(1.04 \pm 0.03), \mathrm{LOD}=0.68-$ $0.77(0.74 \pm 0.04), \mathrm{IAD}=0.13-0.15(0.14 \pm 0.01), \mathrm{AOD}=0.21-0.27 \quad(0.25 \pm 0.02), \mathrm{CAL}=0.24-0.27$ $(0.26 \pm 0.01), \mathrm{CPL}=0.27-0.32(0.29 \pm 0.02), \mathrm{EL}=1.55-1.70(1.62 \pm 0.06), \mathrm{EW}=0.35-0.42(0.39 \pm 0.03)$, $\mathrm{GW}=0.23-0.32(0.27 \pm 0.04), \quad \mathrm{SPL}=0.55-0.60 \quad(0.57 \pm 0.02), \quad \mathrm{F} 1 \mathrm{~L}=0.08 \quad(0.08 \pm 0.00), \quad \mathrm{F} 2 \mathrm{~L}=0.08$ $(0.08 \pm 0.00), \mathrm{F} 3 \mathrm{~L}=0.08(0.08 \pm 0.00), \mathrm{F} 2 \mathrm{~W}=0.11-0.13(0.12 \pm 0.01), \mathrm{MsW}=1.55-1.80(1.67 \pm 0.10)$, $\mathrm{SCL}=0.35-0.38(0.37 \pm 0.01), \mathrm{MNL}=0.18-0.23(0.20 \pm 0.02), \mathrm{MPL}=0.28(0.28 \pm 0.00), \mathrm{MtW}=1.65-$ $1.85(1.74 \pm 0.08)$.

Coloration. Body black except for the following parts: mandible reddish brown apically; F4-F10 brown (holotype) or yellowish brown ventrally; tegula yellowish brown translucent; tibial spur yellow; metasomal terga broadly yellowish brown translucent apically. Wings transparent, veins and stigma brown.

PuBESCENCE. Body hairs whitish, and covered with erect and sparse straight or fine branched hairs except for the following parts: pronotal dorsum to lobe and metanotum moderately densely tomentose; hind trochanter, femur, and tibia mixed with plumose hairs, forming scopa. Disc of T1 with sparse short hairs on medial area. Discs of T2-T4 with moderately dense short hairs over entire surface.

Structure And SCUlPtURe HeAD. Nearly as long as wide; HW:HL $=1: 1.03$. Vertex rounded in frontal view. MOD:UOD:LOD=1:0.87:0.71. IOD:OOD:OCD $=1: 1.03: 0.63$. IAD:AOD $=1: 1.83$. Ocellocular area densely puctate, IS nearly smooth (IS $=0.5-2 \mathrm{~d}$ ). Paraocular area and frons weakly shiny, with shallow reticulate PP. Supraclypeal area slightly convex, weakly shiny, with dense PP; IS weakly tessellate (IS=0.5-2 d). CPL:CAL=1:0.89. Clypeus nearly flat, with reticulate PP on upper half and larger shallow PP on lower half; IS nearly smooth over entire surface (IS $=0.5-1 \mathrm{~d}$ on lower area). $E W: G W=1: 0.70$. Genal area to postgena with weak straight ridges. Malar space linear. Occiput not 
carinate. Hypostomal carinae nearly parallel. Mandible bidentate. Labrum (Fig. 10D): basal area approximately $1.9 \times$ as wide as long; distal process approximately $0.6 \times$ as long as basal area, tonguelike, and without lateral projection; distal keel pointed apically. Antenna short, not reaching metasoma. F2L:F2W=1:1.44; flagellum nearly flattened ventrally.

Thorax. Dorsolateral angle of pronotum obtuse; lateral surface without ridges; lateral lobe rounded. Tegula ovoid, nearly smooth. Mesoscutum (Fig. 10E) with dense PP over entire surface; IS distinctly tessellate on anterior half, and weakly tessellate on posterior half (but nearly smooth on posterior margin) (IS $=0.5-2 \mathrm{~d}$ ); parapsidal line a narrow groove. Mesoscutellum with moderately dense PP over entire surface; IS nearly smooth (holotype and some paratypes) or weakly tessellate (two paratypes) over entire surface (IS $=0.5-3 \mathrm{~d}$ ). Metanotum weakly rugulose. Mesepisternum reticulate-punctate over entire surface. SCL:MNL:MPL=1:0.55:0.75. Propodeum: metapostnotum (Fig. 10F) dimly shiny and gently inclined, with straight ridges occupying anterior $2 / 3$ (holotype and some paratypes) or on anterior half, with coarse tessellation on posterior $1 / 3$ or half; junction between metapostnotum and posterior surface not carinate, coarsely tessellate; lateral surface weakly rugulae and coarsely tessellate; posterior surface with lateral carina on lower half, without oblique carina. Coxae normal shape, without tubercle. Fore trochanter narrow, longer than wide. Basitibial plate of hind leg carinate marginally. Inner hind tibial spur pectinate, with $2-3$ teeth as in Fig. $20 \mathrm{~F}(\mathrm{n}=10)$. Fore wing with three submarginal cells.

AвDOMEN. Disc of T1 with weak lineolation on basal and apical areas (not overlapping in puncture zone on medial area) (Fig. 16A), and with sparse fine PP on medial area. Disc of T2 with weak lineolation on basal and apical area, and without lineolation on medial area. T3-T4 weakly lineolate over entire surface.

\section{Male}

MeAsurements $(\mathrm{n}=5$, unit $\mathrm{mm}) . \mathrm{BL}=3.62-4.54(4.32 \pm 0.43), \mathrm{WL}=3.08-3.77(3.58 \pm 0.27), \mathrm{HL}=1.20$ $1.38(1.32 \pm 0.07), \mathrm{HW}=1.20-1.40 \quad(1.32 \pm 0.07), \mathrm{IOD}=0.20-0.24 \quad(0.23 \pm 0.02), \quad \mathrm{OOD}=0.24-0.29$ $(0.27 \pm 0.01), \quad \mathrm{OCD}=0.16-0.20 \quad(0.17 \pm 0.02), \quad \mathrm{UOD}=0.82-0.91 \quad(0.88 \pm 0.03), \quad \mathrm{MOD}=0.84-0.98$ $(0.93 \pm 0.05), \quad \mathrm{LOD}=0.58-0.67 \quad(0.63 \pm 0.04), \quad \mathrm{IAD}=0.13-0.20 \quad(0.16 \pm 0.02), \quad \mathrm{AOD}=0.18-0.22$ $(0.21 \pm 0.02), \mathrm{CAL}=0.20-0.27(0.23 \pm 0.02), \mathrm{CPL}=0.27-0.33(0.30 \pm 0.02), \mathrm{EL}=0.87-0.98(0.95 \pm 0.04)$, $\mathrm{EW}=0.38-0.44(0.42 \pm 0.02), \mathrm{GW}=0.24-0.33(0.28 \pm 0.03), \mathrm{SPL}=0.36-0.42(0.39 \pm 0.02), \mathrm{F} 1 \mathrm{~L}=0.09-$ $0.13(0.11 \pm 0.01), \quad \mathrm{F} 2 \mathrm{~L}=0.13-0.16 \quad(0.15 \pm 0.01), \quad \mathrm{F} 3 \mathrm{~L}=0.13-0.16 \quad(0.15 \pm 0.01), \quad \mathrm{F} 2 \mathrm{~W}=0.11-0.13$ $(0.12 \pm 0.01), \mathrm{MsW}=1.16-1.32(1.26 \pm 0.06), \mathrm{SCL}=0.29-0.33(0.32 \pm 0.02), \mathrm{MNL}=0.16(0.16 \pm 0.00)$, $\mathrm{MPL}=0.20-0.22(0.21 \pm 0.01), \mathrm{MtW}=1.03-1.26(1.17 \pm 0.08)$.

Coloration. Body black except for the following parts: lower half of clypeus yellow; mandible yellow except for apically reddish; labrum yellow; F1 yellowish brown or brown ventrally; pronotal lobe yellowish brown; tegula yellow translucent; tibiae basally and apically yellow; tibial spur yellow; tarsi yellow; metasomal terga broadly yellowish brown translucent apically. Wings transparent, veins and stigma pale brown.

PubesCENCE. Body hairs whitish, and covered with erect and sparse straight or fine branched hairs except for the following parts: paraocular area, pronotal dorsum to lobe thinly tomentose. Metasomal terga with sparse, simple and short hairs over entire surface.

Structure and sculpture head. Nearly as long as wide; $\mathrm{HW}: \mathrm{HL}=1: 1.00$. Vertex rounded in frontal view. MOD:UOD:LOD=1:0.94:0.68. IOD:OOD:OCD =1:0.94:0.68. IAD:AOD=1:1.43. Ocellocular area with dense PP, IS nearly smooth (IS $=0.5-2 \mathrm{~d}$ ). Paraocular area and frons weakly shiny, with shallow reticulate PP. Supraclypeal area and clepeus nearly flat, weakly shiny, with moderately dense PP; IS smooth (IS=0.5-4 d). CPL:CAL=1:0.76. EW: GW=1:0.67. Genal area with weak straight ridges. Malar space linear. Occiput not carinate. Hypostomal carinae nearly parallel. Postgena longitudinal 
lineolate. Mandible edentate. Antenna short, not reaching metasoma. F2L:F2W=1:0.76; flagellum nearly flattened ventrally.

THORAX. Dorsolateral angle of pronotum obtuse; lateral surface without ridges; lateral lobe rounded. Tegula ovoid, nearly smooth. Mesoscutum with dense PP over entire surface; IS smooth except for anteriorly weakly tessellate (IS $=0.5-2 \mathrm{~d}$ ); parapsidal line a narrow groove. Mesoscutellum with moderately dense PP over entire surface; IS smooth (IS $=0.5-4 \mathrm{~d}$ ). Metanotum weakly rugulose. Mesepisternum with dense PP over entire surface; IS smooth (IS = 0.5-1 d). SCL:MNL:MPL=1:0.49:0.68. Propodeum: metapostnotum shiny and gently inclined, with short straight ridges occupying anterior half or anterior $2 / 3$, weakly tessellate or nearly smooth on posterior half or posterior $1 / 3$; junction between metapostnotum and posterior surface not carinate, weakly tessellate or nearly smooth; lateral surface weakly rugulose and distinctly tessellated; posterior surface with lateral carina on lower half, without oblique carina. Coxae normal shape, without tubercle. Fore trochanter narrow, longer than wide. Basitibial plate of hind leg weakly carinate marginally. Inner hind tibial spur serrate. Fore wing with three submarginal cells.

AbDomen. Disc of T1 without distinct PP and tessellation. Disc of T2-T4 with moderately dense fine PP, T2 without lineolation, T3-T4 with weak lineolation on apical margin. S7 with moderately long, apically rounded median process.

Genitalia. Gonobase flat at bottom; gonocoxite smooth; ventral retrorse lobe tongue-like, moderately long but not reaching gonobase, with sparse short hairs ventrally.

\section{Variation}

Disc of T1 lineolate only on basal area (Fig. 16B) in the specimens (not type series) collected from Hokkaido (northern Japan).

\section{Distribution}

Japan (Hokkaido, Honshu, Shikoku, Kyushu, Izu-shotô Islands, Tsu-shima Is., northern Ryukyus). Records of Lasioglossum (Hemihalictus) pallilomum (Strand, 1914) from the nearby continent, such as the Korean Peninsula, Russian Far East, and China (Ebmer 1978a, 1996, 2006), may correspond to this new species.

\section{Flight period}

Female: April to Novemver.

Males are collected from June to August based on 46 male specimens in the late Dr Sakagami's collection (MNHAH). These specimens were collected from the nest of this species (identified as L. (H.) pallilomum (Strand, 1914)).

\section{Flower records}

The specimens examined in this paper were collected on the flowers of 61 species in 30 families as follows. Acanthaceae: Justicia hayatae Yamam. Amaranthaceae: Achyranthes bidentata Blume var. japonica Miq. Apiaceae: Coelopleurum gmelinii (DC.) Ledeb. Asparagaceae: Barnardia japonica (Thunb.) Schult. \& Schult.f. Asteraceae: Achillea alpina L. subsp. japonica (Heimerl) Kitam.; Aster iinumae Kitam.; Crepidiastrum denticulatum (Houtt.) J.H.Pak \& Kawano; Erigeron annuus (L.) Pers.; Erigeron sumatrensis Retz.; Ixeridium dentatum (Thunb.) Tzvelev subsp. dentatum; Ixeris stolonifera A.Gray; Lactuca indica L.; Picris hieracioides L. subsp. japonica (Thunb.) Krylov; Youngia japonica (L.) DC. Brassicaceae: Brassica rapa L. var. oleifera DC.; Rorippa indica (L.) Hiern. Campanulaceae: Lobelia chinensis Lour.; Triodanis perfoliata (L.) Nieuwl. Caprifoliaceae: Lonicera japonica Thunb. 
MURAO R., Redifition and revision of the Lasioglossum sexstrigatus group in Japan

Commelinaceae: Commelina communis L. Convolvulaceae: Ipomoea lacunosa L. Cucurbitaceae: Cucurbita sp. Elaeagnaceae: Elaeagnus umbellata Thunb. var. umbellate. Elatinaceae: Stellaria sp. Fabaceae: Astragalus sinicus L.; Pueraria lobata (Willd.) Ohwi; Trifolium dubium Sibth. Gentianaceae: Gentiana zollingeri Fawc. Geraniaceae: Geranium carolinianum L. Lamiaceae: Clinopodium gracile (Benth.) Kuntze; Isodon inflexus (Thunb.) Kudô; Lamium amplexicaule L.; Prunella vulgaris L. subsp. asiatica (Nakai) H.Hara. Mazaceae: Mazus pumilus (Burm.f.) Steenis. Oleaceae: Ligustrum japonicum Thunb. Oxalidaceae: Oxalis corniculata L.; Oxalis debilis Kunth subsp. corymbosa (DC.) Lourteig. Plantaginaceae: Veronica persica Poir. Polygonaceae: Fallopia japonica (Houtt.) Ronse Decr. var. japonica; Persicaria longiseta (Bruijn) Kitag. Portulaceae: Portulaca oleracea L. Primulaceae: Lysimachia clethroides Duby. Ranunculaceae: Ranunculus japonicus Thunb.; Ranunculus silerifolius H.Lév. var. glaber (H.Boissieu) Tamura. Rosaceae: Malus pumila Mill.; Potentilla anemonifolia Lehm.; Potentilla fragarioides L. var. major Maxim.; Potentilla hebiichigo Yonek. \& H.Ohashi; Rosa luciae Rochebr. et Franch. ex Crèp.; Rosa onoei Makino var. hakonensis (Franch. \& Sav.) H.Ohba; Rosa rugosa Thunb.; Rubus buergeri Miq.; Rubus hirsutus Thunb.; Rubus palmatus Thunb. var. palmatus; Rubus parvifolius L. Rubiaceae: Paederia foetida L. Rutaceae: Zanthoxylum schinifolium Siebold \& Zucc. Solanaceae: Lycium chinense Mill.; Solanum nigrum L. Vitaceae: Ampelopsis glandulosa (Wall.) Momiy. var. heterophylla (Thunb.) Momiy.; Vitis ficifolia Bunge.

\section{Habitat}

This species has been collected from various environments such as cultivated or urban areas in the lowlands, seaside, mountain areas, and semi-natural grassland. The type locality is shown in Fig. 19B.

\section{Comments}

In Japan, this species has been identified as L. (H.) pallilomum (Strand, 1914), which might be endemic to Taiwan.

Lasioglossum (Hemihalictus) speculinum (Cockerell, 1925)

Figs 11, 16C, 17F, 20G

Halictus perplexans var.speculinus Cockerell, 1925:11(holotype: USNM,, , typelocality = Preobrageniya Bay, Siberia, Russia, examined).

Lasioglossum (Evylaeus) speculinum - Ebmer 1978a: 212; 1996: 294; 2006: 573.

Evylaeus (Prosopalictus) speculinus - Pesenko 2007b: 111.

Lasioglossum (Hemihalictus) speculinum - Murao 2017a: 461.

\section{Diagnosis}

Females are separated from other members of the sexstrigatus group occurring in Japan by a combination of the following character states: head relatively longer than wide (length/width ratio 1.07); metasoma entirely black; metasomal terga with white fimbriae on latero-apical margins; and disc of T1 basally to medially with distinct lineolation (Fig. 16C) (Murao 2017a).

\section{Material examined}

\section{Holotype}

RUSSIA - Siberia • + ; Preobrageniya Bay; 12 Jul.; USNM.

\section{Other material}

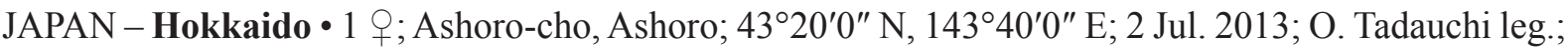

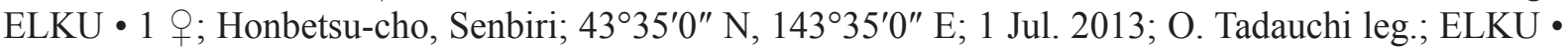
1 q; Ikeda (Tokachi); 14-16 Jul. 1953; Y. Hirashima leg.; ELKU • 2 q $ᄋ$; Sapporo, Barato; 21 Jun. 1973; 
M. Matsumoto leg.; MNHAH • 2 우; same location as for preceding; 28 Jun. 1973; M. Matsumoto leg.; MNHAH • 1 O; same location as for preceding; 22 Jul. 1973; M. Matsumoto leg.; MNHAH • 1 \&; same location as for preceding; 3 Aug. 1973; M. Matsumoto leg.; MNHAH • 2 우; Hamakoshimizu; 19 Jun. 1966; H. Fukuda leg.; MNHAH • 7 9 \% ; same location as for preceding; 26 Jul. 1966; H. Fukuda leg.; MNHAH • 1 q; same location as for preceding; 27 Jul. 1966; H. Fukuda leg.; MNHAH • 7 q $O$; same location as for preceding; 27 Sep. 1966; H. Fukuda leg.; MNHAH $\bullet 6$ + $\odot$; same location as for preceding; 28 Sep. 1966; H. Fukuda leg.; MNHAH • 2 qo; same location as for preceding; 19 Jun. 1967; H. Fukuda leg.; MNHAH • 4 9 \% ; same location as for preceding; 6 Jul. 1967; H. Fukuda leg.; MNHAH • 1 \%; Asahikawa, Inosawa; 25 Jun. 1969; MNHAH • 12 + + ; same location as for preceding; 27 Jun. 1969; MNHAH • 8 우; same location as for preceding; 13 Jul. 1969; MNHAH 2 o $\circ$; same location as for preceding; 26 Aug. 1969; MNHAH • 1 क ; same location as for preceding; 10 Jun. 1970; MNHAH • 2 Q 9 ; same location as for preceding; $25 \mathrm{Jul}$. 1970; MNHAH • 1 \%; same location as for preceding; 11 Aug. 1970 MNHAH • 3 + ; Sapporo; 16 Jul. 1968; S.F. Sakagami leg.; MNHAH • 3 q ; same location as for preceding; 23 Jul. 1968; S.F. Sakagami leg.; MNHAH • 1 O; same location as for preceding; 3 Aug. 1968; S.F. Sakagami leg.; MNHAH • 1 क; Tobetsu; 9 Jul. 1974; M. Ishikawa leg.; MNHAH • 1 क; Sapporo, Hokkaido University Campus; 6 Jun. 1959; S.F. Sakagami leg.; MNHAH • 1 + ; same location as for preceding; 11 Jun. 1959; S.F. Sakagami leg.; MNHAH • 1 क; same location as for preceding; 26 Jun. 1959 S.F. Sakagami leg.; MNHAH • 3 우; same location as for preceding; 30 Jun. 1959; S.F. Sakagami leg.; MNHAH • 1 क; same location as for preceding; 5 Jul. 1959; S.F. Sakagami leg.; MNHAH • 1 o; same location as for preceding; 6 Jul. 1959; S.F. Sakagami leg.; MNHAH • 3 q $ᄋ$; same location as for preceding; 14 Jul. 1959; S.F. Sakagami leg.; MNHAH • 2 $ᄋ$; same location as for preceding; 2 Sep. 1959; S.F. Sakagami leg.; MNHAH • 4 q ; ; same location as for preceding; 9 Sep. 1959; S.F. Sakagami leg.; MNHAH. - Honshu • 1 q; Aomori Pref., Misawa, Amagamori; 21 Jul. 1986; M. Yamada leg.; MNHAH • 1 क; Ibaraki Pref., Tsukuba, Kouyadai; 24 Jul. 1989; T. Matsumura leg.; MNHAH • 2 o $q$; Tottori Pref., Seihaku-gun, Daisen-cho; 16 Jul. 2004; T. Sugimoto leg.; cMur • 1 क; Okayama Pref., Soujya-shi; 5 Jul. 2006; Y. Kenmotsu leg.; ELKU • 1 q; Hiroshima Pref., Asida river; 17 May 1997; S. Nakamura leg.; ELKU. - Izu Islands • 2 qo+; Hachijo Is., Okago-Sokoto; 27 May 1964; Y. Hirashima and M. Shiga leg.; ELKU • 2 o+ ; same location as for preceding; 5 Jun. 1964; Y. Hirashima and M. Shiga leg.; ELKU. - Kyushu • 3 o ; ; Kumamoto Pref., Aso-gun, Aso-machi, near Mt Komezuka; 23 Jul. 2004; R. Murao and T. Sugimoto leg.; cMur • 1 + , Kumamoto Pref., Kikuchigun, Ohzu; 2 Jul. 2003; M. Ishida leg.; AETU • 1 q; same location as for preceding; 14 Jul. 2003; M. Ishida leg.; AETU • 2 우; Kumamoto Pref., Aso-gun, Ichinomiya-machi, Tateyamabokuya; 22 Jul. 2004; R. Murao leg.; cMur • 1 क; Kumamoto Pref., Aso-gun, Aso-machi, Yamadaseibubokuya; 22 Jul. 2004; T. Sugimoto leg.; cMur.

\section{Redescription}

\section{Female}

Measurements $(\mathrm{n}=5$, unit $\mathrm{mm}) . \mathrm{BL}=4.50-5.00(4.85 \pm 0.21), \mathrm{WL}=4.38-4.63(4.50 \pm 0.13), \mathrm{HL}=1.48-$ $1.61(1.55 \pm 0.05), \quad \mathrm{HW}=1.39-1.48 \quad(1.45 \pm 0.04), \quad \mathrm{IOD}=0.26-0.31 \quad(0.28 \pm 0.02), \quad \mathrm{OOD}=0.26-0.29$ $(0.28 \pm 0.01), \quad \mathrm{OCD}=0.16-0.19 \quad(0.18 \pm 0.01), \quad \mathrm{UOD}=0.90-1.00 \quad(0.96 \pm 0.04), \quad \mathrm{MOD}=1.06-1.13$ $(1.08 \pm 0.03), \quad \mathrm{LOD}=0.74-0.84 \quad(0.80 \pm 0.04), \quad \mathrm{IAD}=0.11-0.15 \quad(0.13 \pm 0.01), \quad \mathrm{AOD}=0.27-0.29$ $(0.28 \pm 0.01), \mathrm{CAL}=0.27-0.31(0.30 \pm 0.02), \mathrm{CPL}=0.27-0.34(0.32 \pm 0.03), \mathrm{EL}=1.65-1.75(1.70 \pm 0.05)$, $\mathrm{EW}=0.35-0.39(0.37 \pm 0.02), \mathrm{GW}=0.23-0.35(0.31 \pm 0.05), \mathrm{SPL}=0.56-0.61(0.59 \pm 0.03), \mathrm{F} 1 \mathrm{~L}=0.08-$ $0.11(0.09 \pm 0.01), \mathrm{F} 2 \mathrm{~L}=0.08-0.29(0.08 \pm 0.00), \mathrm{F} 3 \mathrm{~L}=0.08(0.08 \pm 0.00), \mathrm{F} 2 \mathrm{~W}=0.11-0.15(0.13 \pm 0.01)$, $\mathrm{MsW}=1.70-1.85 \quad(1.75 \pm 0.06), \quad \mathrm{SCL}=0.35-0.43 \quad(0.38 \pm 0.03), \quad \mathrm{MNL}=0.15-0.20 \quad(0.19 \pm 0.02)$, $\mathrm{MPL}=0.20-0.28(0.25 \pm 0.03), \mathrm{MtW}=1.70-2.00(1.83 \pm 0.11)$.

Coloration. Body black except for the following parts: mandible reddish brown apically; F8-F10 or F6-F10 yellowish brown ventrally; tegula yellowish brown translucent; tibial spur yellow; metasomal terga broadly yellowish brown translucent apically. Wings transparent, veins and stigma blackish brown. 
Pubescence. Body hairs whitish, and covered with erect and sparse straight or fine branched hairs except for the following parts: pronotal dorsum to lobe and metanotum densely tomentose; hind trochanter, femur, and tibia mixed with plumose hairs, forming scopa. Disc of T1 with sparse short hairs on medial and posterior areas. Discs of T2-T4 with moderately dense short hairs over entire surface.

Structure AND SCUlPtURE HEAD. Slightly longer than wide; $\mathrm{HW}: \mathrm{HL}=1: 1.07$. Vertex rounded in frontal view. MOD:UOD:LOD=1:0.89:0.74. IOD:OOD:OCD $=1: 1: 0.66$. IAD:AOD=1:2.18. Ocellocular area densely puctate, IS smooth (IS $=0.5-1.5 \mathrm{~d}$ ). Paraocular area and frons weakly shiny, with shallow reticulate PP. Supraclypeal area slightly convex, weakly shiny, with moderately dense PP, IS nearly smooth (IS $=0.5-4 \mathrm{~d}$ ). CPL:CAL=1:0.94. Clypeus nearly flat, with dense PP on upper half and larger shallow PP on lower half; IS smooth over entire surface (IS $=0.5-1 \mathrm{~d}$ on upper half). EW:GW=1:0.84. Genal area to postgena with straight ridges. Malar space linear. Occiput not carinate. Hypostomal carinae nearly parallel. Mandible bidentate. Labrum (Fig. 11C): basal area approximately $1.8 \times$ as wide as long; distal process approximately $0.6 \times$ as long as basal area, tongue-like, and without lateral projection; distal keel pointed apically. Antenna short, not reaching metasoma. F2L:F2W=1:1.56; flagellum nearly flattened ventrally.

THorax. Dorsolateral angle of pronotum obtuse; lateral surface without ridges; lateral lobe rounded. Tegula ovoid, nearly smooth. Mesoscutum (Fig. 11D) with dense PP over entire surface; IS weakly tessellate on anterior half, and nearly smooth on posterior half $(\mathrm{IS}=0.5-3 \mathrm{~d})$; parapsidal line a narrow groove. Mesoscutellum with sparse PP on submedian area and denser PP on marginal area; IS smooth over entire surface (IS $=1-4 \mathrm{~d}$ on submedian area, and $0.5-1.5 \mathrm{~d}$ on marginal area). Metanotum weakly rugulose. Mesepisternum with reticulate PP over entire surface. SCL:MNL:MPL=1:0.49:0.64. Propodeum: metapostnotum (Fig. 11E) weakly shiny and gently inclined, with nearly straight ridges reaching posterior area; junction between metapostnotum and posterior surface not carinate, weakly tessellate; lateral surface weakly rugulose; posterior surface with lateral carina on lower half, without oblique carina. Coxae normal shape, without tubercle. Fore trochanter narrow, longer than wide. Basitibial plate of hind leg carinate marginally. Inner hind tibial spur with 3-4 slender teeth as in Fig. 20G (n=6). Fore wing with three submarginal cells.

AвDomen. Disc of T1 with moderately dense distinct PP on medial area and with lineolation on anterior and medial areas (lineolation reaching punctate zone on medial area, but interrupted on submedial patch) (Fig. 16C). Disc of T2-T3 nearly smooth on medial area, and very weakly lineolate on remaining part. Disc of T4 with very weak lineolation over entire surface.

\section{Male}

Not examined in the present study.

\section{Variation}

Disc of T1 distinctly lineolate over entire surface in three specimens collected from Hachijo Is., Japan.

\section{Distribution}

Japan (Hokkaido, Honshu, Kyushu, Izu-shotô Islands), Korean Peninsula, Russian Far East, China.

\section{Flight period}

Female: June to September.

Males have been collected from July to August in the Korean Peninsula (Ebmer 1978b).

\section{Flower records}

The specimens examined in this paper were collected on the flowers of 26 species in 13 families as follows. Apiaceae: Aegopodium podagraria L. Araliaceae: Aralia cordata Thunb. Asteraceae: 
Argyranthemum frutescens (L.) Sch.Bip.; Erigeron annuus (L.) Pers.; Hieracium umbellatum L.; Inula salicina L. var. asiatica Kitam.; Leontodon taraxacoides (Vill.) Mérat; Picris hieracioides L. subsp. japonica (Thunb.) Krylov; Rudbeckia laciniata L.; Solidago virgaurea L. subsp. leiocarpa (Benth.) Hultén; Sonchus brachyotus DC.; Sonchus sp.; Taraxacum sp. Brassicaceae: Brassica rapa L. var. oleifera DC. Convolvulaceae: Calystegia pubescens Lindl. Fabaceae: Trifolium pratense L.; Trifolium repens L. Geraniaceae: Geranium sp.; Geranium yesoense Franch. \& Sav. var. pseudopalustre Nakai.
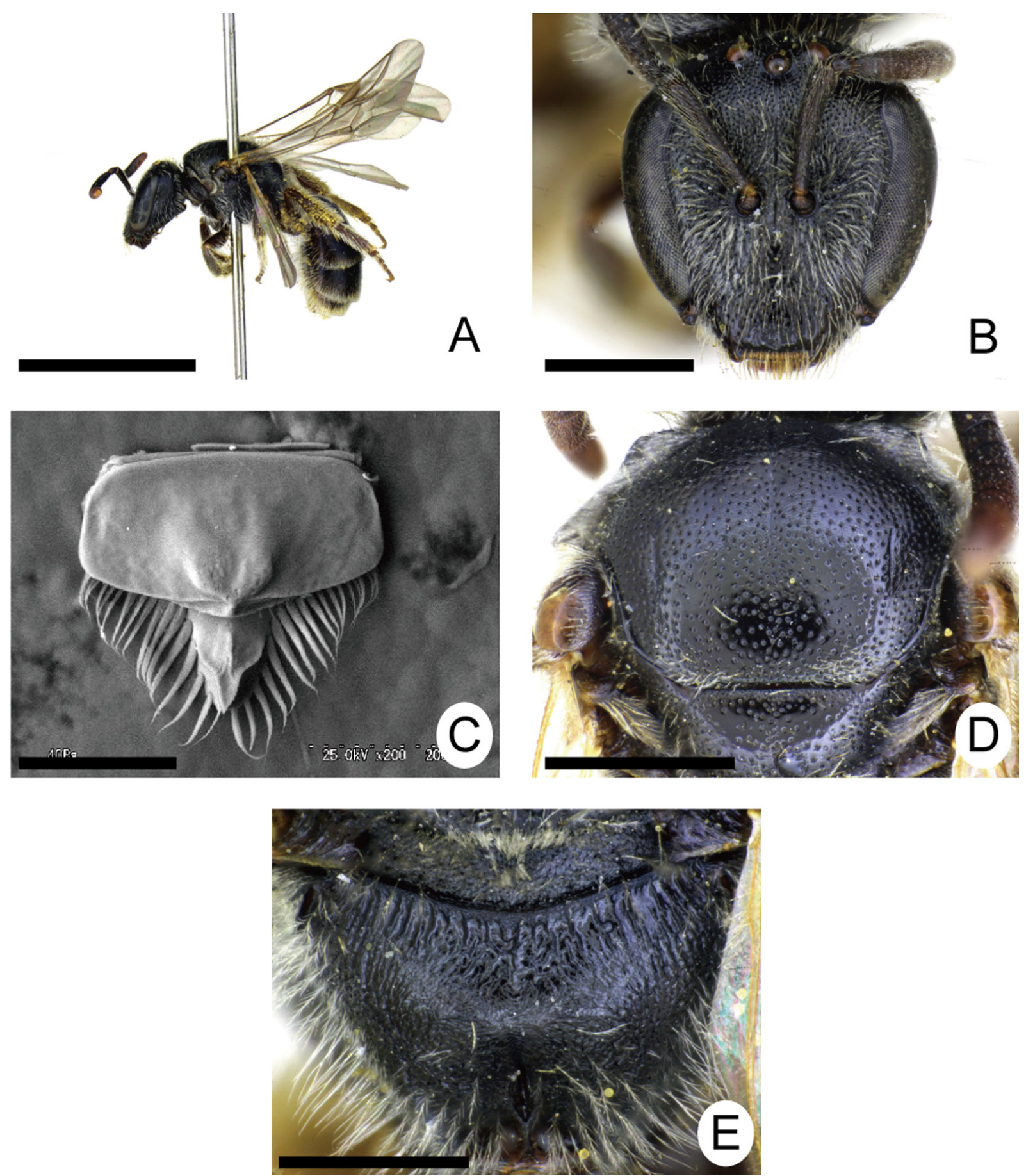

Fig. 11. Lasioglossum (Hemihalictus) speculinum (Cockerell, 1925), ․ . A. Lateral habitus. B. Head in frontal view. C. Labrum. D. Mesoscutum. E. Metapostnotum. Scale bars: A $=3 \mathrm{~mm}$; B, D-E, $=0.5 \mathrm{~mm}$; $\mathrm{C}=0.2 \mathrm{~mm}$. 
Hypericaceae: Hypericum erectum Thunb. Lamiaceae: Lavandula angustifolia Mill. Oxalidaceae: Oxalis corniculata L. Ranunculaceae: Ranunculus repens L. Rosaceae: Rosa multiflora Thunb.; Rosa rugosa Thunb. Rubiaceae: Galium verum L. subsp. asiaticum (Nakai) T.Yamaz. var. asiaticum Nakai f. lacteum (Maxim.) Nakai.

Lasioglossum (Hemihalictus) sphecodicolor Sakagami \& Tadauchi, 1995

Figs 12, 16D, 18A, 20H

Lasioglossum (Evylaeus) sphecodicolor Sakagami \& Tadauchi, 1995: 191, figs 52, 55, 57, 59, 61-65, 67-68 (욱) (holotype: Systematic Entomology, Faculty of Agriculture, Hokkaido University, Japan, + , type locality= Takizawa Experim. Forest, Iwate Pref., N. Honshu, Japan).

\section{Diagnosis}

Females are similar to L. (H.) eidmanni (Blüthgen, 1930). According to Sakagami \& Tadauchi (1995), this species is only separated from $L$. (H.) eidmanni by the metasomal terga without distinct apical fimbriae. In contrast, in L. (H.) eidmanni, the metasomal terga have more or less dense and welldeveloped apical fimbriae.

\section{Material examined}

Paratypes

JAPAN - Honshu • 2 q + ; Iwate Pref., Takizawa, Exp. For.; 27 Jul. 1976; Y. Maeta and T. Matsumura leg.; MNHAH • 1 q; Kyoto Pref., Ashu; 19 Jul. 1984; T. Inoue, T. Ichino, H. Ichihashi and M. Kato leg.; MNHAH • 1 क; Kyoto Pref., Kibune, Asoga; 28 Jun. 1984; M. Kato leg.; MNHAH.

\section{Other material}

JAPAN - Honshu • 1 \%; Akita Pref., Omonogawa-machi, Fukai; 7 Jun. 1978; K. Baba and N. Kato leg.; ELKU • 1 q; Iwate Pref., Morioka, Kuriyagawa; 2 Jun. 1964; Y. Maeta leg.; ELKU • 1 ; ; same location as for preceding; 23 Jun. 1964; Y. Maeta leg.; ELKU • 1 \%; Miyagi Pref., Onoda-cho, Arasawa; 29 Jun. 2000; K. Gôkon leg.; cGou • 1 क; Miyagi Pref., Kawatabi; 22 Jun. 1986; K. Gôukon leg.; cGou • 1 क; Yamagata Pref., Oguni-machi, Tamagawa; 24 Jun. 1981; K. Baba leg.; ELKU • 1 q; Fukushima Pref., Kôriyama, Nakayama; 23 May 1975; O. Tadauchi leg.; ELKU • 1 क; Tochigi Pref., Nasu-machi, Moriko; 22 May 1975; O. Tadauchi leg.; ELKU • 1 q; Gunma Pref., Naganohara, Asamabokujyo; 19 Jul. 1967; T. and H. Suda leg.; ELKU • 1 क; Niigata Pref., Miomote; 13 Jun. 1977; K. Baba leg.; ELKU • 1 \%; same location as for preceding; 10 Jul. 1981; K. Baba leg.; ELKU • 1 क; Niigata Pref., Kurokawa; 9 Aug. 1970; K. Baba leg.; ELKU • 2 क $\%$; same location as for preceding; 8 Jul. 1981; K. Baba leg.; ELKU • 1 q; same location as for preceding; 23 May 1985; K. Baba leg.; ELKU • 1 \%; same location as for preceding; 16 Jul. 1985; K. Baba leg.; ELKU • 1 क; Niigata Pref., Asahi, Koage; 15 Jun. 1985; K. Baba leg.; ELKU • 2 우; Niigata Pref., Senami; 17 Jun. 1977; K. Baba leg.; ELKU • 1 q; same location as for preceding; 23 Jun. 1985; K. Baba leg.; ELKU • 1 q; Niigata Pref., Shibatashi, Kawahigashi; 22 May 1977; K. Baba leg.; ELKU • 1 q; Niigata Pref., Yuzawa, Mitsumata; 19 Jun. 1977; K. Baba leg.; ELKU • 1 q; Niigata Pref., Yuzawa-machi, Hiuchi-toge; 20 Jun. 1982; K. Baba leg.; ELKU • 3 q ; ; Niigata Pref., Asahi, Waseda; 23 May 1985; K. Baba leg.; ELKU • 1 \%; Yamanashi

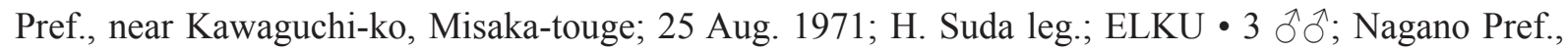
Aburakisawa; 5 Sep. 2014; S. Sawada leg.; cMur • 1 o; Ishikawa Pref., Shishiku; 3 Sep. 1972; I. Togashi leg.; ELKU. - Kyushu • 2 우; Miyazaki Pref., Ebino-Kobayashi-shi; 2 Jun. 2002; K. Mitai leg.; cMur.

\section{Distribution}

Japan (Hokkaido, Honshu, Izu-shotô Islands, Shikoku, Kyushu, Tsu-shima Is., northern Ryukyus). 


\section{Flight period}

Female: April to October.

Male: August to October. The flight records of male are based on the collection data of the original description of this species (Sakagami \& Tadauchi 1995).
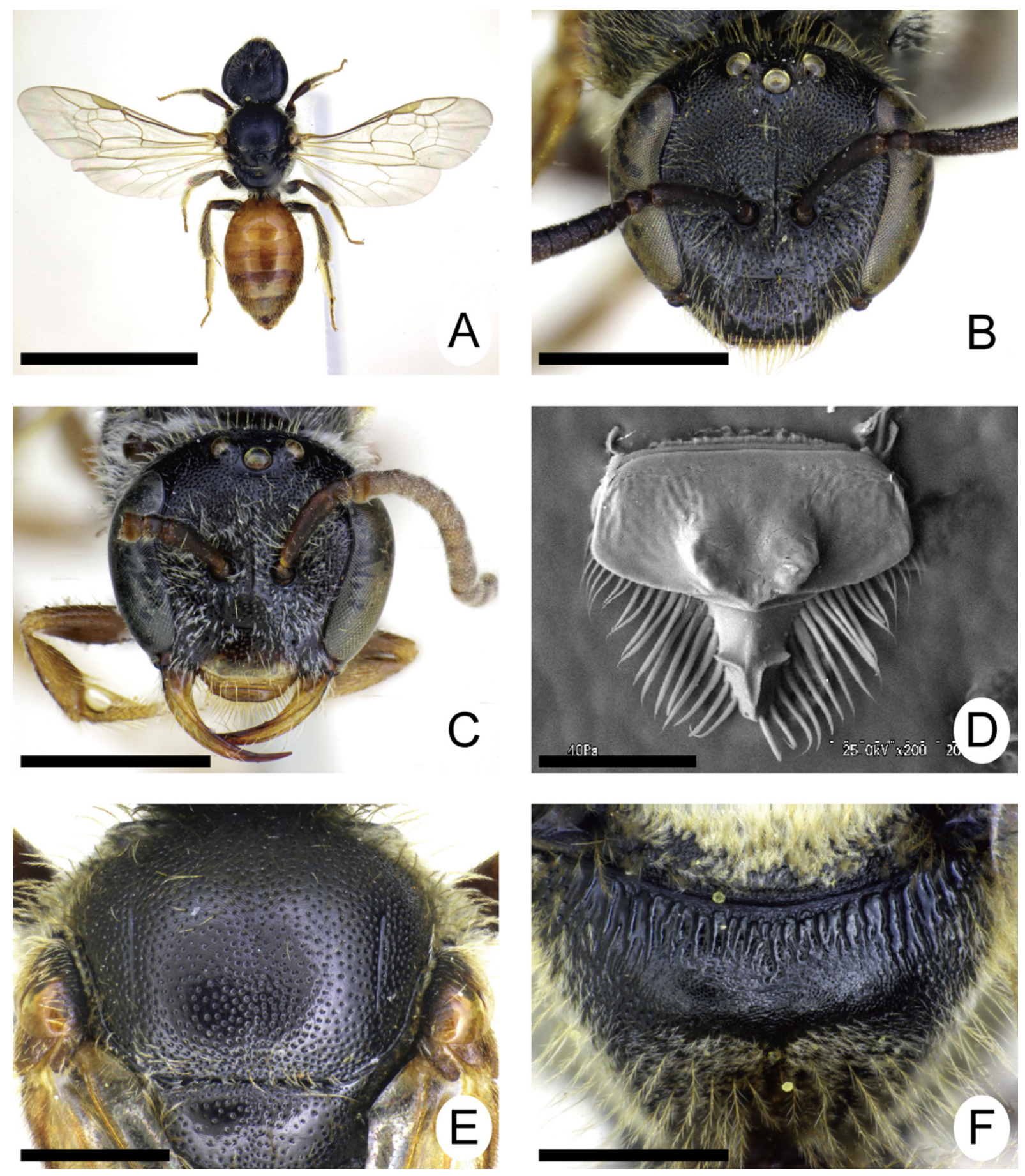

Fig. 12. Lasioglossum (Hemihalictus) sphecodicolor Sakagami \& Tadauchi, 1995. A. + , dorsal habitus. B. , , head in frontal view. C. $\curvearrowright$, head in frontal view. D. $q$, labrum. E. $q$, mesoscutum. F. $ᄋ$, metapostnotum. Scale bars: A $=3 \mathrm{~mm}$; $-\mathrm{C}=1 \mathrm{~mm} ; \mathrm{D}=0.2 \mathrm{~mm}$; $\mathrm{E}-\mathrm{F}=0.5 \mathrm{~mm}$. 
MURAO R., Redifition and revision of the Lasioglossum sexstrigatus group in Japan

\section{Flower records}

Astilbe odontophylla Miq. (Saxifragaceae), Deutzia crenata Siebold \& Zucc. (Hydrangeaceae), Hydrangea serrata (Thunb.) Ser. var. serrata (Hydrangeaceae), Persicaria manshuricola Kitag. (Polygonaceae), and Taraxacum officinale Weber ex F.H.Wigg. (Asteraceae).

Lasioglossum (Hemihalictus) subsimplicior sp. nov. urn:lsid:zoobank.org:act:D4408B7F-6A84-4BB2-8B5D-8B9FDF35E031

Figs $13,16 \mathrm{E}, 18 \mathrm{~B}$

\section{Diagnosis}

Females are similar to $L$. $(H$.) simplicior but are separated from them by the lineolation of T1 interrupted in part (Fig. 16E). In contrast, in L. (H.) simplicior, the lineolation of $\mathrm{T} 1$ is present across the entire surface (Fig. 15E).

\section{Etymology}

The specific name is derived from this species' similarity to L. (H.) simplicior (Cockerell, 1931).

\section{Material examined}

\section{Holotype}

JAPAN - Kyushu - ; ; Oita Pref., Kusu-gun, Kokonoe-machi, Chojyabaru; 33²76.773" N, 131¹3'49.331" E; 1050 m a.s.1.; 13 Aug. 2010; Y. Murao leg.; ELKU.

[Verbatim label: JAPAN: Kyushu/Chojyabaru/Kokonoe-machi/Kusu-gun/Oita Pref./13. VIII. 2010/Yumi Murao leg. // HOLOTYPE // Lasiioglossum (Hemihalictus) subsimplicior Murao]

\section{Paratypes}

JAPAN - Hokkaido • 4 + $\odot$; Antaroma-Aizankei (Ishikari); 26 Jul. 1952; T. Shirôzu leg.; ELKU. Honshu • 1 क; Ishikawa Pref., Negami-machi, Yamaguchi; 29 Aug. 1996; I. Togashi leg.; ELKU. -

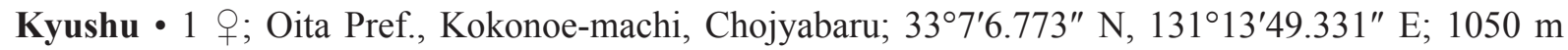
a.s.1.; 13 Aug. 2010; R. Murao leg.; cMur • 2 우; Oita Pref., Kusu-gun, Kokonoe-machi, Handa-kogen;

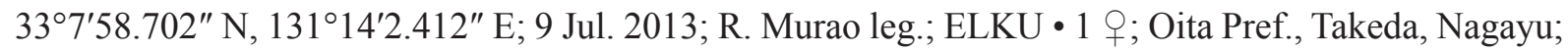
28 Apr. 2009; O. Tadauchi leg.; ELKU • 1 क; Oita Pref., Mt Kuju; 9 May 2009; O. Tadauchi leg.; ELKU • 2 q 9 ; same location as for preceding; 23 May 2009; O. Tadauchi leg.; ELKU • 2 q 9 ; Oita Pref., Shimohanda; 12 Apr. 1975; O. Tadauchi leg.; ELKU• 1 क; Miyaji-Bochu (Mt Aso); 23 Jun. 1959; Y. Hirashima leg.; ELKU • 1 q; Kumamoto Pref., Aso-machi, Aso; 28 May 2001; A. Yamada leg.; ELKU • 1 क; same location as for preceding; 16 Jun. 2001; A. Yamada leg.; ELKU • 1 \%; Miyazaki Pref., Takachiho-cho, Gokasyo-Sobosan; 27 Apr. 2003; F. Kodoi leg.; ELKU • 2 우; MiyakonojoHyuga, Nakao; 13 Apr. 1958; Y. Hirashima leg.; ELKU • 2 qo ; Makizono (Satsuma); 11 Apr. 1959; Y. Hirashima leg.; ELKU • 2 o $о$; Kagoshima; 4 Apr. 1949; Y. Hirashima leg.; ELKU • 1 o; Sata (Osumi) Magome-Hetsuka; 24 May 1952; T. Esaki and Y. Hirashima leg.; ELKU • 1 क; Kagoshima Pref., Kiire-machi, Kiire; 31 Mar. 1975; O. Tadauchi leg.; ELKU • 1 \&; Kagoshima Pref., Miyakonojo; 29 Mar. 1959; Y. Maeta leg.; ELKU. - Ryukyus • 1 क; Kagoshima Pref., Yaku-shima, Onoaida; 40 200 m a.s.1.; 27 Jul. 1982; S. Ikudome leg.; KWC.

SOUTH KOREA - Jeollabuk-do • 1 q; Namweon-gun, Sannae-myon, Sanlyong-ri; 14 May 1991; O. Tadauchi leg.; ELKU. - Gyeongsangnam-do • 1 क; Hamyang-gun, Macheongmeon, Samjeong-ri; 12 May 1991; T. Saigusa leg.; ELKU. 


\section{Description}

Female

Measurements $(\mathrm{n}=5$, unit $\mathrm{mm}) . \mathrm{BL}=5.00-5.63(5.45 \pm 0.27), \mathrm{WL}=4.63-5.00(4.80 \pm 0.14), \mathrm{HL}=1.55-$ $1.65(1.59 \pm 0.04), \mathrm{HW}=1.61-1.74(1.69 \pm 0.05), \mathrm{IOD}=0.27-0.29 \quad(0.28 \pm 0.01), \quad \mathrm{OOD}=0.26-0.29$ $(0.28 \pm 0.01), \mathrm{OCD}=0.19(0.19 \pm 0.00), \mathrm{UOD}=1.00-1.06(1.02 \pm 0.03), \mathrm{MOD}=1.16-1.26(1.21 \pm 0.04)$, $\mathrm{LOD}=0.87-0.94 \quad(0.89 \pm 0.03), \quad \mathrm{IAD}=0.13-0.15 \quad(0.14 \pm 0.01), \quad \mathrm{AOD}=0.29-0.31 \quad(0.30 \pm 0.01)$, $\mathrm{CAL}=0.27-0.29(0.29 \pm 0.01), \mathrm{CPL}=0.32-0.34(0.34 \pm 0.01), \mathrm{EL}=1.85-1.90(1.88 \pm 0.03), \mathrm{EW}=0.42-$ $0.48(0.46 \pm 0.03), \mathrm{GW}=0.29-0.32 \quad(0.31 \pm 0.02), \quad \mathrm{SPL}=0.63-0.68 \quad(0.65 \pm 0.02), \quad \mathrm{F} 1 \mathrm{~L}=0.08-0.10$ $(0.09 \pm 0.01), \quad \mathrm{F} 2 \mathrm{~L}=0.08 \quad(0.08 \pm 0.00), \quad \mathrm{F} 3 \mathrm{~L}=0.08 \quad(0.08 \pm 0.00), \quad \mathrm{F} 2 \mathrm{~W}=0.13-0.15 \quad(0.14 \pm 0.01)$, $\mathrm{MsW}=1.85-2.10 \quad(1.98 \pm 0.09), \quad \mathrm{SCL}=0.40-0.45 \quad(0.42 \pm 0.03), \quad \mathrm{MNL}=0.23-0.25 \quad(0.25 \pm 0.01)$, $\mathrm{MPL}=0.28-0.30(0.28 \pm 0.01), \mathrm{MtW}=1.95-2.15(2.04 \pm 0.07)$.

Coloration. Body black except for the following parts: mandible reddish brown apically; F4-F10 yellowish brown (holotype and 18 paratypes) or brown (reamining paratypes) ventrally; tegula yellowish brown translucent; tibial spur yellow; metasomal terga broadly yellowish brown translucent apically. Wings transparent, veins and stigma brown.

PuBESCENCE. Body hairs whitish, and covered with erect and sparse straight or fine branched hairs except for the following parts: pronotal dorsum to lobe and metanotum moderately densely tomentose; hind trochanter, femur, and tibia mixed with plumose hairs, forming scopa. Disc of T1 with sparse short hairs on medial area. Discs of T2-T4 with moderately dense short hairs over entire surface.

Structure And sculpture head. Wider than long; $\mathrm{HW}: \mathrm{HL}=1: 0.94$. Vertex rounded in frontal view. MOD:UOD:LOD=1:0.84:0.74. IOD:OOD:OCD=1:0.99:0.69. IAD:AOD=1:2.11. Ocellocular area densely puctate, IS nearly smooth (IS $=0.5-2 \mathrm{~d}$ ). Paraocular area and frons weakly shiny, with shallow reticulate PP. Supraclypeal area slightly convex, dimly shiny, with dense PP; IS distinctly tessellate $(\mathrm{IS}=0.5-2 \mathrm{~d})$. CPL:CAL=1:0.86. Clypeus nearly flat, with dense PP on upper half and larger shallow PP on lower half; IS nearly smooth over entire surface (IS $=0.5-1 \mathrm{~d}$ on upper half). $\mathrm{EW}: \mathrm{GW}=1: 0.68$. Genal area to postgena with straight ridges. Malar space linear. Occiput not carinate. Hypostomal carinae nearly parallel. Mandible bidentate. Labrum (Fig. 13C): basal area approximately $2 \times$ as wide as long; distal process approximately $0.7 \times$ as long as basal area, narrow, and without lateral projection; distal keel narrow, pointed apically. Antenna short, not reaching metasoma. F2L:F2W=1:1.76; flagellum nearly flattened ventrally.

Thoirax. Dorsolateral angle of pronotum obtuse; lateral surface without ridges; lateral lobe rounded. Tegula ovoid, nearly smooth. Mesoscutum (Fig. 13D) with dense PP over entire surface; IS distinctly tessellate nearly over entire surface (but weakly tessellate on posterior margin) (IS $=0.5-2 \mathrm{~d}$ ); parapsidal line a narrow groove. Mesoscutellum with moderately dense PP over entire surface; IS weakly tessellate over entire surface (IS=0.5-3 d in paratypes). Metanotum weakly rugulose. Mesepisternum with reticulate PP on upper area and weak rugulae on lower area. SCL:MNL:MPL=1:0.58:0.67. Propodeum: metapostnotum (Fig. 13E) weakly shiny and gently inclined, with straight ridges reaching to near posterior margin; junction between metapostnotum and posterior surface not carinate, weakly tessellate; lateral surface weakly rugulose and distinctly tessellate; posterior surface with lateral carina on lower half, without oblique carina. Coxae normal shape, without tubercle. Fore trochanter narrow, longer than wide. Basitibial plate of hind leg carinate marginally. Inner hind tibial spur with 3-4 slender teeth $(\mathrm{n}=27)$. Fore wing with three submarginal cells.

ABDOMEN. Disc of T1 with weak lineolation interrupted on medial area (Fig. 16E), and with sparse fine PP on medial area; submedian patch distinct and nearly smooth. Disc of T2-T3 with very weak lineolation on apical half, and without lineolation on basal half. T4 very weakly lineolate over entire surface. 
Male

Unknown.

\section{Distribution}

Japan (Hokkaido, Honshu, Kyushu, northern Ryukyus), Korean Peninsula.
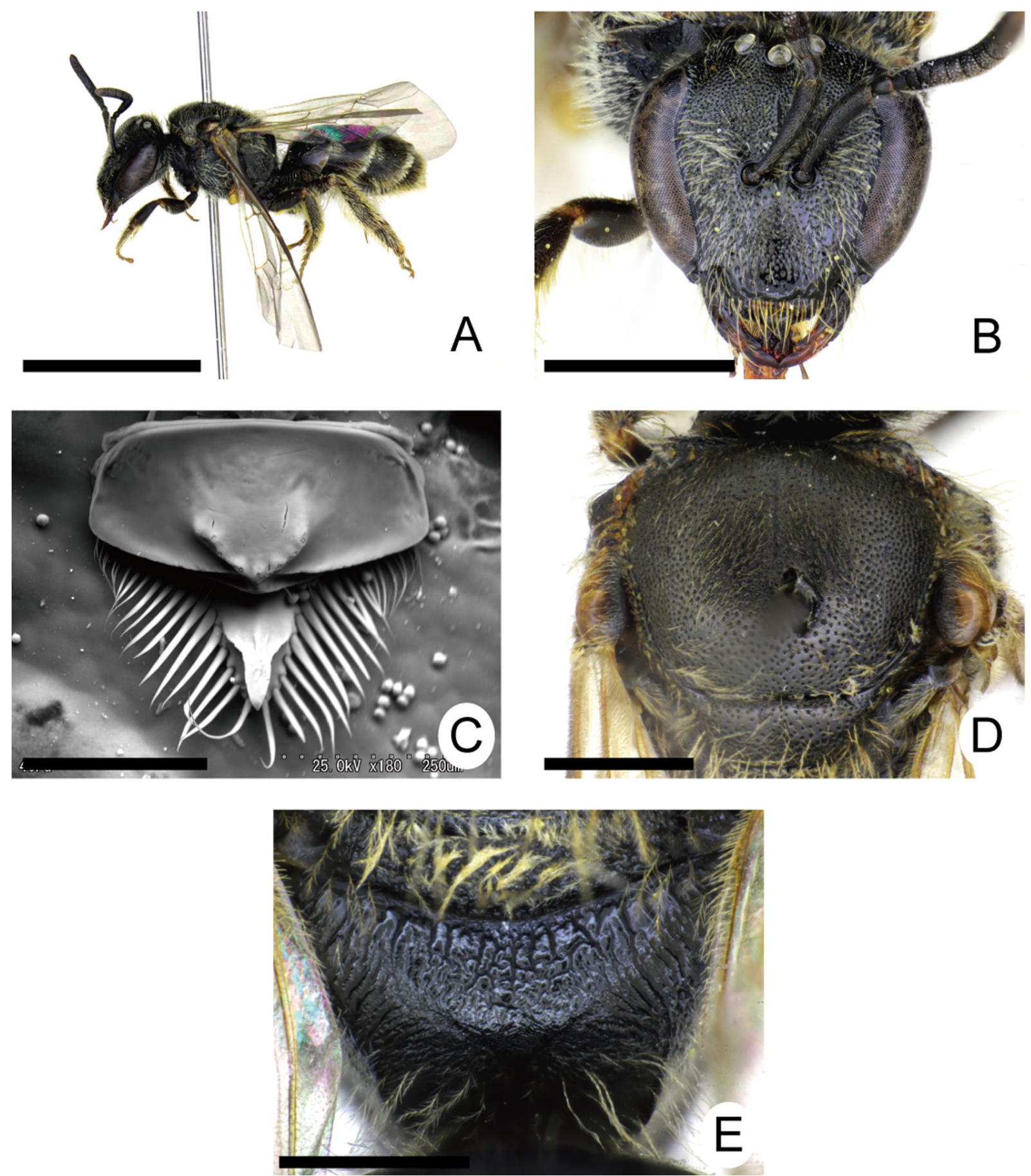

Fig. 13. Lasioglossum (Hemihalictus) subsimplicior sp. nov., ㅇ. . A. Lateral habitus. B. Head in frontal view. C. Labrum. D. Mesoscutum. E. Metapostnotum. Scale bars: A $=3 \mathrm{~mm} ; \mathrm{B}=1 \mathrm{~mm} ; \mathrm{C}=0.25 \mathrm{~mm}$; $\mathrm{D}-\mathrm{E}=0.5 \mathrm{~mm}$. 


\section{Flight period}

Female: late March to August.

\section{Flower records}

Brassica rapa L. var. oleifera DC. (Brassicaceae), Eleutherococcus sp. (Araliaceae), Erigeron annuus (L.) Pers. (Asteraceae), Ixeridium dentatum (Thunb.) Tzvelev subsp. dentatum (Asteraceae).

\section{Habitat}

This species has been collected mainly from mountainous areas in western Japan. One of the collecting sites in Japan is shown in Fig. 19A.

Lasioglossum (Hemihalictus) tadauchii Murao, 2012

Fig. 18D

Lasioglossum (Evylaeus) tadauchii Murao, 2012: 91, figs 1-14 (†) (holotype: ELKU, + , type locality = Nishinakama, Amami-Ôshima., Kagoshima Pref., Ryukyus, Japan, examined).

\section{Diagnosis}

Females are similar to L. (H.) taeniolellum. According to Murao (2012), this species is separated from $L$. $(H$.) taeniolellum by the postgena having distinct lineolation over entire surface, the distal process of labrum without lateral projection (Murao 2012: fig. 5), and T1 with short hairs and fine PP on disc (Murao 2012: fig. 7). In contrast, in L. (H.) taeniolellum, the lineolation on postgena does not reach the apical margin, the distal process of labrum with horn-like lateral projection (Fig. 14D), and T1 nearly smooth. Male unknown.

\section{Distribution}

Japan (central Ryukyus: Amami-Ohshima Is.).

\section{Flight records}

Female: April to October.

\section{Flower records}

Two species in two families were reported as floral records by Murao (2012).

\section{Habitat}

This species has been collected from around subtropical forests in mountainous area (Murao 2012). It may prefer humid environments.

\section{Lasioglossum (Hemihalictus) taeniolellum (Vachal, 1903)}

Figs 2B, 14, 16F, 18C, 20I

Halictus taeniolellus Vachal, 1903: 131 (holotype: Muséum national d'histoire naturelle, Paris, France, + , type locality = Japan).

Halictus subfamiliaris Strand, 1910: 191 (holotype: ZMHB, + , type locality=Japan, examined). Synonymy by Ebmer (1978b).

Lasioglossum (Evylaeus) taeniolellum - Ebmer 1978b: 315. 


\section{Diagnosis}

Females are similar to $L$. (H.) tadauchii, but are separated from them by the lineolation on postgena not reaching the apical margin, the distal process of the labrum with a horn-like lateral projection (Fig. 14D), and T1 nearly smooth. In contrast, in $L$. (H.) tadauchii, the postgena have a distinct lineolation across the entire surface, the distal process of the labrum is without a lateral projection (Murao 2012: fig. 5), and T1 has short hairs and fine PP on the disc (Murao 2012: fig. 7).
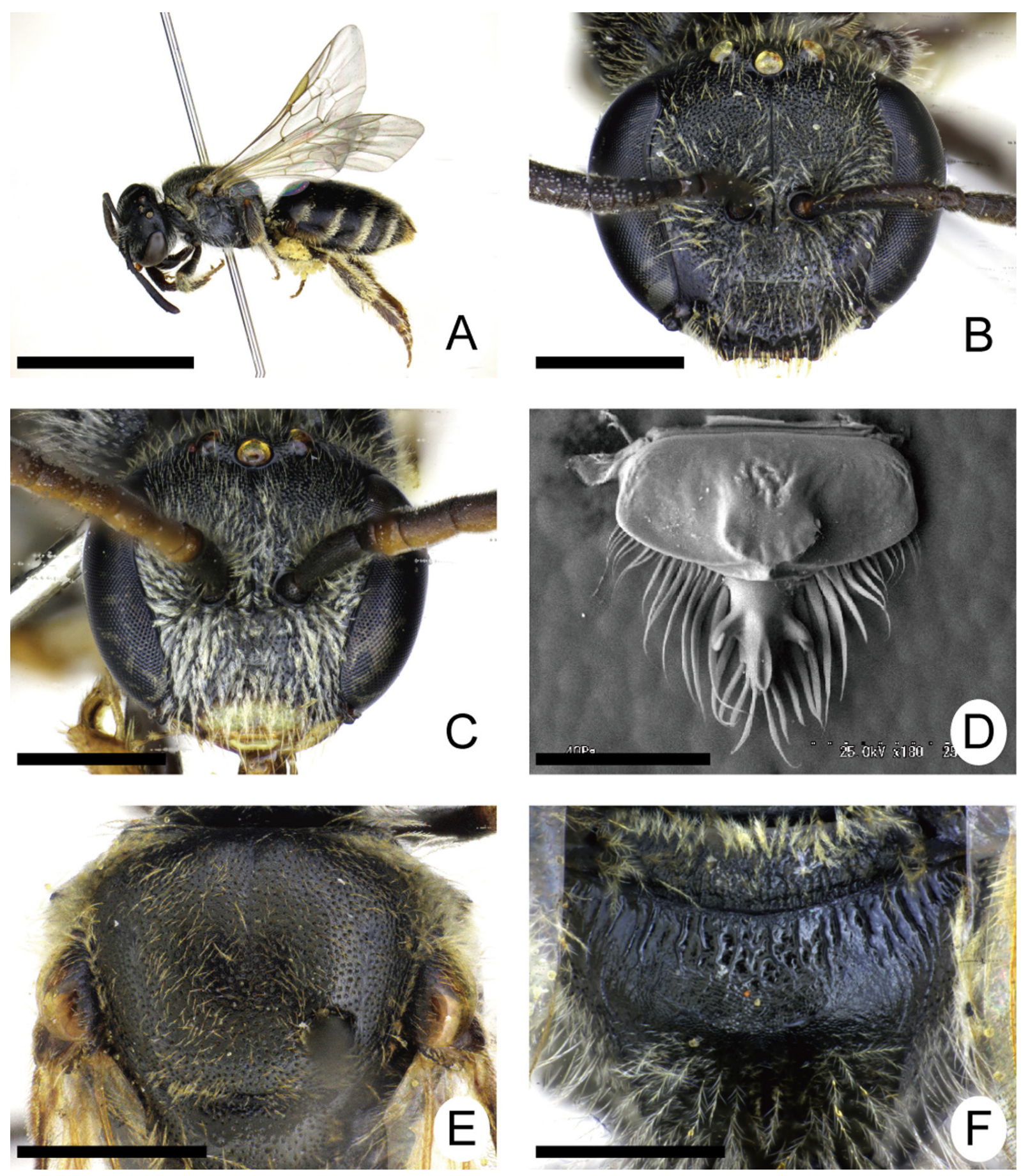

Fig. 14. Lasioglossum (Hemihalictus) taeniolellum (Vachal, 1903). A. + , lateral habitus. B. $q$, head in frontal view. C. $\delta$, head in frontal view. D. $q$, labrum. E. $q$, mesoscutum. F. $q$, metapostnotum. Scale bars: $\mathrm{A}=3 \mathrm{~mm}$; $\mathrm{B}-\mathrm{C}, \mathrm{E}-\mathrm{F}=0.5 \mathrm{~mm}$; $\mathrm{D}=0.25 \mathrm{~mm}$. 


\section{Material examined}

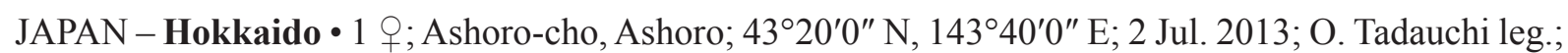
ELKU • 1 क; Nishiashoro (Tokachi); 8 Aug. 1955; Y. Hirashima leg.; ELKU • 1 \&; Ashoro-gun, Metou; 19 Jun. 1957; M. Takahashi leg.; ELKU • 1 क; Sapporo, Hokkaido Univeristy Campus; 3 Sep. 1969; S.F. Sakagami leg.; MNHAH • 1 q; Ebetsubuto; 8 May 1974; M. Ishikawa leg.; MNHAH. - Honshu • 13 우; Iwate Pref., Morioka, Kuriyagawa; 16 May 1964; Y. Maeta leg.; ELKU • 4 우; same location as for preceding; 2 Jun. 1964; Y. Maeta leg.; ELKU • 1 क; Miyagi Pref., Sendai, Tsuchitoi; 10 May 1977; K. Gôukon leg.; MNHAH • 1 क ; Ibaraki Pref., Tsukuba, Kouyadai; 22 Jun. 1989; T. Matsumura leg.; MNHAH • 1 क; Saitama Pref., Urawa; 24 Aug. 1968; T. Nambu leg.; ELKU • 3 o $\circ$; Yamanashi Pref., Nakagawa; 9 Apr. 1962; T. Saigusa leg; commented by Dr Hirashima as "compared with the type of Halictus taeniolellus Vachal " " the under label; ELKU • 1 क ; Kyoto Pref., Expet. Internal. Forest, Kyoto Univ.; 10 Aug. 1985; T. Kakutani leg.; MNHAH. - Kyushu • 4 q $o$; Fukuoka Pref., Fukuoka-shi, Higashi-ku, Hakozaki, Kyushu Univ.; 10 Jul. 2004; T. Sugimoto leg.; ELKU • 18 q ; same location as for preceding; 18 Apr. 2006; R. Murao leg.; cMur • 1 क; same location as for preceding; 15 Jul. 2006; R. Murao leg.; cMur • 14 우, 5 §ో; same location as for preceding; 5 Jul. 2009; R. Murao leg.; cMur • 1 ; same location as for preceding; 29 Mar. 2012; R. Murao leg.; ELKU • 2 q $O$; Kumamoto Pref., Aso-gun, Aso-machi; 20 Apr. 2001; A. Yamada and M. Nomura leg.; AETU • 1 क ; same location as for preceding; 20 May 2001; A. Yamada leg.; AETU • 2 + $O$; same location as for preceding; 28 May 2001; A. Yamada and M. Nomura leg.; AETU • 7 $q$; ; same location as for preceding; 7 Jun. 2001; A. Yamada and M. Nomrua leg.; AETU -3 o ; ; same location as for preceding; 16 Jun. 2001; A. Yamada and M. Nomura leg.; AETU • 1 q; same location as for preceding; 2 Jul. 2001; A. Yamada leg.; AETU • 1 क; same location as for preceding; 17 Sep. 2001; M. Nomura leg.; AETU • 2 + $q$; same location as for preceding; 20 Oct. 2001; M. Nomura leg.; AETU • 1 q; same location as for preceding; 20 Nov. 2001; M. Nomura leg.; AETU • 3 우; Kumamoto Pref., Aso-gun, Choyo-son; 13 Jun. 2003; D. Kozai and M. Ishida leg.; AETU • 2 + 9 ; same location as for preceding; 21 Jun. 2003; M. Ishida leg.; AETU • 1 क; same location as for preceding; 26 Jun. 2003; M. Ishida leg.; AETU • 1 q; same location as for preceding; 2 Jul. 2003; M. Ishida leg.; AETU • 1 क; Kumamoto Pref., Aso-gun, Choyo-son, Setaura; 9 Jul. 1996; M. Yamada leg.; AETU 1 क ; Kumamoto Pref., Aso-gun, Ozu-machi $\sim$ Choyo-son; 7-9 Oct. 2002; K. Mitai leg.; ELKU • 1 क; Kumamoto Pref., Kikuchi-gun, Ozu-machi; 2 Apr. 2002; T. Sugimoto leg.; AETU • 1 क; same location as for preceding; 25 Apr. 2002; Y. Terada leg.; AETU • 1 o; same location as for preceding; $21 \mathrm{Jul}$. 2002; Y. Terada leg.; AETU • 3 o of; same location as for preceding; 18 Apr. 2003; M. Ishida leg.; AETU • 2 우; same location as for preceding; 28 Apr. 2003; M. Ishida and D. Kozai leg.; AETU • 1 क; same location as for preceding; 9 May 2003; M. Ishida leg.; AETU • 3 우; same location as for preceding; 20 May 2003; D. Kozai and M. Ishida leg.; AETU • 1 q; same location as for preceding; 29 May 2003; M. Ishida leg.; AETU • 3 + $\odot$; same location as for preceding; 5 Jun. 2003; D. Kozai leg.; AETU • 6 क $O$; same location as for preceding; 13 Jun. 2003; M. Ishida and D. Kozai leg.; AETU • 1 ; ; same location as for preceding; 21 Jun. 2003; D. Kozai leg.; AETU • 2 우; same location as for preceding; 5 Jul. 2003; M. Ishida leg.; AETU • 1 क ; same location as for preceding; 26 Jul. 2003; M. Ishida leg.; AETU • 1 क; same location as for preceding; 13 Aug. 2003; M. Ishida leg.; AETU • 3 o 9 ; same location as for preceding; 22 Aug. 2003; M. Ishida and D. Kozai leg.; AETU • 1 क; same location as for preceding; 26 Sep. 2003; M. Ishida leg.; AETU 1 9 ; same location as for preceding; 30 Oct. 2003; M. Ishida leg.; AETU • 2 ; Kumamoto Pref., Aso-gun, Nishihara-mura; 22 Apr. 2000; R. Murao leg.; AETU • 4 o 9 ; same location as for preceding; 29 Apr. 2000; R. Murao and M. Murase leg.; AETU• 1 \%; same location as for preceding; 12 May 2000; M. Murase leg.; AETU • 2 우; same location as for preceding; 20 May 2000; R. Murao and M. Murase leg.; AETU • 4 우; same location as for preceding; 29 May 2000; R. Murao and M. Murase leg.; AETU • 1 +; same location as for preceding; 11 Jun. 2000; R. Murao leg.; AETU • 1 \&; same location as for preceding; 14 Jun. 2000; M. Murase leg.; AETU • 1 क; same location as for preceding; 26 Jun. 2000; R. Murao leg.; AETU • 2 † $\odot$; same location as for preceding; 14 Aug. 2000; R. Murao and M. Murase leg.; AETU • 1 q; same location as for preceding; 16 Aug. 2000; M. Murase leg.; AETU • 1 \%; same location as for preceding; 28 Aug. 2000; M. Murase leg.; AETU • 1 क; same location as for preceding; 1 Oct. 2000; M. Murase 
leg.; AETU • 1 q; same location as for preceding; 6 Nov. 2000; M. Murase leg.; AETU • 2 q $q$; same location as for preceding; 8 Dec. 2000; M. Murase leg., AETU • 8 우; Kumamoto Pref., Kikuchigun, Kikuyo-machi; 22 Apr. 2000; R. Murao and M. Murase leg.; AETU • 8 우; same location as for preceding; 29 Apr. 2000; R. Murao and M. Murase leg.; AETU • 6 우; same location as for preceding; 12 May 2000; R. Murao and M. Murase leg.; AETU $\bullet 7$ q ; same location as for preceding; 20 May 2000; R. Murao and M. Murase leg.; AETU • 15 우; same location as for preceding; 29 May 2000; R. Murao and M. Murase leg.; AETU • 2 क 9 ; same location as for preceding; 14 Jun. 2000; M. Murase leg.; AETU - 5 우; same location as for preceding; 26 Jun. 2000; R. Murao and M. Murase leg.; AETU • 1 क; same location as for preceding; 6 Jul. 2000; M. Murase leg.; AETU • 1 क; same location as for preceding; 16 Aug. 2000; M. Murase leg.; AETU • 1 q; same location as for preceding; 28 Aug. 2000; R. Murao leg.; AETU • 1 क; same location as for preceding; 8 Sep. 2000; M. Murase leg.; AETU • 2 우; same location as for preceding; 19 Sep. 2000; M. Murase leg.; AETU • 5 우; same location as for preceding; 10 Oct. 2000; R. Murao and M. Murase leg.; AETU • 9 q $q$; same location as for preceding; 19 Oct. 2000; R. Murao and M. Murase leg.; AETU • 5 우; same location as for preceding; 27 Oct. 2000; R. Murao and M. Murase leg.; AETU • 1 क; same location as for preceding; 6 Nov. 2000; M. Murase leg.; AETU.

\section{Redescription}

\section{Female}

MEASUREMENTS ( $\mathrm{n}=5$, unit $\mathrm{mm}) . \mathrm{BL}=5.38-5.50(5.35 \pm 0.21), \mathrm{WL}=4.38-4.88(4.55 \pm 0.21), \mathrm{HL}=1.42-$ $1.48(1.45 \pm 0.02), \mathrm{HW}=1.55-1.61 \quad(1.57 \pm 0.03), \quad \mathrm{IOD}=0.29-0.32 \quad(0.30 \pm 0.01), \quad \mathrm{OOD}=0.24-0.29$ $(0.26 \pm 0.02), \quad \mathrm{OCD}=0.18-0.21 \quad(0.19 \pm 0.01), \quad \mathrm{UOD}=0.97-1.00 \quad(0.97 \pm 0.01), \quad \mathrm{MOD}=1.13-1.16$ $(1.15 \pm 0.02), \quad \mathrm{LOD}=0.84-0.90 \quad(0.87 \pm 0.02), \quad \mathrm{IAD}=0.15-0.16 \quad(0.15 \pm 0.01), \quad \mathrm{AOD}=0.29-0.31$ $(0.30 \pm 0.01), \mathrm{CAL}=0.26-0.27(0.26 \pm 0.01), \mathrm{CPL}=0.29-0.32(0.31 \pm 0.02), \mathrm{EL}=1.70-1.75(1.72 \pm 0.03)$, $\mathrm{EW}=0.39-0.45(0.42 \pm 0.03), \mathrm{GW}=0.23-0.35(0.30 \pm 0.05), \mathrm{SPL}=0.61-0.65(0.63 \pm 0.01), \mathrm{F} 1 \mathrm{~L}=0.08-$ $0.10(0.09 \pm 0.01), F 2 \mathrm{~L}=0.08(0.08 \pm 0.00), \mathrm{F} 3 \mathrm{~L}=0.08(0.08 \pm 0.00), \mathrm{F} 2 \mathrm{~W}=0.11-0.13(0.13 \pm 0.01)$, $\mathrm{MsW}=1.80-1.85 \quad(1.83 \pm 0.03), \quad \mathrm{SCL}=0.38-0.40 \quad(0.40 \pm 0.01), \quad \mathrm{MNL}=0.20-0.23 \quad(0.22 \pm 0.01)$, $\mathrm{MPL}=0.25-0.30(0.28 \pm 0.02), \mathrm{MtW}=1.85-2.05(1.90 \pm 0.09)$.

Coloration. Body black except for the following parts: mandible reddish brown apically; all flagellar segments brown or F5-F10 yellowish brown ventrally; tegula yellowish brown translucent; tibial spur yellow; metasomal terga broadly yellowish brown translucent apically. Wings transparent, veins and stigma yellowish brown.

PubesCENCE. Body hairs whitish, and covered with erect and sparse straight or fine branched hairs except for the following parts: pronotal dorsum to lobe and metanotum moderately densely tomentose; posterior surface of propodeum sparsely tomentose; hind trochanter, femur, and tibia mixed with plumose hairs, forming scopa. Disc of T1 without short hairs on medial area. Discs of T2-T4 with moderately dense short hairs over entire surface.

Structure and sculpture head. Wider than long; HW:HL=1:0.92. Vertex rounded in frontal view. MOD:UOD:LOD $=1: 0.85: 0.76$. IOD:OOD:OCD $=1: 0.87: 0.65$. IAD:AOD $=1: 1.96$. Ocellocular area densely puctate, IS nearly smooth (IS $=0.5-2 \mathrm{~d}$ ). Paraocular area and frons weakly shiny, with shallow reticulate PP. Supraclypeal area slightly convex, dimly shiny, with dense PP; IS distinctly tessellate $(\mathrm{IS}=0.5-1.5 \mathrm{~d}) . \mathrm{CPL}: \mathrm{CAL}=1: 0.85$. Clypeus nearly flat, with reticulate PP nearly over entire surface, its PP gradually sparser toward lower area; IS nearly smooth on lower area (IS $=0.5-2 \mathrm{~d}$ on lower area). EW:GW=1:0.71. Genal area with weak straight ridges. Malar space linear. Occiput not carinate. Hypostomal carinae nearly parallel. Postgena weakly tessellate, sometimes nearly smooth in part. Mandible bidentate. Labrum (Fig. 14D): basal area approximately $2.1 \times$ as wide as long; distal process approximately $0.7 \times$ as long as basal area, narrow, and with horn-like lateral projection; distal keel narrow, pointed apically. Antenna short, not reaching metasoma. F2L:F2W=1:1.56; flagellum nearly flattened ventrally. 
THorax. Dorsolateral angle of pronotum obtuse; lateral surface without ridges; lateral lobe rounded. Tegula ovoid, nearly smooth. Mesoscutum (Fig. 14E) with dense PP over entire surface; IS distinctly tessellate over entire surface (IS $=0.5-2 \mathrm{~d}$ ); parapsidal line a narrow groove. Mesoscutellum with sparse PP on submedian area and denser PP on marginal area; IS nearly smooth over entire surface (IS $=1-3 \mathrm{~d}$ on submedian area, and $0.5-1 \mathrm{~d}$ on marginal area). Metanotum weakly rugulose. Mesepisternum with reticulate PP over entire surface. SCL:MNL:MPL=1:0.56:0.71. Propodeum: metapostnotum (Fig. 14F) weakly shiny and gently inclined, with short straight ridges occupying only anterior half, with weak tessellation on posterior half; junction between metapostnotum and posterior surface not carinate, weakly tessellate; lateral surface weakly rugulose and distinctly tessellate; posterior surface with lateral carina on lower half, without oblique carina. Coxae normal shape, without tubercle. Fore trochanter narrow, longer than wide. Basitibial plate of hind leg carinate marginally. Inner hind tibial spur with 2-5 slender teeth as in Fig. 20I $(n=13)$. Fore wing with three submarginal cells.

ABdomen. Disc of T1 nearly smooth over entire surface (Fig. 16F). Disc of T2 very weakly lineolate in part (only anterior or both anterior and posterior area). T3-T4 very weakly lineolate over entire surface.

\section{First description of male}

Measurements ( $\mathrm{n}=5$, unit $\mathrm{mm}) . \mathrm{BL}=3.92-5.23(4.68 \pm 0.56), \mathrm{WL}=3.23-4.00(3.71 \pm 0.27), \mathrm{HL}=1.18-$ $1.44(1.32 \pm 0.10), \mathrm{HW}=1.27-1.51 \quad(1.41 \pm 0.09), \mathrm{IOD}=0.22-0.31 \quad(0.28 \pm 0.03), \quad \mathrm{OOD}=0.24-0.27$ $(0.25 \pm 0.01), \quad \mathrm{OCD}=0.18-0.22 \quad(0.20 \pm 0.02), \quad \mathrm{UOD}=0.84-0.98 \quad(0.92 \pm 0.05), \quad \mathrm{MOD}=0.89-1.07$ $(1.00 \pm 0.06), \quad \mathrm{LOD}=0.60-0.76 \quad(0.70 \pm 0.06), \quad \mathrm{IAD}=0.18-0.22 \quad(0.20 \pm 0.02), \quad \mathrm{AOD}=0.18-0.22$ $(0.20 \pm 0.02), \mathrm{CAL}=0.20-0.27(0.24 \pm 0.02), \mathrm{CPL}=0.29-0.31(0.30 \pm 0.01), \mathrm{EL}=0.87-1.09(0.98 \pm 0.07)$, $\mathrm{EW}=0.40-0.47(0.43 \pm 0.03), \mathrm{GW}=0.27-0.33(0.29 \pm 0.03), \mathrm{SPL}=0.31-0.38(0.35 \pm 0.03), \mathrm{F} 1 \mathrm{~L}=0.09-$ $0.11(0.11 \pm 0.01), \quad \mathrm{F} 2 \mathrm{~L}=0.18-0.22(0.21 \pm 0.02), \quad \mathrm{F} 3 \mathrm{~L}=0.18-0.24 \quad(0.22 \pm 0.02), \quad \mathrm{F} 2 \mathrm{~W}=0.11-0.13$ $(0.12 \pm 0.01), \quad \mathrm{MsW}=1.19-1.48 \quad(1.34 \pm 0.10), \quad \mathrm{SCL}=0.29-0.38 \quad(0.33 \pm 0.03), \quad \mathrm{MNL}=0.13-0.18$ $(0.16 \pm 0.02), \mathrm{MPL}=0.22-0.24(0.23 \pm 0.01), \mathrm{MtW}=1.03-1.29(1.19 \pm 0.02)$.

COLORATION. Body black except for the following parts: lower half of clypeus yellow; mandible except for apically and labrum yellow; mandible apically reddish; all flagellar segments yellowish brown ventrally; pronotal lobe yellow or yellowish brown; tegula yellow translucent; tibiae basally and apically yellow; tibial spur yellow; tarsi yellow; metasomal terga broadly yellowish brown translucent apically. Wings transparent, veins and stigma yellowish brown.

Pubescence. Body hairs whitish, and covered with erect and sparse straight or fine branched hairs except for the following parts: lower paraocular area, supraclypeal area, pronotal dorsum to lobe and metanotum thinly tomentose. Metasomal terga with sparse, simple and short hairs over entire surface.

Structure and sculptuRe head. Wider than long; HW:HL=1:0.93. Vertex rounded in frontal view. MOD:UOD:LOD=1:0.92:0.70. IOD:OOD:OCD $=1: 0.90: 0.71$. IAD:AOD $=1: 1.00$. Ocellocular area with reticulate PP. Paraocular area and frons weakly shiny, with shallow reticulate PP. Supraclypeal area nearly flat, weakly shiny, with moderately dense PP over entire surface; IS nearly smooth $(\mathrm{IS}=0.5-3 \mathrm{~d})$. Clypeus weakly shiny, with dense PP over entire surface; IS nearly smooth (IS $=0.5-1 \mathrm{~d})$. $\mathrm{CPL}: \mathrm{CAL}=1: 0.78$. EW:GW=1:0.68. Genal area with weak straight ridges. Malar space linear. Occiput not carinate. Hypostomal carinae nearly parallel. Postgena longitudinal lineolate. Mandible edentate. Antenna short, not reaching metasoma. F2L:F2W=1:0.58; flagellum nearly flattened ventrally.

Thorax. Dorsolateral angle of pronotum obtuse; lateral surface without ridges; lateral lobe rounded. Tegula ovoid, nearly smooth. Mesoscutum with dense PP over entire surface; IS smooth except for anteriorly weakly tessellate (IS $=0.5-2 \mathrm{~d}$ ); parapsidal line a narrow groove. Mesoscutellum with sparse PP over entire surface; IS smooth (IS=1-5 d). Metanotum weakly rugulose. Mesepisternum with moderately dense PP over entire surface; IS smooth (IS=1-3 d). SCL:MNL:MPL=1:0.49:0.68. Propodeum: metapostnotum shiny and gently inclined, with short straight ridges occupying only 
anterior half, weakly tessellate or nearly smooth on posterior half; junction between metapostnotum and posterior surface not carinate, weakly tessellate or nearly smooth; lateral surface weakly rugulose and distinctly tessellate; posterior surface with lateral carina on lower half, without oblique carina. Coxae normal shape, without tubercle. Fore trochanter narrow, longer than wide. Basitibial plate of hind leg weakly carinate marginally. Inner hind tibial spur without tooth. Fore wing with three submarginal cells.

Abdomen. Disc of T1 without distinct PP and tessellation. Disc of T2-T4 with sparse fine PP, T2 without lineolation, T3 with weak lineolation on apical half, and T4 with weak lineolate over entire surface. S7 with moderately long, apically truncate or rounded median process.

GeNiTALIA. Gonobase flat at bottom; gonocoxite smooth; ventral retrorse lobe tongue-like, moderately long but not reaching gonobase, with sparse short hairs ventrally.

\section{Distribution}

Japan (Hokkaido, Honshu, Izu-shotô Islands, Shikoku, Kyushu, Tsu-shima Is., northern Ryukyus), Korean Peninsula.

\section{Flight period}

Female: April to December.

Males have been collected from August to September in the Korean Peninsula (Ebmer 1978b). In Japan, males have been collected at one site (Hakozaki Campus, Kyushu University, Japan, Fig. 19C) from June to July.

\section{Flower records}

The specimens examined in this paper were collected on the flowers of 46 species in 23 families as follows. Amaranthaceae: Achyranthes bidentata Blume var. japonica Miq.; Amaranthus blitum L. Anacardiaceae: Toxicodendron trichocarpum (Miq.) Kuntze. Asteraceae: Artemisia indica Willd. var. maximowiczii (Nakai) H.Hara; Aster microcephalus (Miq.) Franch. \& Sav. var. ovatus (Franch. \& Sav.) Soejima \& Mot.Ito; Erigeron annuus (L.) Pers.; Erigeron philadelphicus L.; Euchiton japonicus (Thunb.) Anderb.; Lapsanastrum humile (Thunb.) Pak \& K.Bremer; Picris hieracioides L. subsp. japonica (Thunb.) Krylov; Solidago altissima L.; Sonchus asper (L.) Hill; Taraxacum sp.; Youngia japonica (L.) DC. Brassicaceae: Brassica rapa L. var. oleifera DC.; Capsella bursa-pastoris (L.) Medik.; Rorippa indica (L.) Hiern. Campanulaceae: Lobelia chinensis Lour. Caryophyllaceae: Silene armeria L.; Stellaria aquatica (L.) Scop. Commelinaceae: Commelina communis L. Cucurbitaceae: Momordica charantia L. Elatinaceae: Stellaria sp. Ericaceae: Rhododendron sp. Fabaceae: Astragalus sinicus L.; Trifolium dubium Sibth.; Trifolium repens L.; Vicia hirsuta (L.) Gray; Vicia sativa L. subsp. nigra (L.) Ehrh. Geraniaceae: Geranium carolinianum L. Lamiaceae: Lamium album L. var. barbatum (Siebold \& Zucc.) Franch. \& Sav.; Lamium amplexicaule L.; Vitex negundo L. var. cannabifolia (Siebold \& Zucc.) Hand.-Mazz. Mazaceae: Mazus pumilus (Burm.f.) Steenis. Oxalidaceae: Oxalis corniculata L. Papaveraceae: Corydalis incisa (Thunb.) Pers. Plantaginaceae: Veronica persica Poir. Polygonaceae: Persicaria longiseta (Bruijn) Kitag.; Persicaria sagittata (L.) H.Gross var. sibirica (Meisn.) Miyabe. Portulacaceae: Portulaca oleracea L. Ranunculaceae: Ranunculus cantoniensis DC.; Ranunculus sceleratus L. Rosaceae: Kerria japonica (L.) DC. f. albescens (Makino ex Koidz.) Ohwi; Pourthiaea villosa (Thunb.) Decne. var. villosa. Rubiaceae: Paederia foetida L. Solanaceae: Solanum nigrum L.

\section{Habitat}

This species has been collected mainly in cultivated or urban lowland areas and semi-natural grassland in Kyushu, western Japan. One of the collection sites in Japan is shown in Fig. 19C. 


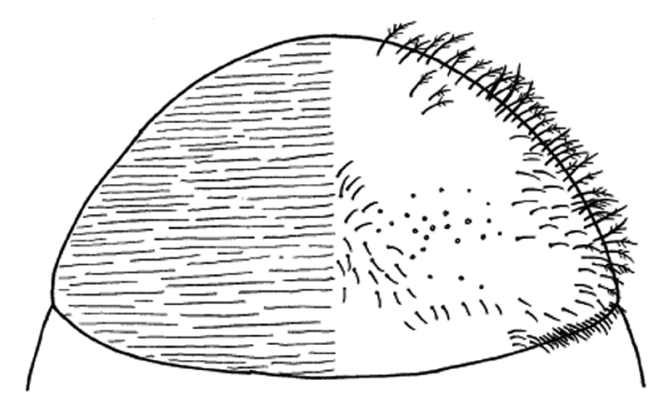

A

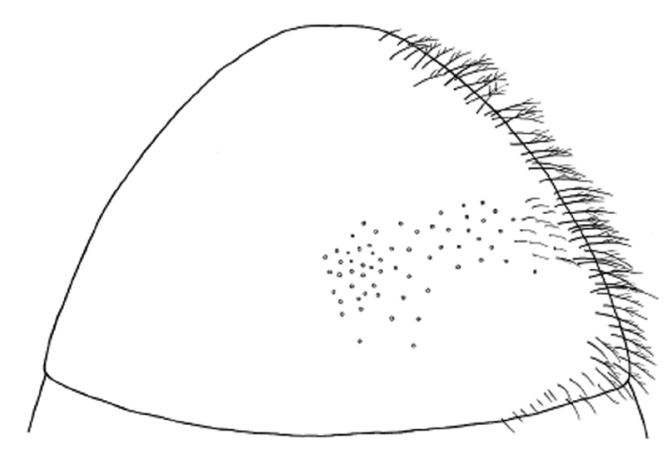

C

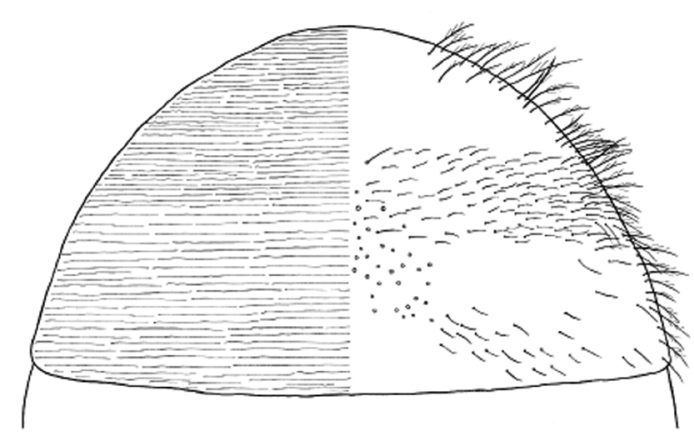

E

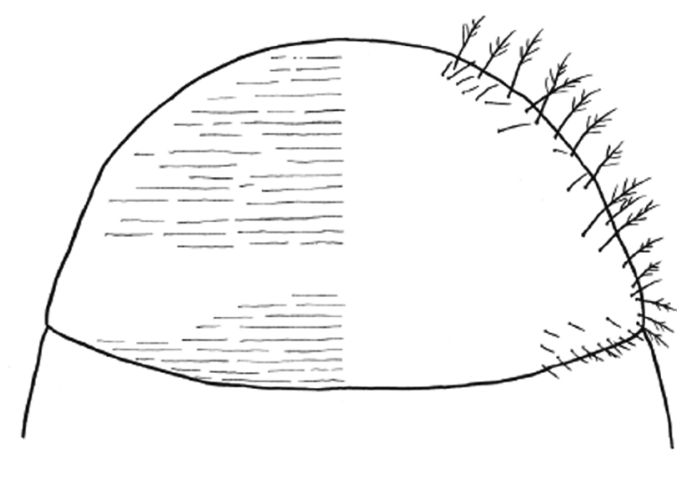

B

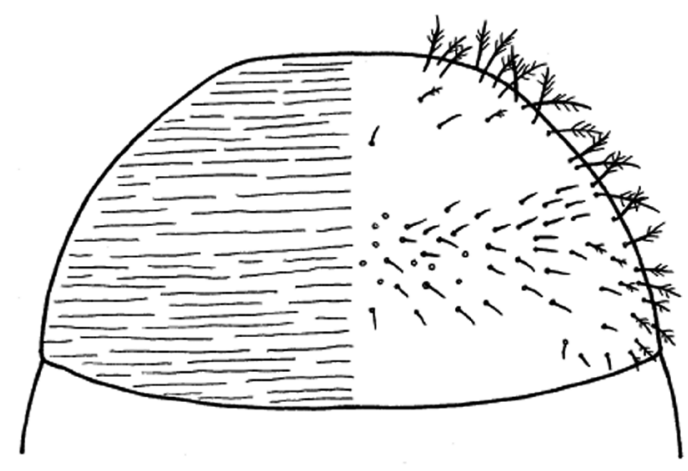

D

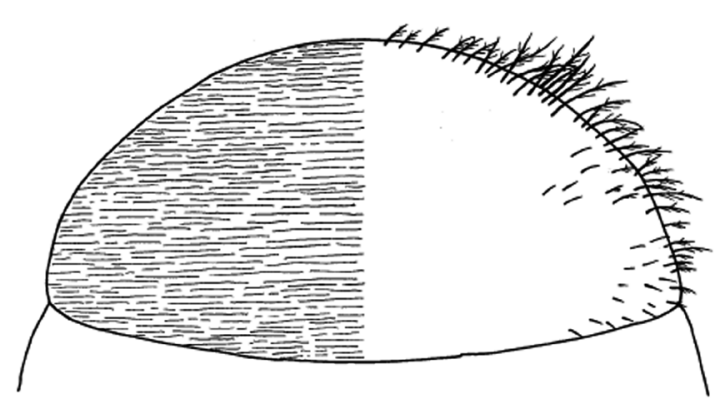

$\mathrm{F}$

Fig. 15. $1^{\text {st }}$ metasomal tergum, ․ A. Lasioglossum (Hemihalictus) frigidum Sakagami \& Ebmer, 1996. B. L. (H.) ikudomei sp. nov. C. L. (H.) kiautschouense (Strand, 1910). D. L. (H.) ohei Hirashima \& Sakagami, 1966. E. L. (H.) simplicior (Cockerell, 1931). F. L. (H.) smilodon Ebmer \& Sakagami, 1994. Scale bars: $1 \mathrm{~mm}$. 


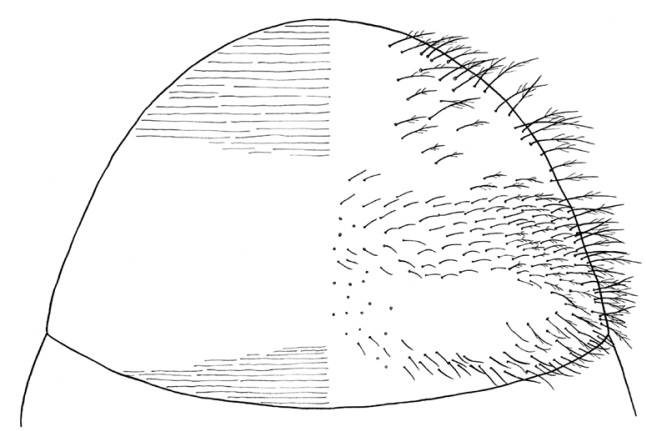

A

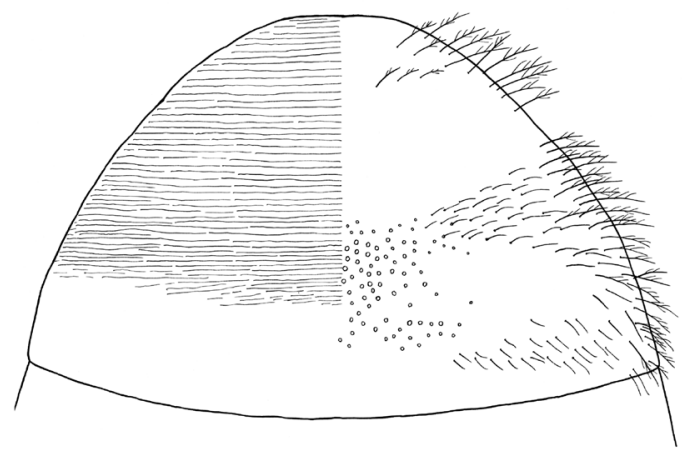

C

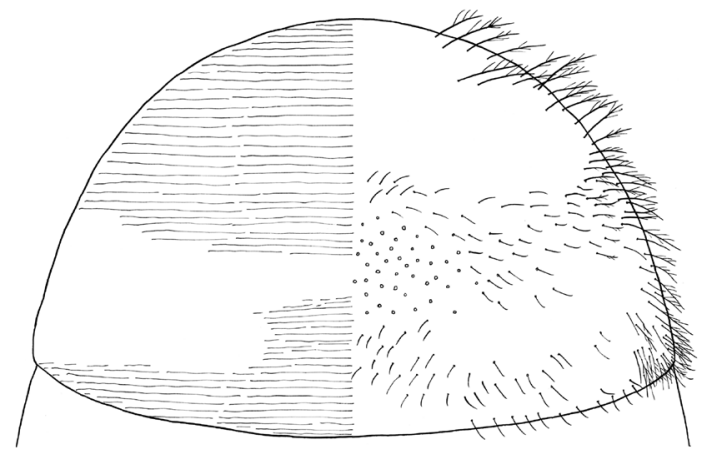

$E$

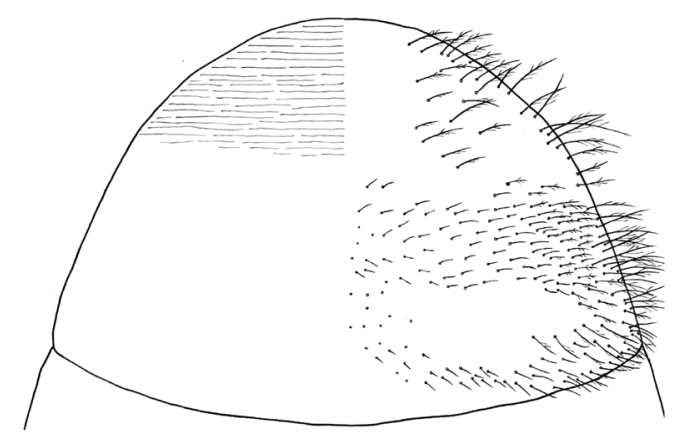

B

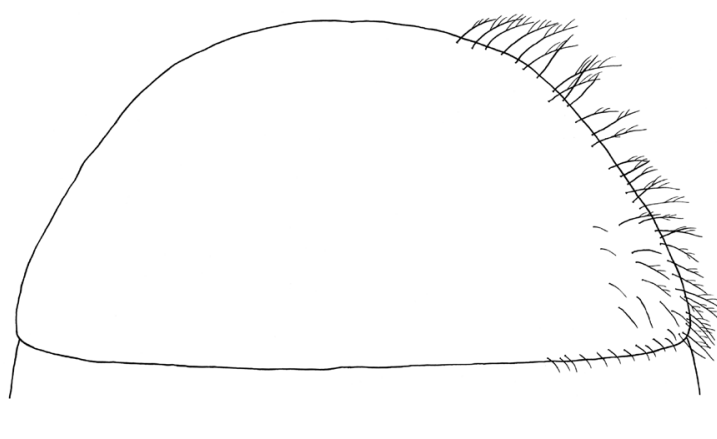

$\mathrm{D}$

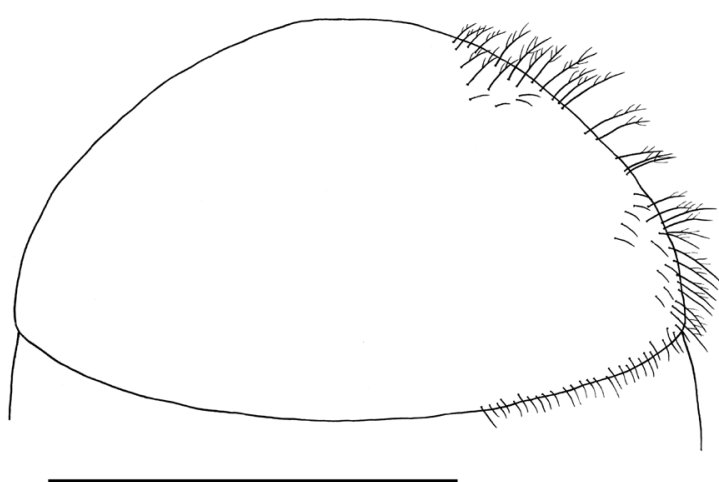

$\mathrm{F}$

Fig. 16. $1^{\text {st }}$ metasomal tergum, + . A-B. Lasioglossum (Hemihalictus) spectrum sp. nov. C. L. (H.) speculinum (Cockerell, 1925). D. L. (H.) sphecodicolor Sakagami \& Tadauchi, 1995. E. L. (H.) subsimplicior sp. nov. F. L. (H.) taeniolellum (Vachal, 1903). Scale bars: $1 \mathrm{~mm}$. 


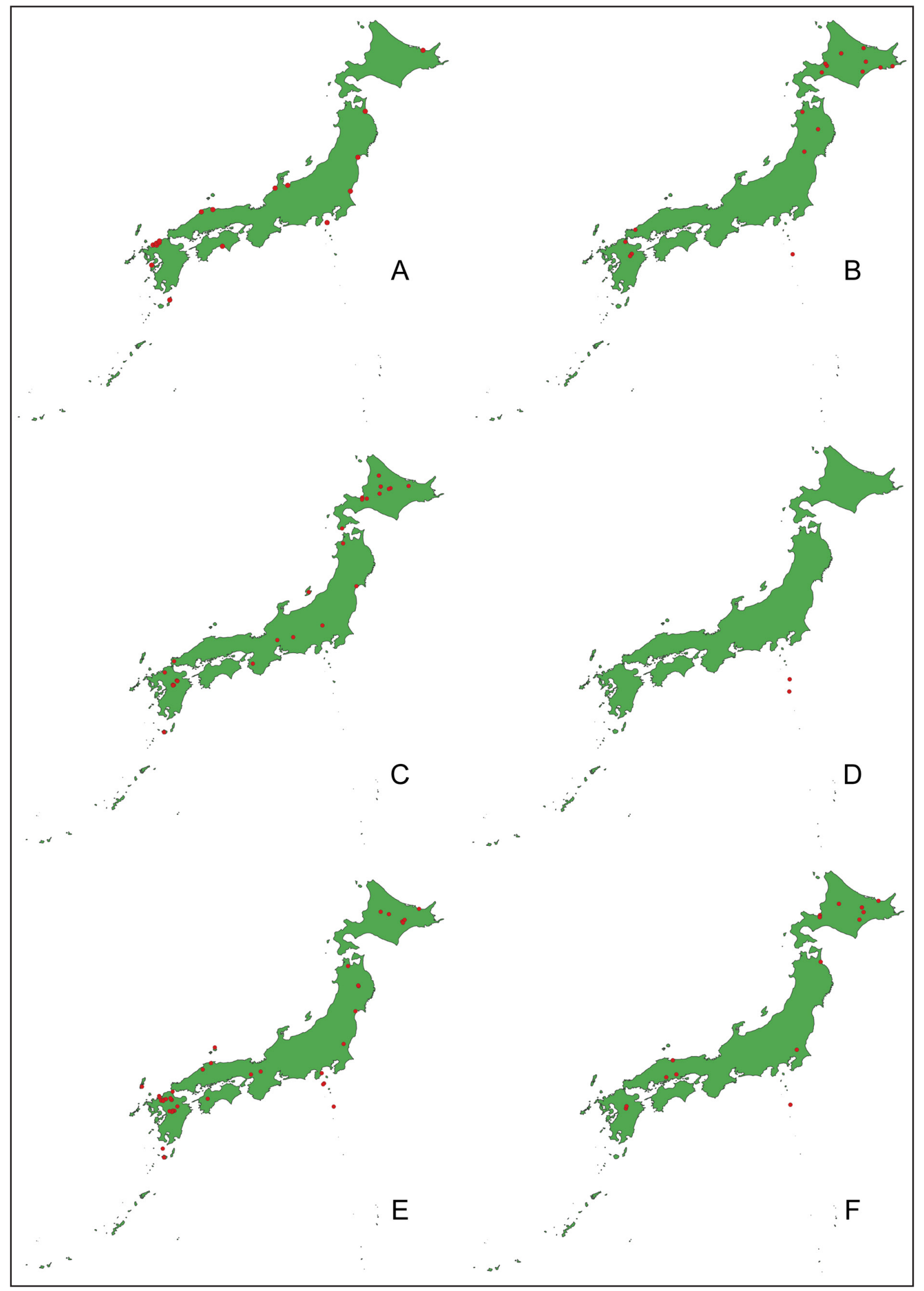

Fig. 17. Distribution maps. A. Lasioglossum (Hemihalictus) frigidum Sakagami \& Ebmer, 1996. B. L. (H.) kiautschouense (Strand, 1910). C. L. (H.) ohei Hirashima \& Sakagami, 1966. D. L. (H.) simplicior (Cockerell, 1931). E. L. (H.) spectrum sp. nov. F. L. (H.) speculinum (Cockerell, 1925). 


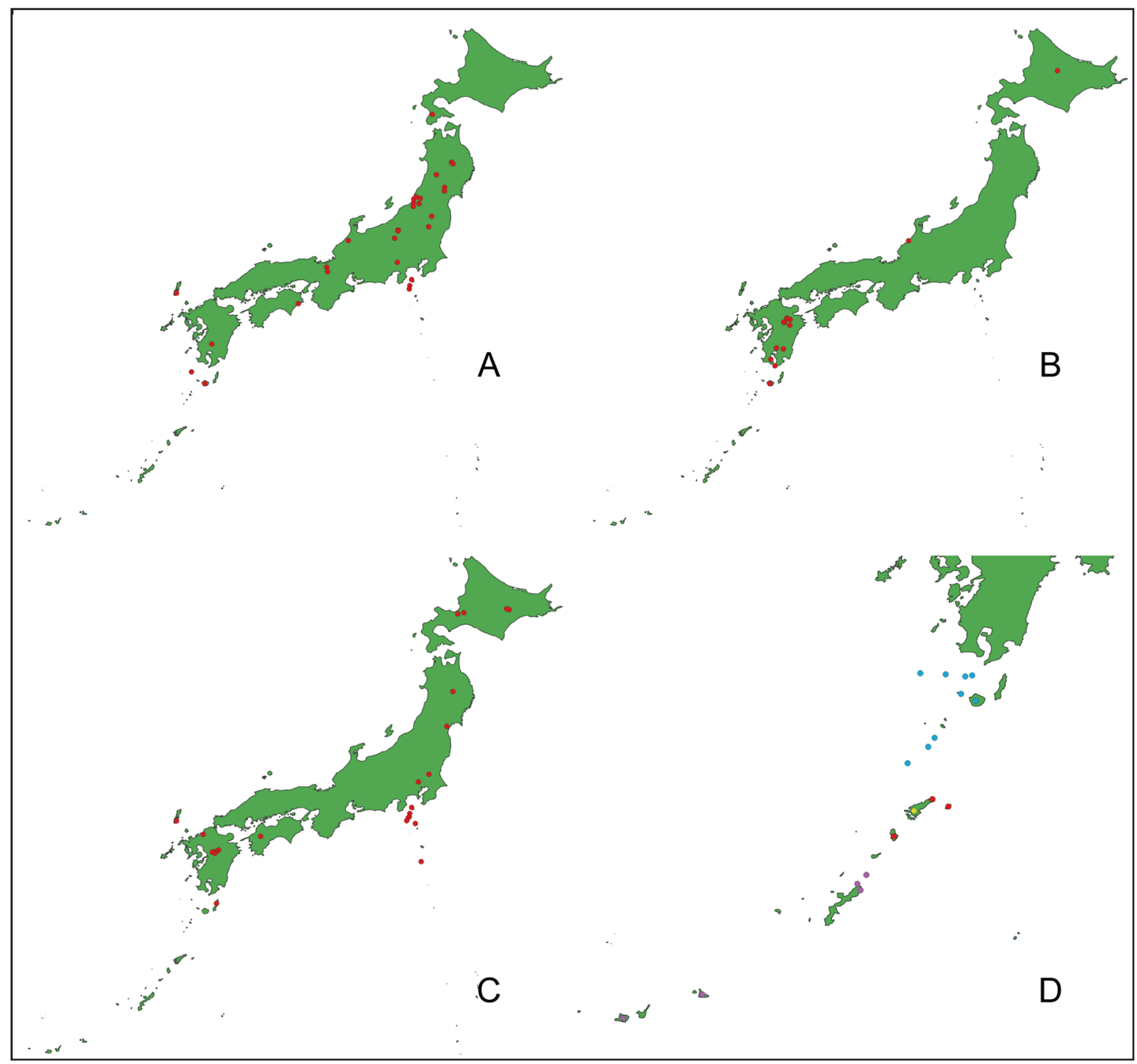

Fig. 18. Distribution maps. A. Lasioglossum (Hemihalictus) sphecodicolor Sakagami \& Tadauchi, 1995. B. L. (H.) subsimplicior sp. nov. C. L. (H.) taeniolellum (Vachal, 1903). D. L. (H.) amamiense Ebmer \& Sakagami, 1994 (red circle), L. (H.) ikudomei sp. nov. (purple circle), L. (H.) smilodon Ebmer \& Sakagami, 1994 (light blue circle) and L. (H.) tadauchii Murao, 2012 (yellow circle). 


\section{Unknown species in Japan}

\section{Lasioglossum (Hemihalictus) sp.}

\section{Material examined}

JAPAN - Kyushu • 2 ; Fukuoka Pref., Soeda-machi, Kyushu Univ., Hikosan Exp. St.; 3328'48.746" N,

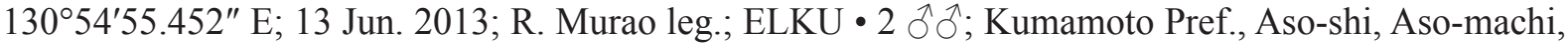
Matoishi wilderness; $37^{\circ} 27^{\prime} 15^{\prime \prime}$ N, 128 1'10" E; 5 Aug. 2013; R. Murao leg.; ELKU.

\section{Comments}

This unknown species has been identified as Lasioglossum (Hemihalictus) sexstrigatus (Schenck, 1869) in Japan. According to DNA analysis in the present study, the pair-wise sequence divergence between Japanese and European specimens was quite clear (7.3-7.9\% between L. sexstrigatus and $L$. sp. in Table 1). Morphologically, females of this species are slightly different from $L$. $(H$.) sexstrigatus as the mesoscutum has a weak tessellation over the entire surface (in contrast, in L. (H.) sexstrigatus, the mesoscutum is nearly smooth on the posterior half).

In the present study, I could not conclude that this unknown species is either undescribed or a known species, but this will be examined in further studies.
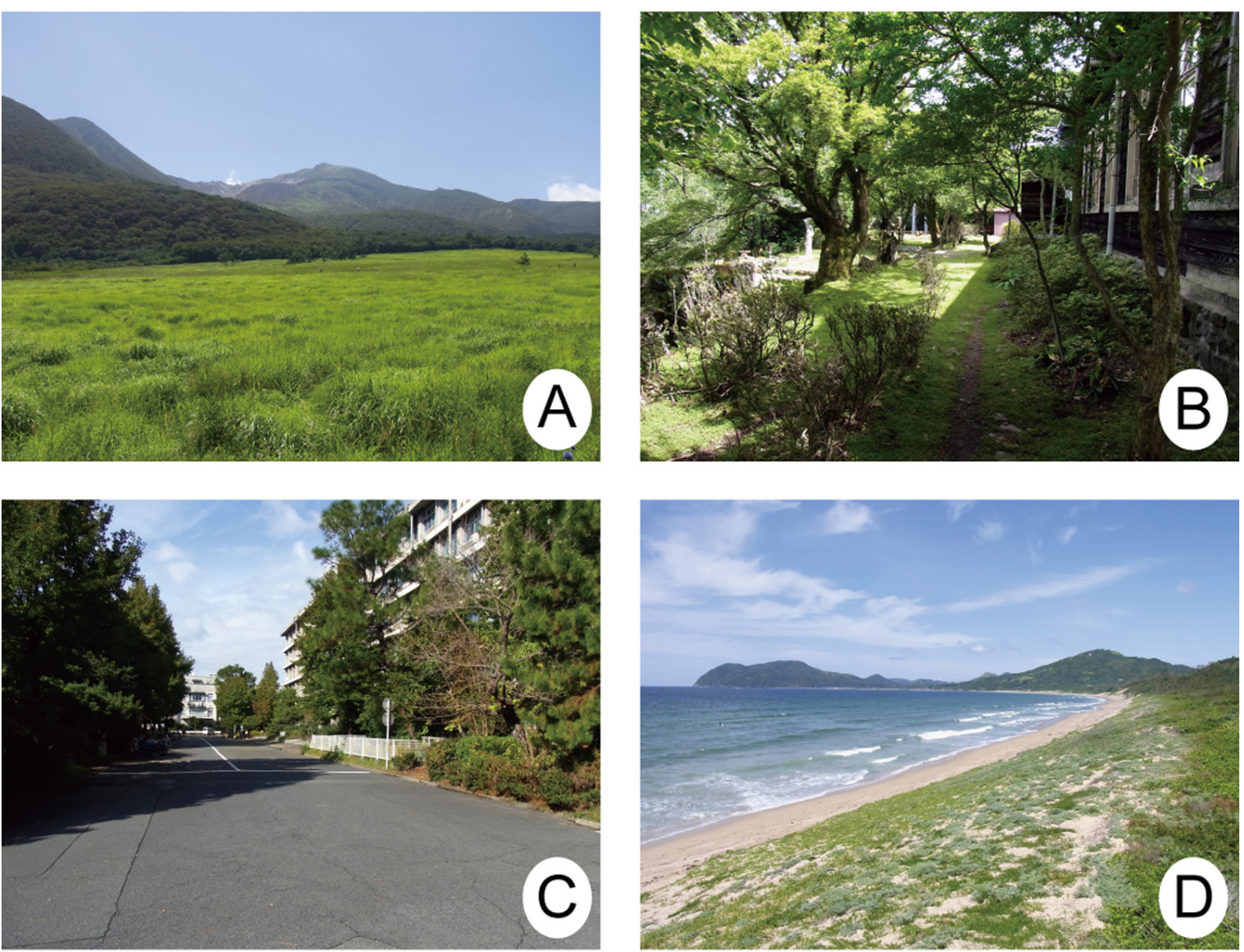

Fig. 19. Habitat in Japan. A. Chojyabaru, Kokonoe-machi, Kusu-gun, Oita Pref., Kyushu, Japan. B. Kyushu Univ., Hikosan Exp. St., Soeda-machi, Fukuoka Pref., Kyushu, Japan. C. Kyushu Univ., Hakozaki, Higashi-ku, Fukuoka-shi, Fukuoka Pref., Kyushu Japan. D. Nigino-hama, Itoshima-shi, Fukuoka Pref., Kyushu, Japan. 
Table 1. Inter- and intraspecific sequence divergences based on $395 \mathrm{bp}$ of the mtDNA COI gene among eight species belonging to the sexstrigatus group of Lasioglossum (Hemihalictus) Cockerell, 1897 (Kimura's two-parameter pairwise distances).

\begin{tabular}{|c|c|c|c|c|c|c|c|c|}
\hline Species & 1 & 2 & 3 & 4 & 5 & 6 & 7 & 8 \\
\hline \multicolumn{9}{|l|}{ 1. L. kiautshouense $(\mathrm{n}=1)$} \\
\hline 2. L. ohei $(\mathrm{n}=1)$ & 0.093 & & & & & & & \\
\hline 3. L. sexstrigatus $(\mathrm{n}=2)$ & 0.076 & 0.103 & 0 & & & & & \\
\hline 4. L. spectrum $(\mathrm{n}=3)$ & $0.085-0.088$ & $0.087-0.090$ & $0.064-0.067$ & $0-0.003$ & & & & \\
\hline 5. L. speculinum $(\mathrm{n}=2)$ & $0.053-0.055$ & $0.073-0.076$ & $0.082-0.085$ & $0.071-0.077$ & 0.003 & & & \\
\hline 6. L. sp. $(\mathrm{n}=4)$ & $0.082-0.088$ & $0.099-0.106$ & $0.073-0.079$ & $0.070-0.0790$ & $0.082-0.091$ & $0-0.005$ & & \\
\hline 7. L. subsimplicior $(\mathrm{n}=1)$ & 0.073 & 0.093 & 0.058 & $0.067-0.0700$ & $0.055-0.058$ & 0.085 & & \\
\hline 8. L. taeniolellum $(\mathrm{n}=2)$ & $0.084-0.087$ & $0.109-0.112$ & $0.109-0.112$ & $0.115-0.1220$ & $0.090-0.097$ & $0.109-0.115$ & $0.106-0.10$ & $90.004-0.008$ \\
\hline
\end{tabular}

\section{Key to species of the Lasioglossum (Hemihalictus) sexstrigatus group in Japan}

\section{Females}

1. Metasoma generally reddish over entire surface (Fig. 12A) Lasioglossum (Hemihalictus) sphecodicolor Sakagami \& Tadauchi, 1995

- Metasoma generally black over entire surface 2

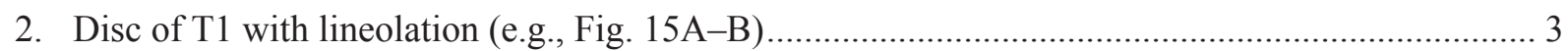

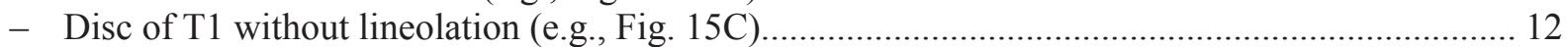

3. Lineolation of T1 nearly over entire surface (Fig. 15A, D-F) ..................................................... 4

- Lineolation of T1 over part of surface (Figs 15B, 16A-C, E) ...................................................... 7

4. Ridges of metapostnotum short, reaching anterior half (Fig. 9F) (distribution: northern to central Ryukyus)

L. (H.) smilodon Ebmer \& Sakagami, 1994

- Ridges of metapostnotum long, reaching posterior margin (Figs 4F, 7F, 8F) ............................... 5

5. IS of mesoscutum nearly smooth on posterior margin; T1 with silky dull luster

L. (H.) ohei Hirashima \& Sakagami, 1966

- IS of mesoscutum with distinct tessellation over entire surface; T1 with enamel-like luster 6

6. Head longer than wide or slightly longer than wide (HL/HW ratio $=1.02-1.07, n=5)$ (restricted to coastal sand dunes).....

L. (H.) frigidum Sakagami \& Ebmer, 1996

- Head wider than long or nearly as long as wide (HL/HW raito $=0.94-1.0, \mathrm{n}=5)$ (distribution: Izushotô Islands)

7. Ridges of metapostnotum short, reaching anterior half (Fig. 5F) (distribution: Ryukyus) .............. 8

- Ridges of metapostnotum long, reaching posterior margin or anterior $2 / 3$ (Figs $10 \mathrm{~F}, 11 \mathrm{E}, 13 \mathrm{E}) \ldots . .10$

8. Disc of T1 with sparse short hairs (Murao 2012: fig. 7)....... L. (H.) tadauchii Murao, 2012 (in part)

- Disc of T1 withtout distinct hairs (Fig. 15B)...

9. Disc of $\mathrm{T} 1$ with very weak lineolation on only basally

L. (H.) amamiense Ebmer \& Sakagami, 1994 (in part)

- Disc of T1 with very weak lineolation interrupted on medial area (Fig. 15B).. 
10. IS of mesoscutum medially to posteriorly smooth (Fig. 11D)

.L. (H.) speculinum (Cockerell, 1925)

- IS of mesoscutum medially to posteriorly tessellate (Figs 10E, 13D)

11. Metapostnotum dimly shiny, with distinct tessellation among ridges (Fig. 10F)

- Metapostnotum shinier, without distinct tessellation among ridges (Fig. 13E)

L. (H.) spectrum sp. nov.

L. (H.) subsimplicior sp. nov.

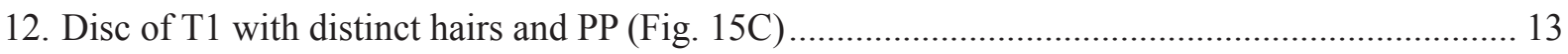

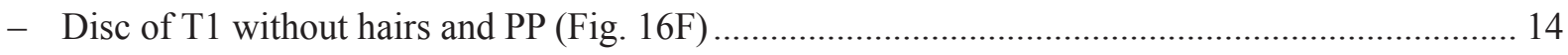

13. IS of mesoscutum medially to posteriorly nearly smooth (Fig. 6D)

.L. (H.) kiautschouense (Strand, 1910)

- IS of mesoscutum medially to posteriorly distinctly tessellate (Murao 2012: fig. 3) (distribution: central Ryukyus)

L. (H.) tadauchii Murao, 2012 (in part)

14. Distal process of labrum with horn-like lateral projection (Fig. 14D)

L. (H.) taeniolellum (Vachal, 1903)

- Distal process of labrum without lateral projection (e.g., Fig. 4D)

15. Ridges of metapostnotum short, reaching anterior half (Murao et al. 2010: fig. 1N) (distribution: central Ryukyus).

L. (H.) amamiense Ebmer \& Sakagami, 1994 (in part)

- Ridges of metapostnotum long, reaching posterior margin L. $(\boldsymbol{H}$.) sp.

\section{Males}

1. Metasoma generally reddish over entire surface as in female (Fig. 12A)

Lasioglossum (Hemihalictus) sphecodicolor Sakagami \& Tadauchi, 1995

- Metasoma generally black over entire surface

2. Clypeus nearly black, without distinct yellow spot on lower half (Figs 5C, 9C) ........................... 3

- Clypeus with a distinct yellow spot on lower half (Figs 4C, 7C, 8C, 10C, 14C) ............................ 4

3. F2 long, over $1.5 \times \mathrm{F} 1$

L. (H.) ikudomei sp. nov.

- F2 short, under $1.5 \times \mathrm{F} 1$ L. (H.) amamiense Ebmer \& Sakagami, 1994 and L. (H.) smilodon Ebmer \& Sakagami, 1994 (species with allopatric distributions)

4. F2 long, over $1.5 \times \mathrm{F} 1$

- F2 short, approximately or under $1.5 \times \mathrm{F} 1$. 6

5. Head wider than long, HL/HW ratio 0.90-0.96 L. (H.) taeniolellum (Vachal, 1903)

- Head longer than wide, HL/HW ratio 1.04-1.07 (restricted to coastal sand dunes)

L. (H.) frigidum Sakagami \& Ebmer, 1996

6. F2 nearly as long as F1; labrum without basal elevation.

.L. (H.) ohei Hirashima \& Sakagami, 1966

- F2 1.4-1.5 × F1; labrum with a distinct basal elevation (Fig. 2B)

L. (H.) simplicior (Cockerell, 1931), L. (H.) spectrum sp. nov., and $\boldsymbol{L}$. (H.) sp. 

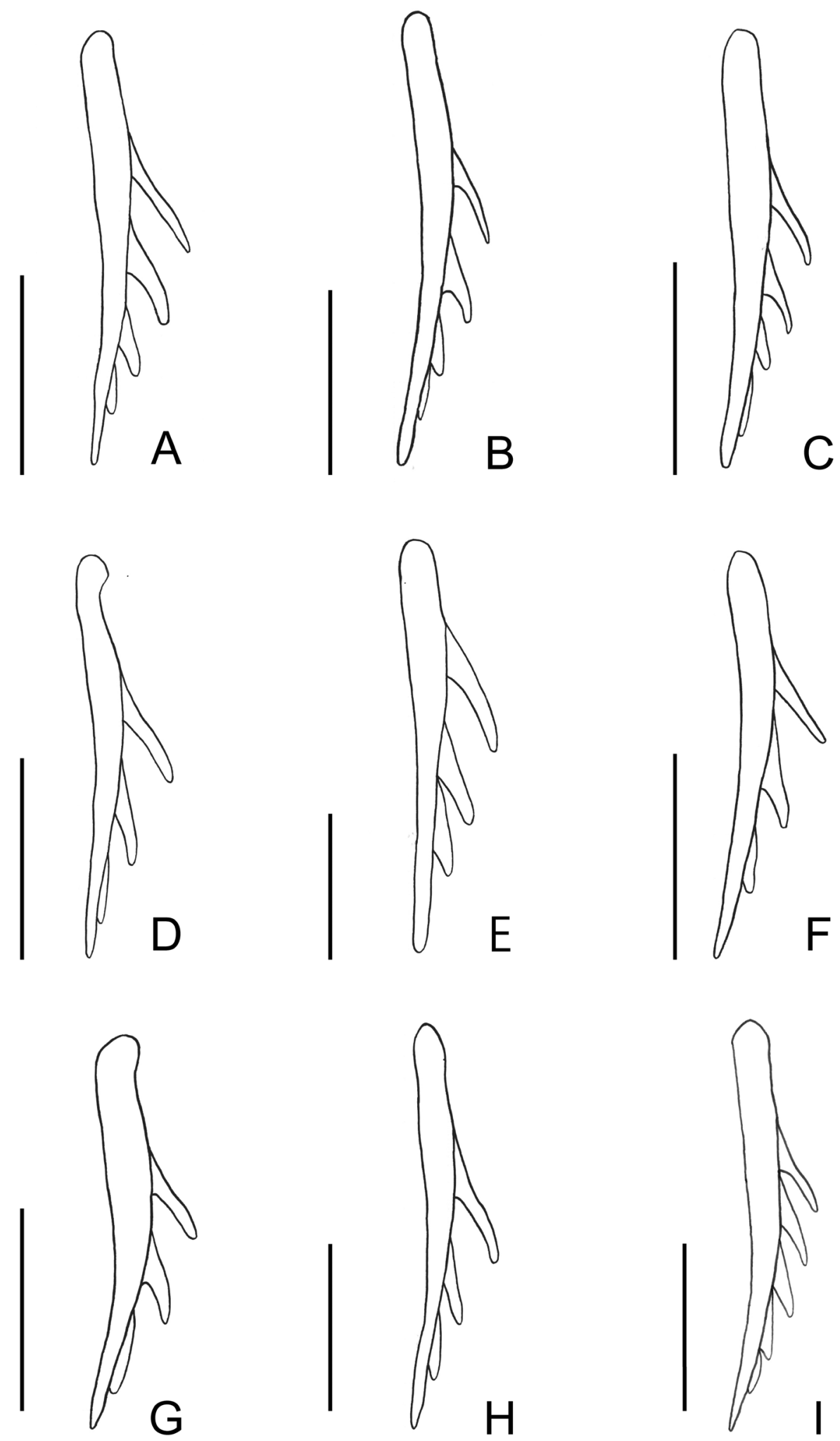

Fig. 20. Female inner hind tibial spur. A. Lasioglossum (Hemihalictus) frigidum Sakagami \& Ebmer, 1996. B. L. (H.) ikudomei sp. nov. C. L. (H.) kiautschouense (Strand, 1910). D. L. (H.) ohei Hirashima \& Sakagami, 1966. E. L. (H.) smilodon Ebmer \& Sakagami, 1994. F. L. (H.) spectrum sp. nov. G. L. (H.) speculinum (Cockerell, 1925). H. L. (H.) sphecodicolor Sakagami \& Tadauchi, 1995. I. L. (H.) taeniolellum (Vachal, 1903). Scale bars: $0.2 \mathrm{~mm}$. 


\section{Discussion}

The morphological differences among species of the sexstrigatus group often depend on subtle characteristics such as the sculpture of the mesoscutum or T1 and the length of metapostnotal ridges, etc., as described in the diagnosis of each species and the above Key. These characteristics are useful only in female specimens. Generally, in Lasioglossum, the interspecific differences are clearer in males than in the female, particularly using male genitalia. However, the interspecific differences in males of the sexstrigatus group is unclear even when comparing male genitalia. In addition, it is even more difficult to identify the species, owing to the male cephalic polymorphism. Among the European Lasioglossum, L. (H.) pleurospeculum Herrmann, 2001, L. (H.) sabulosum (Warncke, 1986), and L. (H.) sexstrigatus belong to the sexstrigatus group (Herrmann \& Doczkal 1999; Herrmann 2001). According to Herrmann \& Doczkal (1999) and Herrmann (2001), the tooth of the inner hind tibial spur in females is one of the useful characters that distinguishes $L$. $(H$.) sexstrigatus and the other two species: short teeth in $L$. (H.) sexstrigatus, long teeth in $L$. (H.) pleurospeculum and $L$. (H.) sabulosum. However, for the Japanese species, there is no interspecific difference in the female inner hind tibial spur (Fig. 20). In the present study, I examined part of the DNA barcoding region of the cytochrome oxidase subunit I gene of mitochondrial DNA gene for some species of the sexstrigatus group. The interspecies sequence divergences were larger than intraspecies divergences as in Table 1. Thus, DNA barcodes are quite useful in judging the interspecific differences in the sexstrigatus group. The sexstrigatus group is diverse in eastern Asia, and its diversity is unclear in the Oriental Region. Accumulation and utilisation of DNA data will be a very effective tool in the progress of taxonomic study of the sexstrigatus group in the Oriental Region.

\section{Acknowledgments}

I would like to express my thanks to Dr Yulia Astafurova (Zoological Institute, Russian Academy of Sciences, St Petersburg, Russia), Mr Fritz Gusenleitner (Biologiezentrum/Oberösterreichisches Landesmuseum, Linz, Austria), Mr Maximilian Schwarz (Linz, Austria), Mr Andreas Werner Ebmer (Puchenau, Austria), Dr Andreas Taeger (Senckenberg Deutsches Entomologisches Institut, Müncheberg, Germany), Mr Andrew Liston (Senckenberg Deutsches Entomologisches Institut, Müncheberg, Germany) and Dr Frank Koch (Museum für Naturkunde an der Humboldt Universität zu Berlin, Germany) for their help in my examining their Palaearctic and Oriental Lasioglossum collections. I would especially like to thank Prof. Emeritus Dr Osamu Tadauchi (Fukuoka, Japan), Prof. Emeritus Dr Yasuo Maeta (Shimane, Japan), Mr Katsuo Gôukon (Miyagi, Japan), Dr Shuichi Ikudome (Kagoshima Women's College, Japan), Dr Ryoichi Miyanaga (Shimane University, Japan), Dr Toshiharu Mita (Kyushu University, Japan), and Mr Makio Iwata (Kumamoto, Japan), Mr Keiichi Otsui (Fukuoka, Japan) for the loan of valuable specimens and literature. I also thank Editage (www.editage.com) for the English language editing. This research was supported by the JSPS Institutional Program for Young Researcher Overseas Visits.

\section{References}

Ascher J.S. \& Pickering J. 2020. Discover Life Bee Species Guide and World Checklist (Hymenoptera: Apoidea: Anthophila).

Available from http://www.discoverlife.org/mp/20q?guide=Apoidea_species [accessed 26 Apr. 2020].

Blüthgen P. 1922. Beiträge zur Synonymie der Bienengattung Halictus Latr. I. (Hym. Apid.). Deutsche Entomologische Zeitschrift 1922: 46-66.

Blüthgen P. 1925. Beiträge zur Kenntnis der Bienengattung Halictus Latr. II. Archiv für Naturgeschichte Abt. A 90: 86-136.

Blüthgen P. 1934. Schwedisch-chinesische wissenschaftliche Expedition nach den nordwestlichen Provinzen Chinas unter Leitung von Dr. Sven Hedin und Prof. Sü Ping-chang: Insekten, gesammelt vom 
schwedischen Arzt der Expedition Dr. David Hummel 1927-1930. 27 Hymenoptera. 5. Halictus- und Sphecodes-Arten (Hym.; Apidae; Halictini). Arkiv för Zoologi 27A: 1-23.

Cameron P. 1898. Hymenoptera Orientalia, or contributions to a knowledge of the Hymenoptera of the Oriental zoological region, Part VII. Memoirs and Proceedings of the Manchester Literary \& Philosophical Society 42: 1-84.

Cockerell T.D.A. 1897. On the generic position of some bees hitherto referred to Panurgus and Calliopsis. Canadian Entomologist 29: 287-290.

Cockerell T.D.A. 1898. Another yellow Perdita. Entomological News 9: 215-216.

Cockerell T.D.A. 1925. Some halictine bees from the Maritime Province of Siberia. Proceedings of the United States National Museum 68: 1-12.

Cockerell T.D.A. 1931. Bees collected by the reverend O. Piel in China. American Museum Novitates 466: $1-16$.

Danforth B.N., Minckley R.L. \& Neff J.L. 2019. The Solitary Bees: Biology, Evolution, Conservation. Princeton University Press, Princeton \& Oxford. https://doi.org/10.1515/9780691189321

Ebmer A.W. 1975. Neue westpaläarktische Halictidae. (Halictinae, Apoidea). Teil III. Linzer biologische Beiträge 7: 41-118.

Ebmer A.W. 1976. Liste der mitteleuropäischen Halictus- und Lasioglossum-Arten. Linzer biologische Beiträge 8: 393-405.

Ebmer A.W. 1978a. Die Halictidae der Mandschurei (Apoidea, Hymenoptera). Bonner Zoologische Beiträge 29: 183-221.

Ebmer A.W. 1978b. Die Bienen der Gattungen Halictus Latr., Lasioglossum Curt. und Dufourea Lep. (Hymenoptera, Halictidae) aus Korea. Annales Historico-naturales Musei Nationalis Hungarici 70: 307-319.

Ebmer A.W. 1980. Asiatische Halictidae (Apoidea, Hymenoptera). Linzer biologische Beiträge 12: 469-506.

Ebmer A.W. 1986. Die Artgruppe des Lasioglossum strictifrons (Vachal 1895) mit einer Bestimmungstabelle der Weibchen (Hymenoptera, Apoidea, Halictidae). Linzer biologische Beiträge 18: 417-443.

Ebmer A.W. 1996. Asiatische Halictidae, 5. Daten zur Aculeaten-Fauna der Ussuri-Region unter Berücksichtigung der angrenzenden Gebiete (Insecta: Hymenoptera: Apoidea: Halictidae: Halictinae). Linzer biologische Beiträge 28: 261-304.

Ebmer A.W. 1997. Asiatische Halictidae, 6. Lasioglossum carinaless-Evylaeus: Ergänzungen zu den Artengruppen von L. nitidiusculum and L. punctatissimum s. 1., sowie die Artengruppe des L. marginellum (Insecta: Hymenoptera: Apoidea: Halictidae: Halictinae). Linzer biologische Beiträge 29: 921-982.

Ebmer A.W. 2000. Asiatische Halictidae, 9. Die Artengruppe des Lasioglossum pauperatum (Insecta: Hymenoptera: Apoidea: Halictidae: Halictinae). Linzer biologische Beiträge 32: 399-453.

Ebmer A.W. 2006. Daten zur Aculeaten-Fauna der Ussuri-Region unter Berücksichtigung der angrenzenden Gebiete-2 Arten der Gattungen Halictus, Lasioglossum, Dufourea, Macropis aus dem Lazovski Zapovednik-Naturreservat Laso (Insecta: Hymenoptera: Apoidea: Halictidae, Melittidae). Linzer biologische Beiträge 38: 541-593. 
Ebmer A.W. \& Sakagami S.F. 1985. Taxonomic notes on the Palearctic species of the Lasioglossum nitidiusculum group, with description of L. allodalum sp. nov. (Hymenoptera, Halictidae). Kontŷu 53: 297-300.

Ebmer A.W., Maeta Y. \& Sakagami S.F. 1994. Six new halictine bee species from southwest archipelago, Japan (Hymenoptera, Halictidae). Bulletin of the Faculty of Agriculture, Shimane University 28: 23-36.

Friese H. 1918. Bienen aus Sumatra, Java, Malakka und Ceylon gesammelt von Herrn. Prof. Dr. V. Buttel-Reepen. Zoologische Jahrbücher 41: 489-520.

Fukasawa S. \& Miyano S. 2010. Fauna of the Aculeate Hymenoptera (Insecta) from the Izu Islands, Japan. Journal of the Natural History Museum and Institute, Chiba 11: 11-28. [In Japanese.]

Gibbs J., Packer L., Dumesh S. \& Danforth B.N. 2013. Revision and reclassification of Lasioglossum (Evylaeus), L. (Hemihalictus) and L. (Sphecodogastra) in eastern North America (Hymenoptera: Apoidea: Halictidae). Zootaxa 3672: 1-117. https://doi.org/10.11646/zootaxa.3672.1.1

Goloboff P.A., Farris J.S. \& Nixon K. 2008. TNT, a free program for phylogenetic analysis. Cladistics 24: 774-786. https://doi.org/10.1111/j.1096-0031.2008.00217.x

Goubara M. \& Maeta Y. 2002. Distributional records of sweat bees from Shikoku, Japan (Hymenoptera, Halictidae). Chugoku Kontyu 15: 27-29. [In Japanese.]

Goubara M., Sugimoto Y., Miyanaga R. \& Maeta Y. 2002. Some notes on the distributional records of sweat bees in Japan (Hymenoptera, Halictidae). Chugoku Kontyu 15: 31-37. [In Japanese.]

Goubara M., Sugimoto Y. \& Sugiura N. 2004. Discovery of 12 species of the genus Lasioglossum from Kyushu Island, Japan (Hymenoptera: Halictidae). Tsunekibachi 3: 51-58. [In Japanese.]

Gôukon K. 2006. Flower-visiting insects and their seasonal flunctuation at tideland and sand dune in Gamo Beach, Sendai, northern Japan. Chugoku Kontyu 20: 51-69. [In Japanese.]

Haneda Y. \& Tano T. 2003. The Aculeata Hymenoptera collected at Tsushima, Nagasaki Prefecture in May of 2003. Tsubekibachi 1: 8-22. [In Japanese.]

Herrmann M. 2001. Lasioglossum (Evylaeus) pleurospeculum spec. nov. - eine neue Furchenbienenart aus Mitteleuropa (Hymenoptera, Apidae). Linzer biologische Beiträge 33: 709-721.

Herrmann M. \& Doczkal D. 1999. Schlüssel zur Trennung der Zwillingsarten Lasioglossum sexstrigatus (Schenck, 1870) und Lasioglossum sabulosum (Warncke, 1986) (Hym., Apidae). Entomologische Nachrichten und Berichte 43: 33-40.

Hiraiwa K.H. \& Ushimaru A. 2017. Low functional diversity promotes niche changes in natural island pollinator communities. Proceedings of the Royal Society B 284: 20162218.

https://doi.org/10.1098/rspb.2016.2218

Hisamatsu M. 2011. Species composition of wild bees and their flower utilization in coastal sand dune vegetation at Ajigaura Beach, Ibaraki, central Japan. Japanese Journal of Environmental Entomology and Zoology 22: 23-32. [In Japanese.]

Hisamatsu M. 2017. Species composition of wild bees at Kataniwa, Kasama City, and comparison with other wild bee communities in Ibaraki Prefecture, central Japan. Japanese Journal of Environmental Entomology and Zoology 27: 121-131. [In Japanese.]

Hisamatsu M. \& Yamane S. 2006. Faunal makeup of wild bees and their flower utilization in a semiurbanized area in central Japan. Entomological Science 9: 137-145.

https://doi.org/10.1111/j.1479-8298.2006.00161.x 
MURAO R., Redifition and revision of the Lasioglossum sexstrigatus group in Japan

Ikudome S. 1995. Bee phenology in two areas of Miyazaki Prefecture, Mt. Wanitsuka and Sosanji village (Hymenoptera, Apoidea). In: Hirashima Y. (ed.) Contribution to the Fauna and Flora of Miyazaki Higashimorokata District-New Records and Observations of Noteworthy Insects, Spiders and Plants Based on Systematic and Biological Studies: 73 -96. Miyazaki Municipal University, Miyazaki.

Ikudome S. 2005. Ecological studies on the wild bee fauna in the rural area on Yaku-shima, Kagoshima Prefecture, Nippon (Hymenoptera, Apoidea). The Bulletin of Kagoshima Women's Junior College 40: $1-20$.

Ikudome S. \& Yamane S. 2009. Ants, wasps and bees of Take-shima, northern Ryukyus, Japan (Hymenoptera, Aculeata). Bulletin of the Institute, Minami-Kyushu Regional Science, Kagoshima Women's Junior College 25: 1-8.

Iwata M. 1997. A wild bee survey in Setaura (Kumamoto Pref.), Kyushu, Japan (Hymenoptera, Apoidea). Japanese Journal of Entomology 65: 635-662. [In Japanese.]

Kimura M. 1980. A simple method for estimating evolutionary rate of base substitutions through comparative studies of nucleotide sequences. Journal of Molecular Evolution 16: 111-120.

https://doi.org/10.1007/BF01731581

Maddison W.P. \& Maddison D.R. 2019. Mesquite: a modular system for evolutionary analysis. Version 3.61. Available from http://mesquiteproject.org [accessed 16 Jul. 2021].

Maeta Y. 2000. Biology and Conservation of the Andrenid Bee, Andrena (Calomelissa) prostomias Pérez in the Precincts of the Gakuonji Temple in Hyogo Prefecture. Kaiyusha, Tokyo. [In Japanese.]

Maeta Y., Miyanaga R. \& Kitamura K. 2003. Ecological studies on the wild bee fauna at Mt. Sanbe in Shimane Prefecture, Japan (Hymenoptera, Apoidea). New Entomologist 52: 19-47. [In Japanese.]

Michener C.D. 1993. The status of Prosopalictus, a halictine bee from Taiwan (Hymenoptera, Halictidae). Japanese Journal of Entomology 61: 67-72.

Michener C.D. 2007. The Bees of the World, $2^{\text {nd }}$ ed. The Johns Hopkins University Press, Baltimore and London.

Minagi K., Maeta Y. \& Kitamura K. 2000. Studies on the conservation of pollination ecosystem in sand dune 1. Pollinators and their seasonal fluctuation at the Taisha sand dune in San-in district. Bulletin of the Hoshizaki Green Foundation 4: 139-160. [In Japanese.]

Murao R. 2012. Lasioglossum (Evylaeus) tadauchii sp. nov. (Hymenoptera, Halictidae) from AmamiOshima, southwestern Japan. Esakia 52: 91-94.

Murao R. 2015. Notes on the distribution of the genus Lasioglossum (Hymenoptera, Halictidae) in eastern Asia. Japanese Journal of Systematic Entomology 21: 1-3.

Murao R. 2017a. Bees of the Hemihalictus series of Lasioglossum Curtis (Hymenoptera, Halictidae) in South Korea. Zootaxa 4268: 451-488. https://doi.org/10.11646/zootaxa.4268.4.1

Murao R. 2017b. First description of the males of both Lasioglossum bicornutum Murao, 2010 and $L$. latilabrum Murao \& Tadauchi, 2006 (Hymenoptera: Halictidae) occurring in the Ryukyu Islands, Japan. Japanese Journal of Systematic Entomology 23: 67-73.

Murao R. 2020. Genus Lasioglossum. In: Tadauchi O. (ed.) Catalogue of the Insects of Japan, Volume 9 Hymenoptera (Part 3. Apocrita, Aculeata): 299-310. The Entomological Society of Japan and Toukashobou, Fukuoka. [In Japanese.]

Murao R. \& Tadauchi O. 2007. A revision of the subgenus Evylaeus of the genus Lasioglossum in Japan (Hymenoptera, Halictidae) Part I. Esakia 47: 169-254. 
Murao R., Tadauchi O., Goubara M. \& Maeta Y. 2010. Taxonomy of the carinaless group of Lasioglossum (Evylaeus) (Hymenoptera, Halictidae) from the Ryukyu Islands, Japan, with description of seven new species. Zootaxa 2669: 1-33. https://doi.org/10.11646/zootaxa.2669.1.1

Murao R., Lee H.S. \& Tadauchi O. 2014. Lasioglossum (Acanthalictus) dybowskii (Hymenoptera, Halictidae) newly recorded from South Korea, with a checklist of the genus Lasioglossum in Korean Peninsula. Journal of Hymenoptera Research 38: 141-153. https://doi.org/10.3897/jhr.38.7572

Murao R., Lee H.S. \& Tadauchi O. 2015a. Bees of the Lasioglossum series (Hymenoptera, Halictidae) in South Korea, with an illustrated keys to species. Zootaxa 4044: 511-534.

https://doi.org/10.11646/zootaxa.4044.4.3

Murao R., Tadauchi O. \& Lee H.S. 2015b. Synopsis of Lasioglossum (Dialictus) Robertson, 1902 (Hymenotera, Apoidea, Halictidae) in Japan, the Korean Peninsula and Taiwan. European Journal of Taxonomy 137: 1-50. https://doi.org/10.5852/ejt.2015.137

Murao R., Tadauchi O. \& Miyanaga R. 2015c. The bee tribe Anthidiini (Hymenoptera, Megachilidae) collected from central Asia. Japanese Journal of Systematic Entomology 21: 7-12.

Negoro H. 2001a. A wild bee survey in the coastal zone of Shimao, Himi-shi, Toyama Prefecture, Hokuriku, Japan. Bulletin of the Toyama Science Museum 24: 43-51. [In Japanese.]

Negoro H. 2001b. Wild bee surveys in the farmland zone at Oyabe-shi and in the dry riverbed of Shogawa river at Daimon-machi, Toyama Prefecture, Hokuriku, Japan. Bulletin of the Toyama Science Museum 24: 53-65. [In Japanese.]

Nixon K.C. 2002. WinClada ver. 1.00.08. Published by the author, Ithaca, NY.

Pauly A. 1980. Descriptions préliminaires de quelques sous-genres afrotropicaux nouveaux dans la famille des Halictidae (Hymenoptera, Apoidea). Revue de Zoologie africaine 94: 119-125.

Pauly A. 1984. Classification des Halictidae de Madagascar et des îles voisines I. Halictinae (Hymenoptera, Apoidea). Verhandlungen der naturforschenden Gesellschaft in Basel 94: 121-156.

Pesenko Y.A. 2007a. Subgeneric classification of the Palaearctic bees of the genus Evylaeus Robertson (Hymenoptera: Halictidae). Zootaxa 1500: 1-54. https://doi.org/10.11646/zootaxa.1500.1.1

Pesenko Y.A. 2007b. A taxonomic study of the bee genus Evylaeus Robertson of Eastern Siberia and the Far East Russia (Hymenoptera: Halictidae). Zoosystematica Rossica 16: 79-123.

https://doi.org/10.31610/zsr/2007.16.1.79

QGIS Development Team. 2020. QGIS Geographic Information System. Open Source Geospatial Foundation Project. Available from http://qgis.osgeo.org [accessed 9 Aug. 2021].

Sakagami S.F. 1992. [Families and Societies of Bees.] Chuô-kôron-sha, Tokyo. [In Japanese.]

Sakagami S.F. \& Ebmer A.W. 1996. Lasioglossum (Evylaeus) frigidum sp. nov., with taxonomic notes on the allied species of $L$. (E.) sexstrigatus group (Hymenoptera, Apoidea, Halictidae). Linzer biologische Beiträge 28: 899-916.

Sakagami S.F. \& Michener C.D. 1962. The Nest Architecture of the Sweat Bees (Halictinae), a comparative Study. University of Kansas Press, Lawrence.

Sakagami S.F. \& Tadauchi O. 1995. Three new halictine bees from Japan (Hymenoptera, Apoidea). Esakia 35: 177-200.

Sakagami S.F., Hirashima Y. \& Ohè Y. 1966. Bionomics of two new Japanese halictine bees (Hymenoptera, Apoidea). Journal of the Faculty of Agriculture, Kyushu University 13: 673-703. https://doi.org/10.5109/22739 
MURAO R., Redifition and revision of the Lasioglossum sexstrigatus group in Japan

Sandhouse G.A. 1943. The type species of the genera and subgenera of bees. Proceedings of the United States National Museum 92: 516-519. https://doi.org/10.5479/si.00963801.3156.519

Schmidt S., Schmidt-Egger C., Morinière J., Haszprunar G. \& Hebert P. 2015. DNA barcoding largely supports 250 years of classical taxonomy: identifications for central European bees (Hymenoptera, Apoidea partim). Molecular Ecology Resources 15: 985-1000. https://doi.org/10.1111/1755-0998.12363

Smith F. 1873. Descriptions of aculeate Hymenoptera of Japan, collected by Mr. George Lewis at Nagasaki and Hiogo. Transactions of the Entomological Society of London 1873: 181-206. https://doi.org/10.1111/j.1365-2311.1873.tb00641.x

Strand E. 1910. Neue süd- und ostasiatische Halictus-Arten im kgl. zoologischen Museum zu Berlin. (Hym., Apidae). Berliner entomologische Zeitschrift 54: 179-211.

Strand E. 1913. H. Sauter's Formosa-Ausbeute. Apidae I (Hym.). Supplementa Entomologica 2: 23-67.

Tadauchi O. \& Murao R. (eds). 2014. An Illustrated Guide to Japanese Bees. Bunichi, Tokyo. [In Japanese.]

Takahashi H. \& Sakagami S.F. 1993. Notes on the halictine bees (Hymenoptera, Apoidea) of the Izu Islands: Lasioglossum kuroshio sp. nov., life cycles in Hachijo-jima Is., and a preliminary list of the species in the Izu Islands. Japanese Journal of Entomology 61: 267-278.

Tamura K., Peterson D., Peterson N., Stecher G., Nei M. \& Kumar S. 2011. MEGA5: Molecular evolutionary genetics analysis using maximum likelihood, evolutionary distance, and maximum parsimony methods. Molecular Biology and Evolution 28: 2731-2739.

https://doi.org/10.1093/molbev/msr121

Usui M., Nishijima Y., Fukuda H. \& Sakagami S.F. 1976. A wild bee survey in Obihiro Eastern Hokkaido. Reserch Bulletin of Obihiro University, Series I 10: 225-251.

Vachal J. 1903. Hyménoptères rapportés du Japon par M. Harmand. Mellifères. (Quatrième mémoire). Bulletin du Muséum national d'histoire naturelle 9 (3): 129-132.

Warncke K. 1975. Beitrag zur Systematik und Verbreitung der Furchenbienen in der Türkei (Hymenotera, Halictus). Polskie Pismo Entomologiczne 45: 81-123.

Warncke K. 1981. Beitrag zur Bienenfauna des Iran. 14. Die Gattung Halictus Latr., mit Bemerkungen über unbekannte und neue Halictus-Arten in der Westpaläarktis und Zentralasien. Bollettino del Museo Civico di Storia Naturale di Venezia 32: 67-166.

Yamane S. \& Ikudome S. 2008. Ants, wasps and bees of Kuro-shima, northern Ryukyus, Japan (Hymenoptera, Aculeata). Bulletin of the Institute, Minami-Kyushu Regional Science, Kagoshima Women's Junior College 24: 1-9.

Yonekura K. \& Kajita T. 2003-. BG Plants Japanese-scientific names index (Ylist). Available from http://ylist.info/ [accessed 11 Feb. 2020].

Manuscript received: 28 December 2020

Manuscript accepted: 21 June 2021

Published on: 18 August 2021

Topic editor: Nesrine Akkari

Section editor: Gavin Broad

Desk editor: Kristiaan Hoedemakers 
Printed versions of all papers are also deposited in the libraries of the institutes that are members of the EJT consortium: Muséum national d'histoire naturelle, Paris, France; Meise Botanic Garden, Belgium; Royal Museum for Central Africa, Tervuren, Belgium; Royal Belgian Institute of Natural Sciences, Brussels, Belgium; Natural History Museum of Denmark, Copenhagen, Denmark; Naturalis Biodiversity Center, Leiden, the Netherlands; Museo Nacional de Ciencias Naturales-CSIC, Madrid, Spain; Real Jardín Botánico de Madrid CSIC, Spain; Zoological Research Museum Alexander Koenig, Bonn, Germany; National Museum, Prague, Czech Republic. 


\section{Appendix 1}

Taxa scored for cladistic analysis.

\section{Ingroups}

1. Lasioglossum clypearis group: L. (H.) buccale (Pérez, 1903); L. (H.) punctatissimum (Schenck, 1853).

2. L. limbellus group: L. (H.) brevicorne (Schenck, 1870); L. (H.) limbellum (Morawitz, 1876).

3. L. longirostre group: L. (H.) longirostre (Morawitz, 1876).

4. L. marginellum group: L. (H.) peregrinum (Blüthgen, 1923); L. (H.) subaenescens (Pérez, 1895).

5. L. nitidiusculum group: L. (H.) allodalum Ebmer \& Sakagami, 1985; L. (H.) rufitarse (Zetterstedt, 1838).

6. L. pauperatum group: L. (H.) pauperatum (Brullé, 1832); L. (H.) transitorium (Schenck, 1870).

7. L. semilucens group: L. (H.) kuroshio Takahashi \& Sakagami, 1993; L. (H.) lucidulum (Schenck, 1861); L. (H.) metis Ebmer, 2002; L. (H.) minutissimum (Kirby, 1802); L. (H.) pumilum Sakagami \& Tadauchi, 1995; L. (H.) quadrinotatulum (Schenck, 1861); L. (H.) sakagamii Ebmer, 1978; L. (H.) sulcatulum longifacies Sakagami \& Tadauchi, 1995; L. (H.) transpositum (Cockerell, 1925); L. (H.) zunaga Sakagami \& Tadauchi, 1995.

8. L. sexstrigatus group: L. (H.) amamiense Ebmer \& Sakagami, 1994; L.(H.) bicornutum Murao, 2010; L. (H.) canaliculatum Murao, 2010; L. (H.) donanense Murao, 2010; L. (H.) frigidum Sakagami \& Ebmer, 1996; L. (H.) japonicum (Dalla Torre, 1896); L. (H.) ohei Hirashima \& Sakagami, 1966; L. (H.) sexstrigatus (Schenck, 1869); L. (H.) simplicior (Cockerell, 1931); L. (H.) smilodon Ebmer \& Sakagami, 1994; L. (H.) spectrum Murao sp. nov.; L. (H.) sphecodicolor Sakagami \& Tadauchi, 1995; L. (H.) taeniolellum (Vachal, 1903); L. (H.) urumaense Murao, 2010; L. (H.) yonaguniense Murao, 2010; L. (H.) zipangu Ebmer \& Sakagami, 1994.

9. L. villosulum group: L. (H.) villosulum (Kirby, 1802); L. (H.) truncaticolle (Morawitz, 1877).

10. L. alphenum group (= L. $($ Sudila)): L. (H.) alphenum (Cameron, 1897), L. (H.) aulacophorum (Strand, 1913), L. (H.) bidentatum (Cameron, 1898).

\section{Outgroup}

Dialictus: L. (D.) aeratum (Kirby, 1802); L. (D.) leucopus (Kirby, 1802). 


\section{Appendix 2}

Characters scored for cladistic analysis.

\section{Color}

1. Body color: (0) black, (1) metallic green.

\section{Head}

2. Head length / width ratio in female: (0) under 0.95 , (1) $0.96-1.09$, (2) over 1.10 , (3) over 1.50.

3. Genal process of male head: (0) present as variation, (1) absent.

4. Yellow spot on male clypeus: (0) present and distinct, (1) present, but indistinct, (2) absent.

5. Supraclypeus: (0) nearly flat, (1) distinctly swelled.

6. Shape of male clypeus: (0) normal, (1) extremerely long, (2) incurved on lower margin, (3) bidentate as variation.

7. Malar area: (0) linear, (1) distinctly longer than wide.

8. Length of male antenna: (0) long, attaining to metasoma, (1) short, not attaining to metasoma.

9. F1:F2 in male: (0) F2 1.3-1.6 F F1, (1) F2 1.7-2.0 × F1, (2) F2 as long as F1.

10. Color of male labrum: (0) black, (1) yellow.

11. Basal elevation of male labrum: (0) present, not depressed centrally, (1) present, depressed centrally, (2) absent.

12. Distal process of female labrum: (0) narrow, (1) moderately broad.

13. Distal process of male labrum: (0) present, (1) absent.

\section{Mesosoma}

14. Mesepisternum tubercle: (0) present, (1) absent.

15. Oblique carina of propodeum: (0) present, (1) absent.

16. Hairs on posterior surface of propodeum: (0) sparse, (1) dense and tomentose.

17. Coxa in male: (0) normal, (1) modified.

18. Basitibial plate of hind leg in male: (0) present with weak carina marginally, (1) absent.

19. Inner hind tibial spur in male: (0) serrate, (1) dentate.

\section{Metasoma}

20. Color: (0) black, (1) reddish.

21. Apical fimbriae on female metasomal terga: (0) present, (1) absent. 
22. Hairs on male metasomal sterna: (0) normal, without hair tuft, (1) present, with thin hair tuft on S4-S5, (2) present, with thin hair tuft on S3-S5.

23. Median process of male S8: (0) present, well developed (over S7), (1) present, less developed (not over S7), (2) absent.

\section{Male genitalia}

24. Gonobase ventral arm: (0) connected, (1) not connected.

25. Sculpture of gonocoxite: (0) smooth, (1) lineolate or reticulate.

26. Shape of gonostylus: (0) small and bud-like, (1) small and elongate, (2) large and rounded.

27. Gonostylus hairs: (0) simple, (1) simple, mixed with fine branched hairs.

28. Length of ventral retrorse lobe: (0) long, attaining to gonobase, (1) short or moderately long, not attaining to gonobase.

29. Sculpture of ventral retrorse lobe: (0) smooth, (1) lineolate.

30. Ventral retrorse lobe hairs: (0) sparse to dense short hairs over entire surface, (1) a few short hairs, (2) moderately dense setae apically.

31. Angle of penis valve in lateral view: (0) gently curved, (1) angulate.

32. Cleft of penis valve: (0) present, (1) absent. 


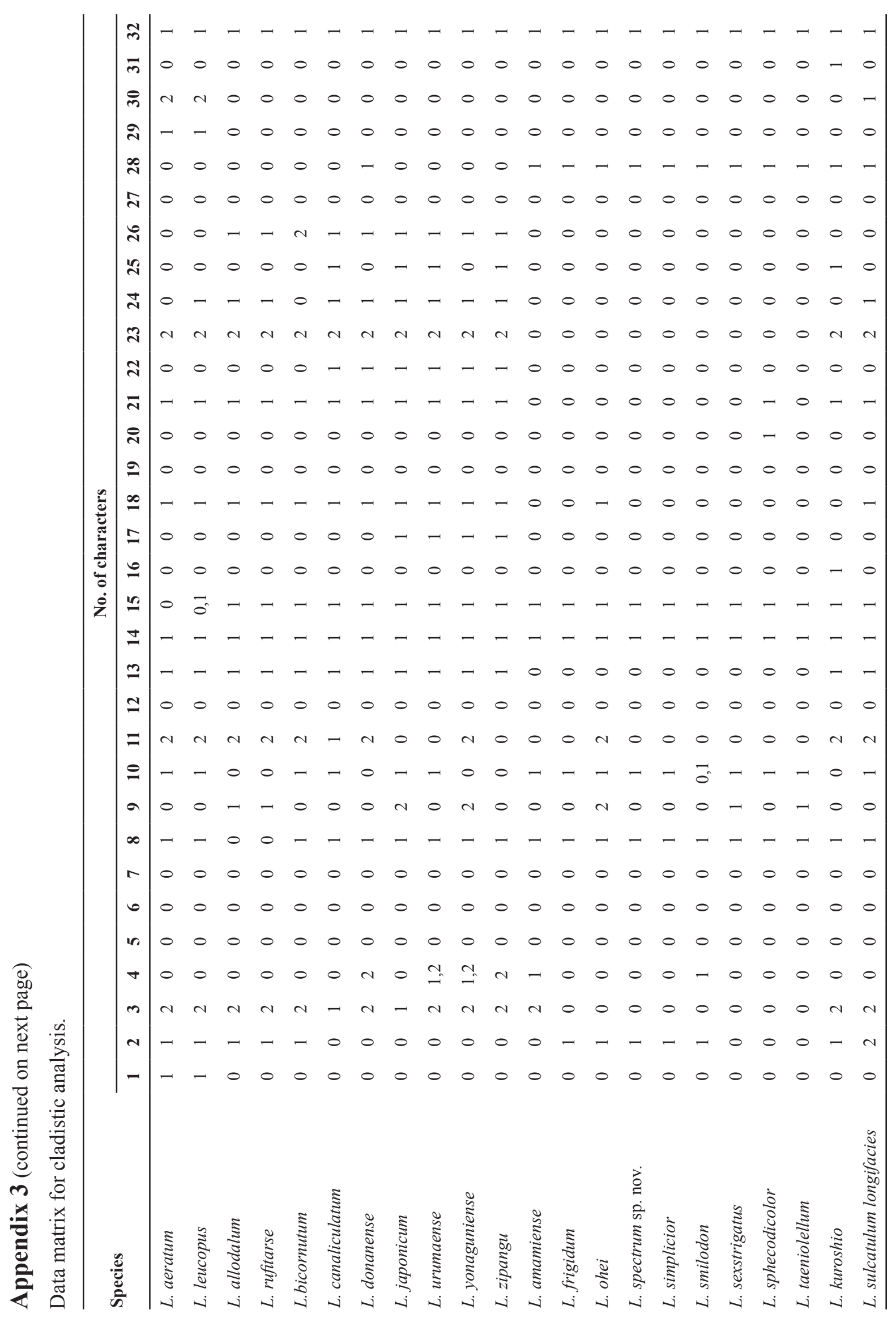




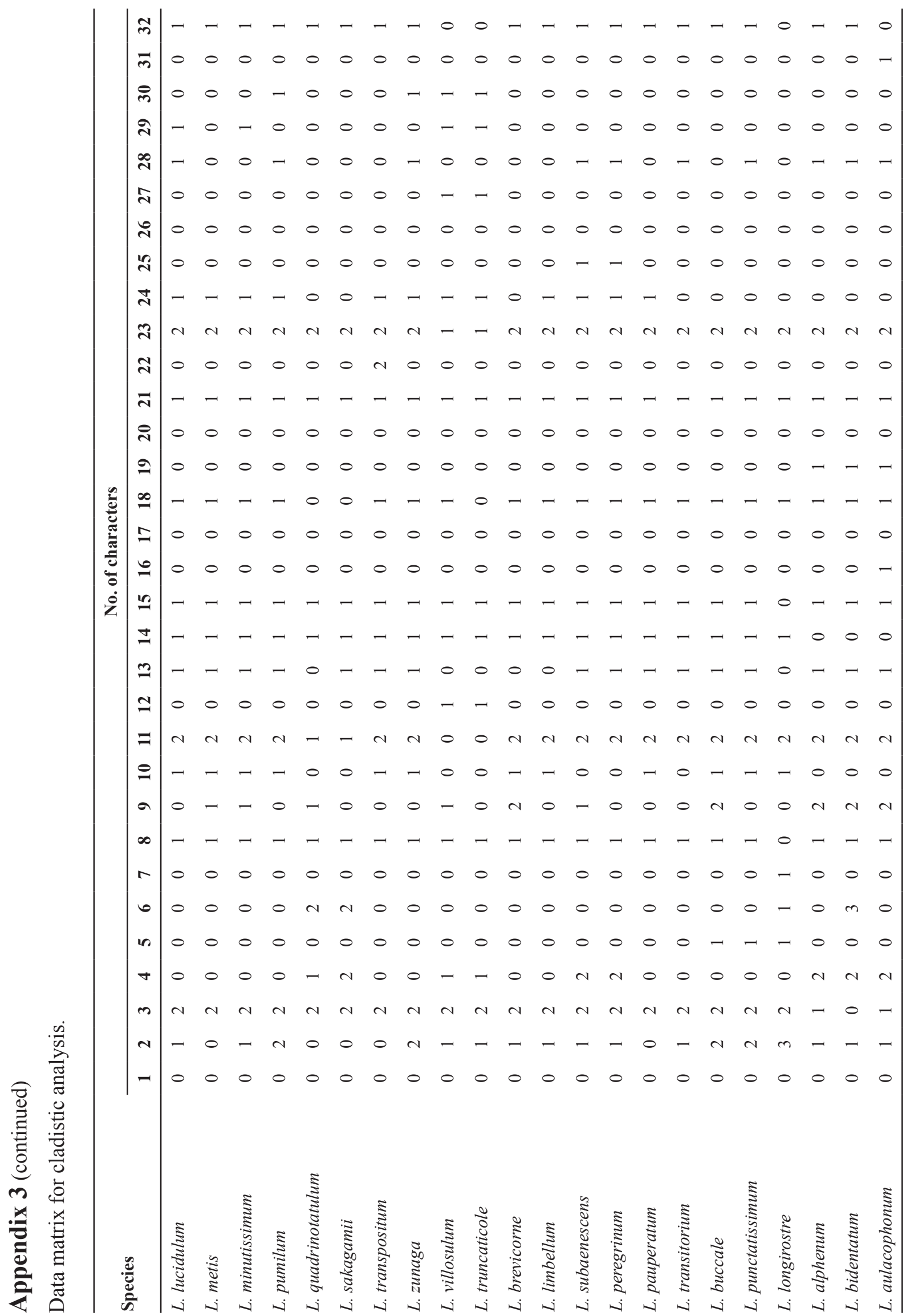




\section{Appendix 4}

List of species of Lasioglossum Cockerell, 1897 used in the DNA analysis.

\begin{tabular}{|c|c|c|c|c|}
\hline Species & $\begin{array}{l}\text { Genbank } \\
\text { accession no. }\end{array}$ & $\begin{array}{l}\text { Lengh } \\
\text { (bp) }\end{array}$ & Collection site & References \\
\hline L. kiautschouense & LC0580416 & 703 & Ashoro, Hokkaido, Japan & Present study \\
\hline L. occidens & LC043129 & 675 & $\begin{array}{l}\text { Gangwon-do, } \\
\text { South Korea }\end{array}$ & Murao et al. (2015a) \\
\hline L. ohei & LC0580417 & 648 & $\begin{array}{l}\text { Chojyabaru, } \\
\text { Oita, Japan }\end{array}$ & Present study \\
\hline L. sexstrigatus & HQ954761 & 616 & Bavaria, Germany & Schmidt et al. (2015) \\
\hline L. sexstrigatus & HQ954762 & 612 & Bavaria, Germany & Schmidt et al. (2015) \\
\hline L. spectrum sp. nov. & LC0580418 & 707 & $\begin{array}{l}\text { Shikanoshima, } \\
\text { Fukuoka, Japan }\end{array}$ & Present study \\
\hline L. spectrum sp. nov. & LC0580419 & 707 & $\begin{array}{l}\text { Mt Hiko-san, } \\
\text { Fukuoka, Japan }\end{array}$ & Present study \\
\hline L. spectrum sp. nov. & LC0580420 & 708 & $\begin{array}{l}\text { Mt Hiko-san, } \\
\text { Fukuoka, Japan }\end{array}$ & Present study \\
\hline L. speculinum & LC0580421 & 599 & Ashoro, Hokkaido, Japan & Present study \\
\hline L. speculinum & LC0580422 & 634 & $\begin{array}{l}\text { Honbetsu, } \\
\text { Hokkaido, Japan }\end{array}$ & Present study \\
\hline $\begin{array}{l}\text { L. subsimplicior } \\
\text { sp. nov. }\end{array}$ & LC0580423 & 679 & $\begin{array}{l}\text { Handa-kogen, } \\
\text { Oita, Japan }\end{array}$ & Present study \\
\hline L. taeniolellum & LC0580424 & 689 & $\begin{array}{l}\text { Ashoro, } \\
\text { Hokkaido, Japan }\end{array}$ & Present study \\
\hline L. taeniolellum & LC0580425 & 695 & $\begin{array}{l}\text { Kyushu Univ., } \\
\text { Hakozaki, Fukuoka, Japan }\end{array}$ & Present study \\
\hline L. sp. & LC0580426 & 707 & $\begin{array}{l}\text { Mt Hiko-san, } \\
\text { Fukuoka, Japan }\end{array}$ & Present study \\
\hline$L$. sp. & LC0580427 & 707 & $\begin{array}{l}\text { Mt Hiko-san, } \\
\text { Fukuoka, Japan }\end{array}$ & Present study \\
\hline L. sp. & LC0580428 & 563 & $\begin{array}{l}\text { Aso, Kumamoto, } \\
\text { Japan }\end{array}$ & Present study \\
\hline$L . \mathrm{sp}$. & LC0580429 & 692 & $\begin{array}{l}\text { Aso, Kumamoto, } \\
\text { Japan }\end{array}$ & Present study \\
\hline
\end{tabular}

